\title{
Household Size and Women Empowerment
}

\author{
Jeenat Binta Jabbar \\ RMIT University
}

Women's empowerment is a major concern in the developing world and an integral part of the UN's Sustainable Development Goals. Women's empowerment can be significantly affected, both positive and negative, by other household member's decision to migrate. This study explores the consequences of migration for left-behind women in Bangladesh. This study examines the way that women's bargaining power within household is affected, whether positive or negatively, by the migration of other household members. To test this hypothesis, this study presents empirical model that analyses women's empowerment in rural Bangladesh with data from 2011-12 and 2015. I adopt multidimensional measures of empowerment encompassing violence, mobility restrictions, production activities, income, and leadership. The study finds significant evidence that migration of a member decreases some constraints of mobility, and decisionmaking for production activities. The results infer that migration leads to improvements in bargaining power of left-behind women. My findings are also robust to various specifications and hold when empowerment is measured in various ways.

Keywords: empowerment, women, migration, household bargaining, Bangladesh

\section{INTRODUCTION}

Women's equality and empowerment are integral to all dimensions of inclusive and sustainable development and, as such, are embedded into the Sustainable Development Goals (UN Women, 2018). Empowerment does not necessarily entail having possession of resources, but it is a process by which someone acquires the authority or power to make decisions over the use of those resources (Kabeer, 1999). The ability to exercise can take the form of bargaining and negotiation within the household from the extent to which decision-making outcomes varied among household members (ibid). Women's conditions and reinforcing gendered roles are determined both at the societal and household level (Momsen, 2003). Consequently, changes in the structure of the family unit can potentially lead to changes in levels of women's empowerment.

It is well-understood that women's empowerment can be seen through various ways within household; for example, women will have control and say over contraceptive use and fertility (Balk 1994; Morgan and Niraula 1995; Schuler et al. 1997). However, women's empowerment could also be affected by household size. With the physical absence of a member of household, females become more autonomous in decisionmaking or face more constraints because of added responsibilities. Many studies suggest that migration affects women's empowerment by changing household size which ultimately brings changes in constraints of women's relative bargaining power over income, resources and remittances (Hassan and Jebin 2019; Ullah 2017; Talyor and Mora 2006). The paper attempts empirically to assess this mechanism, which has 
been less concerned for testing formally in the economics literature. Thus, the aim of this paper is to test this proposition by looking at the effect of changes in household size by migration of a household member on the empowerment of left-behind women.

In previous economic studies, women empowerment has been looked in various aspects. Economic empowerment along with decision-making ability, owner of assets, and access to household incomes are the prominent indicators used in the literature related to women's empowerment (Goetz and Gupta 1996; Kabeer 2001; Mahmud et al. 2012). There are ample of literature deal with a wide array of indicators of empowerment, but limited studies choose multidimensional approach to aggregate indicator for indices. This study has chosen the indicators of empowerment largely based on multidimensional approach to draw a more holistic overview.

The study begins with a conceptual understanding of the dynamics which suggests that women's empowerment changes ambiguously depending on household structure. Second, the study uses Bangladeshi household data to test this proposition. I employ two waves of the Bangladesh Integrated Household Survey (BIHS) $(2011-12$; 2015) dataset. Bangladesh gives an appropriate setting for this study because it is one of the major labour-sending countries in the world. More than 12 million Bangladeshis have migrated internationally since 1976, with over half a million leaving the country in 2018 alone (BMET, 2019). Due to costs associated with migration as well as available opportunities in destination countries, often migrants leave their family behind, particularly women (Alonso, 2011).

For the indicators of women empowerment, this study has mostly taken the data from the module of Women's Empowerment in Agriculture Index (WEAI) in BIHS dataset. However, the study does not focus specifically on WEAI. WEAI excludes key domains of empowerment, such as freedom of mobility and violence, which are deemed very important in the context of Bangladesh. The significance of context for added dimensions has been detailed out more in section 2 and 3.2. After reviewing the relevant literature, I have excluded some dimensions of WEAI and incorporated two dimensions in women empowerment index. Thus, this study measures empowerment with five dimensions: (i) domestic violence, (ii) mobility restrictions, (iii) influence on decision-making regarding production activities, (iv) participation in income, and (v) leadership. The study considers the relationship between these dimensions and migration which includes overall, internal and international migration separately.

The empirical approach recognises that migration and empowerment are likely endogenous. Unobserved household conditions could simultaneously determine both empowerment and the decision to migrate; while migration could result from existing levels of empowerment. As a result, I adopt an instrumental variable approach using geographical distance and migration network as instruments for migration. Findings suggest that women, who are left behind, are having mobility restrictions. Additionally, they become more proactive to take decision for production activities. The results infer that migration leads to improvements in bargaining power of left-behind women. This study further tests this proposition by looking at changes in empowerment due to other shocks to household size, including death, marriage, divorce and other separations and show consistent results.

The next section of this paper presents a review of the relevant literature. The theoretical understanding underlying this study is then outlined, followed by a discussion of the data and descriptive evidence. After this, the paper presents the model and methodology. Then, it discusses the results and robustness tests. The final section concludes this chapter.

\section{LITERATURE REVIEW}

This study fits into a growing strand of the migration literature that looks at the relationship between migration and empowerment of left-behind women. It is difficult to establish a direct relationship between women's empowerment and out-migration because empowerment tends to be unobserved and difficult to define (Sinha, Jha \& Negi, 2012). Conceptually, migration of household members could prompt those leftbehind to develop their skills, confidence and bargaining power (Chen, 2006). Thus, the consensus is that migration improves empowerment. 
Migration mediates household structure significantly with different consequences for gender roles and results in different types of household composition. It is found that women in nuclear families (family unit made up usually of the parents and children) tend to have more responsibilities and greater autonomy than women in extended families (Desai \& Banerji, 2008). Migration of a member, especially primary male member typically entails expansion of wives' responsibilities which are not traditionally undertaken by women; for instance, women often need to join employment in informal sector to cope with the low level of income or remittances (Hondagneu-Sotelo, 1992) or to meet per capita expenditure on food per day in extended family as in larger household limited income may affect dietary intake and nutritional status of household member (Baer, 1993; Chaudhury, 1984). Moreover, women living with extended family, while their husband is away, are subject to strict supervision and regulation and must cope without help from their husbands mediating between them and the extended households (Desai \& Banerji, 2008). Thus, absence of a member in household in some instances increases work burden of women, but on the other side, it provides conditions for fostering women's autonomy, self-esteem and role expansion.

While remaining behind, women are the most important pillar for supporting the family migratory strategy through their participation to the labour market, provision of domestic work and as a caretaker for children and male migrant's parents (Vullnetari, 2012). The absence of a migrant member may lead to a shift in decision making power, possibly affecting individual outcomes. Chen (2013) proposes a noncooperative model of household decision-making finding that when the father migrates without his family, children spend more time in household production, while mothers spend less time in both household production and income-generating activities.

Greater household decision-making power among women generally fosters improvement in child health and nutrition (Cunningham et al., 2014). A study finds that when the father migrates abroad leaving his family back home, the control of family shifts to the mother, subsequently more resources are allocated to children especially for female children (Mangiavacchi et al., 2018). Similar result has been found by Hadi (2001) who shows that male migration has significant positive effect on women's decision-making capacity and educational attainment of female children in rural Bangladesh. This may happen due to shifting bargaining power to women who get full autonomy of decision making to allocate more resources to their children.

From the existing literature, it can be inferred that migration affects different aspects of women's autonomy which are some of the pathways of achieving empowerment. However, there is no particular measure of empowerment as it varies from different culture and contexts. Malhotra (2003) argues that one of the constraints of measuring women's empowerment is its context-specific nature. Women in Guatemala define empowerment as greater equality, while rural women in Bangladesh define empowerment as more financial independence (Becker, 2012). Due to different perceptions across nations, it is difficult to set a precise definition of empowerment. Therefore, empowerment is a multidimensional concept which varies in different contexts and cannot be reduced to some single and universally agreed set of priorities (Kabeer, 1999).

In the households of South Asian countries, the wife manages to run the household, but does not control the allocation of resources. It is noted that there is a distinction between management and control (Pahl, 1995). Since this study uses data from Bangladesh, it is presumed that households in Bangladesh exist in patriarchal society where households are mostly headed by the man. In addition, especially in the social context of Bangladesh, women's preference over resources is characterized by male guardianship and control over women's life choices (Karim et al., 2018). Here, household management (resource allocation) is considered as the nexus of women's struggle for autonomy. Thus, based on the context of this study, it is necessary to capture elements for women's empowerment which can draw more holistic overviews of the women in Bangladesh.

Although a sizeable portion of literature presents multidimensional approach to measure women's empowerment (i.e. WEAI by Alkire et al., 2013), this study has distinctly chosen dimensions and indicators for empowerment of left-behind women from different aspects which are relevant in the context of Bangladesh. In addition, in the traditional collective model of households, women's bargaining power consists of variables that are exogenous to household (Lancaster et al., 2006); however, the power of a 
woman influencing household decisions can be affected by changes in the household's choice vector (Basu, 2006). Therefore, one of the contributions of this paper is that it allows for the endogenous determination of bargaining power of left-behind women over constraints within household and argues that multidimensional measures are better suited to treat factors that are difficult to measure where multiple components can interact with each other.

\section{EMPIRICAL STRATEGY}

\section{Data}

This study uses panel data at household level from the Bangladesh Integrated Household Survey (BIHS) published by International Food Policy Research Institute (Ahmed, 2013; IFPRI, 2016). The first round is conducted in 2011-12 with a follow-up round holds in 2015. The first wave collects data from 6,503 households in 325 villages spread across 64 districts. In Wave II, 6,439 of the households from Wave 1 are reinterviewed. This wave also includes households that have split since the first interview. Wave 1 has 5,349 male and 1,154 female respondents; in Wave 2, the quantities remained almost identical. The sample is statistically representative of rural areas in the seven administrative divisions: Barisal, Chittagong, Dhaka, Khulna, Rajshahi, Rangpur and Sylhet.

Table A1 (Appendix A) summarises the relevant statistics for the dependent, independent, control and IVs used in this study. The primary respondents - male and female - are aged 17 and older, and about 90 percent are married. The major predictor is migration of any member of household. The survey aims to capture migratory experiences by interviewing 2,294 migrants. Migration variable is indicating one who has left household for six months or more within the last five years, either within the country or abroad. For the dependent variables, empowerment indicators, study has chosen data from WEAI module which is one of the unique features of the BIHS dataset. In total, 2,367 women respond the WEAI module. Furthermore, the study also uses data from the module containing information on various aspects of women's employment, freedom, lifestyle, and decision-making authority.

\section{Key Dimensions of Women's Empowerment}

In addition to standard modules capturing household and individual-level characteristics, the survey has a special section aiming to measure women empowerment using indicators for the Women's Empowerment in Agriculture Index (WEAI). The WEAI is an aggregate index that assesses the degree to which respondents are empowered in agricultural sector using five domains: (i) Decisions about agricultural production; (ii) Access to decision-making power about productive resources; (iii) Control of using income; (iv) Leadership in the community; and (v) Time allocation (Alkire, et al., 2013). WEAI combines these five domains of empowerment with gender parity index (GPI), which is a measure of empowerment gap between primary male and female in each household.

For this study, all indicators or dimensions of WEAI are not appropriate because WEAI omits categories that are relevant to the Bangladeshi context. After assessing each domain of WEAI, it is found that domain on decision-making power (domain ii), control income (domain iii) and leadership in community (domain iv) can be applied for non-agricultural sector, while indicators of time allocation (domain iv) have too little variation which will produce arbitrariness and biasness in the non-agricultural sector (Malapit, et al., 2015).

In addition, WEAI excludes some key domains of empowerment such as freedom of mobility and violence which are very important in the context of Bangladesh. Domestic violence is an intrinsically important component of empowerment and correlated with household bargaining power (Huis, et al., 2017; Kabeer, 1999; Naved \& Persson, 2005). That is why, I include domestic violence using indicators of physical and emotional violence. I also add a dimension capturing mobility restrictions, which have been identified as one of the important characteristics of women's empowerment (Hossain \& Kabir, 2001). Finally, I combine some of the indicators from domain (i) and domain (ii) in the WEAI to create a women's decision-making influence regarding production activities domain. The next subsection details the various dimensions, their indicators and descriptions. 


\section{Dimensions and Indicators}

This study measures women's empowerment according to five key dimensions: (i) domestic violence, (ii) mobility restrictions, (iii) participation in production activities, (iv) participation in income, and (v) leadership. I identify indicators for each dimension and provide a summary in Table 1.

TABLE 1

INDICATORS OF WOMEN'S EMPOWERMENT

\begin{tabular}{|c|c|}
\hline Indicators & Description $^{\mathrm{a}}$ \\
\hline \multicolumn{2}{|l|}{ Domestic Violence } \\
\hline Experiences physical violence & $\begin{array}{l}\text { Respondent stated that she has been beaten or threatened by her } \\
\text { husband or any family member for divorce or taking another wife. }\end{array}$ \\
\hline Experiences emotional violence & $\begin{array}{l}\text { Respondent stated that she has been verbally abused by her } \\
\text { husband or another family member. }\end{array}$ \\
\hline \multicolumn{2}{|l|}{ Mobility restrictions } \\
\hline $\begin{array}{l}\text { Unable to visit relatives or } \\
\text { friends }\end{array}$ & $\begin{array}{l}\text { Respondent stated that she is not allowed to visit relatives or } \\
\text { friends by herself. }\end{array}$ \\
\hline Unable to go to market & $\begin{array}{l}\text { Respondent stated that she is not allowed to go to market by } \\
\text { herself. }\end{array}$ \\
\hline Unable to receive training & $\begin{array}{l}\text { Respondent stated that she is not allowed to receive training from } \\
\text { non-government organisations by herself. }\end{array}$ \\
\hline \multicolumn{2}{|l|}{ Production activities ${ }^{b}$} \\
\hline $\begin{array}{l}\text { Does not participate in } \\
\text { production }\end{array}$ & $\begin{array}{l}\text { Respondent stated that she does not participate in production } \\
\text { activities. }\end{array}$ \\
\hline $\begin{array}{l}\text { Does not participate in decision- } \\
\text { making regarding production }\end{array}$ & $\begin{array}{l}\text { Respondent stated that she does not participate in decision-making } \\
\text { regarding production. }\end{array}$ \\
\hline \multicolumn{2}{|l|}{ Income } \\
\hline Does not have money to spend & $\begin{array}{l}\text { Respondent stated that she has no money that she can spend as she } \\
\text { chooses. }\end{array}$ \\
\hline Does not earn money & $\begin{array}{l}\text { Respondent stated that she does not earn any money, alone or } \\
\text { jointly. }\end{array}$ \\
\hline \multicolumn{2}{|l|}{ Leadership } \\
\hline $\begin{array}{l}\text { Does not feel comfortable } \\
\text { speaking in public }\end{array}$ & $\begin{array}{l}\text { Respondent stated that she does not feel comfortable speaking in } \\
\text { public regarding any of the following topics: infrastructure (e.g., } \\
\text { small wells, roads, water supplies) in her community, ensuring } \\
\text { proper wages for public work, protesting misbehaviour by } \\
\text { authorities or intervening in family disputes. }\end{array}$ \\
\hline
\end{tabular}

Note. Indicators were generated using data from 'Bangladesh Integrated Household Survey (BIHS) 2015', by the International Food Policy Research Institute, 2016.

${ }^{a}$ When these criteria were met; the dummy variable was taken as 1. bProduction activities include farming crops, raising livestock, non-farm economic activities, waged or salaried employment and fishing or fish culture.

Now, below I highlight additional key description facts how women's constraints are more activated within households.

Domestic Violence. In Bangladesh, domestic violence by intimate partner is highly prevalent, with 1 in 2 women aged 15 or over who have ever been married reporting that they have endured physical violence during their lives and 1 in 4 reporting such violence in the past 12 months (BBS, 2016). In Bangladesh, men's controlling behavior is central to normative masculinity that it is internalized, and its instrumental success enhances men's life satisfaction (Yount et al., 2016). In the sample used in this study, 14\% of women face physical violence by husband, another family member, or household resident and $0.21 \%$ are victim of emotional violence such as threatened by husband with divorce, taking another wife or verbally 
abused by any of the family member. Although the percentage of emotional violence is lower than physical violence, the statistics infers that women are often victim of such behaviour by their family member. This statistics signals the co-occurrence of multiple expressions of control and dominance with physical and psychological perpetration in patriarchal settings.

Mobility Restrictions. Restriction for movement is another key constraint to women's bargaining power as the ability to move around outside of the home opens up various empowering opportunities for women (Hossain \& Kabir, 2001). Socio-religious customs of purdah and norms especially in rural Bangladesh restrict women's movement which further limits their resources, agency and opportunity (Kabeer, 2011). The evidence found in the summary statistics (in table A1) of the sample report that $79 \%$ women are not allowed to visit her relatives or friends, $78 \%$ are restricted to go to market and $71 \%$ are restricted to participate any training program from any NGO. These results note that rural women in Bangladesh are more likely to be confined into their houses because of broader restrictions on their mobility by their husband or other family members.

Production Activities. In the system of patriarchal in Bangladesh, the division of labour becomes highly gendered, with women working inside the house and men working outside the house (Alam, 2007; Baden et al., 1994; Chowdhury, 2009). As a result, women tend to be "invisible" in the agricultural sector in Bangladesh, owing to the assumption that women are not involved in agricultural production because of cultural norms that value female seclusion and undervalue female labour (Kabeer, 1994; Rahman, 2000). It is also reflected in the sample where $78 \%$ women do no participate in production activities and $80 \%$ women does not participate in decision-making process regarding production activities. This domain reflects the relative autonomy of women in production if she participates and has at least some input in decision regarding production activities. This large proportion indicates how women have inadequate achievement with respect to this domain.

Income and Spending. Control over income is another constraint for women which reflects whether a woman is able to benefit from her efforts. This is especially important because in many cases, even where women produce crops or livestock, they are marketed by men who then keep most of the income (Alkire et al., 2013). The general perception in Bangladesh is that women's power increases when they earn more money, however, in reality, women's income in Bangladesh is mostly controlled by husbands by adopting number of strategies to accumulate their own wealth (Chowdhury, 2010). It is also reflected in the sample where almost 60 percent women are found having no freedom of spending money and Nevertheless, the present condition is improving since in the sample, almost 90 percent women are found to be non-earning member.

Leadership. This domain aims to capture the constraints of women's potential for leadership and influence in her community, which Narayan (2002) cites as key elements of empowerment. Leadership domain presents an indication of women's empowerment on exerting voice and engaging in collective action. Because of social and cultural norms, women especially from rural part of Bangladesh do not want to join activities outside the household as family members do not approve (Alkire et al., 2013). It is also reflected in the sample where 17 percent women do not feel comfortable speaking up in public consists of responses to questions about the person's ease in speaking up in public to help decide on infrastructure (like small wells, roads) to be built, to ensure proper payment of wages for public work or other similar programs, and to protest the misbehaviour of authorities or elected officials.

\section{Construction of Empowerment Index}

Therefore, the study uses all indicators under each dimension mentioned above to construct women empowerment index, based on Alkire-Foster Method (AFM) (Alkire et al., 2013). In fact, the index measures the intensity of disempowerment, conversely to empowerment, since the indicator is equal to 1 when the criteria is not fulfilled and 0 otherwise. The level of satisfaction associated with each indicator of the indicator is known as threshold or cut-off point.

In line with the AFM, the threshold of the index determines the extent to which individuals are empowered. For instance, if the threshold is 20 percent and strict deprivation cut-off, then the person is empowered. In other words, women are empowered if their deprivation is 20 percent or less; they are 
disempowered if their deprivation is greater than 20 percent. While AFM methodology is specially an extended work of Alkire and Santos (2010) to develop a Multidimensional Poverty Index (MPI), the AFM is flexible with respect to the dimensions, cut-offs, weights, and indicators used. Thus, I test different cutoffs to determine appropriate threshold for this study.

I use cut-off points of two dimensions in the preferred specification and of one and three dimensions in robustness exercises. A measure of wellbeing using a cut-off of two or more dimensions is most widely used in the literature (de Milliano, Plavgo, 2017). Table 2 shows headcounts of the first three cut-offs of empowerment index using AFM (deprived in at least one, two, or three dimensions). Approximately 98 percent of female in the dataset are deprived in one or more dimensions, while 82 percent are deprived in two or more. More than one-fifth (3\%) of women suffer deprivation in at least three dimensions. The table also reveals a standard error and $95 \%$ confidence interval of the coefficient which gives the results statistical significance.

TABLE 2

FEMALE'S HEADCOUNT RATIO IN EMPOWERMENT INDEX AT DIFFERENT THRESHOLDS

\begin{tabular}{lllll}
\hline Thresholds & Coefficients & SE & \multicolumn{2}{c}{ 95\% Confidence Interval } \\
\hline Deprived in at least 1 dimension & 0.984 & 0.001 & 0.083 & 0.085 \\
Deprived in at least 2 dimensions & 0.822 & 0.002 & 0.19 & 0.25 \\
Deprived in at least 3 dimensions & 0.025 & 0.001 & 0.024 & 0.026 \\
$N$ & 54951 & & & \\
\hline
\end{tabular}

However, Alkire-Foster method (AFM) has been faced a series of criticism; for instance, the method uses 'dual' cut-off method and weighting scheme within chosen dimensions that can result into multiply the deprivation of individuals (Duclos \& Tiberti, 2016). This study further uses three other techniques to check whether the effect or results have any drastic change or dissimilarities across different measures. To check the robustness of the empowerment measurement, the other three measures are: principal component analysis (PCA), multiple correspondence analysis (MCA) and factor analysis (FA). All three measures can be directly applied to the categorical variables as the indicators of the index include binary numbers.

Principal components analysis (PCA) is widely used in empirical applications as an aggregating technique (Krishnakumar \& Nagar, 2008), that uses the correlation between different indicators to perform an orthogonal transformation, thereby creating a set of uncorrelated latent variables. It is important to be aware of determining each of components that orthogonal to each other, which might not be the case in actuality for each of the latent concepts that are sought to be measured (ibid). Compared to PCA, multiple correspondence analysis (MCA) is considered a better technique for binary and categorical as it imposes fewer restrictions within the data structure (Booysen, et al., 2008). In addition, factor analysis (FA) is another popular technique that is used to aggregate variation of indicators. Like PCA, FA is also used as a data reduction method; however, FA is a model-based method that focuses on explaining the common variance across indicators instead of total variance (Alkire et al., 2015).

\section{Treatment Variable and Other Covariates}

Women's empowerment is taken as a major outcome variable in relation to changes in family size through migration of any family member from the household. Migration variable is considered when a member of the household has lived away from the household for six months or more within the last five years, either within the country or abroad. The data are analysed in terms of internal, international and overall migration.

The control variables used in the model are demographic characteristics (e.g., age, age squared, gender, marital status, family size, number of children), socio-economic status (e.g., level of education, occupation, income, wealth index, location of work [rural or urban]), and the size of the assets purchased at the time of 
marriage. The wealth index scores of respondents are determined using principal component analysis, with factor scores assigned to each household. Wealth index is taken to include all durable goods (the relevant durable goods were trunks, buckets, stoves, metal pots, beds, cabinets, tables, hukka, electric fans, electric irons, radios, audio cassettes, wall clocks, televisions, jewellery, sewing machines, bicycles, boats with and without engines, motorcycles, mobile phones, wired phones, dheki, jata, randa, saw, hammer, patkoa, fishing nets, spades, axes, shovels, shabol, daa, asses, solar energy, electric generators and ips) owned by a household that indicates the household's relative economic status, rather than its income. Since the study sought to observe change over time, the year is taken as the time variable.

Empowerment and migration experience could be jointly determined which arises endogeneity problem. The experience of having a migrant member could increase the capabilities of women and lead to empowerment; conversely, the opposite might occur, an empowered woman can motivate or encourage family member to migrate with the confidence that she will take care of the household's responsibilities alone during his absence. To deal with this endogeneity in the model, the study uses two instrumental variables (IV) which are significant determinants of migration. These two IVs are: distance between origin and destination and previous settlement record of migration in the destination over the last 10 years mentioned as migration network. These variables were obtained from the database of migration report, labour statistics and geographical variables (BBS, 2015; ILOSTAT, 2019; CEPII, 2019).

\section{Empirical Model}

To assess the impact of migration on the women's empowerment, the study needs to deal with the causality of migration. This study uses the following model to assess the effect of absence of a member through migration on women's empowerment:

$E_{i, j, t}=\beta_{0}+\beta_{1} M_{i, j, t}+\beta_{2} X_{i, j, t}+\Phi_{i, t}+\varepsilon_{i, j, t}$

where the subscript $i$ indicates individual within a household $(j)$ in a given year $(t) . E_{i, j, t}$ is a dummy variable indicating the women's empowerment index , $M_{i, j, t}$ is also a dummy variable indicating household where husband is a migrant, $X_{i, j, t}$ is a vector of control variables, including individual like women's age, marital status, level of education, occupation, location of work, and household characteristics include number of children, income, wealth index, location of work, and the size of the assets purchased since marriage, $\Phi_{i, t}$ is the woman fixed effect; and $\varepsilon$ is the idiosyncratic error term.

The above model is estimated using individual fixed effect and robust standard errors are stratified and clustered at the district level (with 64 districts in total). The fixed effect model allows the estimation to control for time-invariant omitted variable bias at individual level. In addition, strata usually reduce the standard error and clusters increase variance; therefore, adjusting the standard error (Abadie et al., 2017). As mentioned before, in the estimation, empowerment is, in fact, a measure of disempowerment. Thus, $E$ is equal to 1 if a woman is disempowered. The empirical test of the model starts with the measures of empowerment on their own and then use indices. Measuring empowerment in each component of the index is important because empowerment has been conceptualized with different indicators and it varies in the extent to which they conceptualize or discuss how to identify it (Malhotra et al., 2002).

Empowerment index is measured in all four methods (AFM, PCA, MCA, FA) and regressed as dependent variable in the model. The regression model is also run for each indicator of five dimensions as dependent variable. In the first stage of estimation, a standard linear probability model (LPM) is used to project the relationship between the regressors and the dependent variable. Because the sample deals with binary dependent variables, endogeneity and a short-panel fixed effect, it is possible that the LPM would be a good fit for the estimation (Dong \& Lewbel, 2015). However, it is difficult to estimate the causal effects of the explanatory variable on the dependent variable using a standard linear approach because both approaches would give an incorrect approximation for such a model. Thus, it is necessary to fix the endogeneity problem. This study employs two-stage least squares form of instrumental variable (IV) regression. IV regression is used because some elements of treatment indicators in LPM are endogenous 
which are correlated with error term. I choose to use multiple instruments as the system of equations is appeared to be overdetermined (i.e., the numbers of equations are greater than the numbers of unknowns) (Angrist \& Pischke, 2009).

Therefore, IV regression is employed as a potential solution to estimate the causal effect of treatments on the outcome variable through the addition of an exogenous variable (an 'instrument'). To be valid, an instrument must satisfy two properties: it must be substantially correlated with the endogenous regressor and uncorrelated with the error term (Mullers et al., 2014). An IV estimator is consistent as long as it satisfies these criteria; despite this, it cannot be considered an unbiased estimator because it might have a substantial bias in small sample sizes (Wooldridge, 2008).

Two instrumental variables are used: distance between origin and destination, and previous settlement record of migration in the destination over the last 10 years. The first - the geographical variable of the distance between the migrant's origin and destination - could be a proxy of migration cost. This variable has been used as an instrument by many researchers because geographical variables can easily be taken as exogenous variables (Orefice, 2010). Distance has been a primary and longstanding focus for analysis of a wide range of spatial interaction phenomena, including residential relocation through migration (Stillwell $\&$ Thomas, 2016). It is a well-known axiom that migration declined with distance, but the propensities to move over distance are likely to vary according to the various demographic, economic and social characteristics of individual migrants as well as their households. For instance, Niedomysl (2011) used a large-scale survey in Sweden to explore how migration motives change over migration distance and these results confirm a well-known generalization dichotomy. The result finds that the purpose of migrants who move shorter distances is housing reason and people who migrate for the purpose of employment move longer distance.

The second instrument used in this study is the previous settlement record of migration in the destination over the last 10 years (called the 'migration network' variable). This is inspired by Card's (2001) shift-share instrument. Other studies have used similar instruments, such as network effects or the record of prior settlement in the destination country. Card's shift-share instrument defines previous migration patterns from the country of origin to the host country. The second IV used in this study is constructed according to Card's method for estimating the shift-share instrument. A simplified version of the second IV can be written as follows:

$$
Z_{2}=\sum \frac{P_{o j t^{0}}}{P_{o j t^{0}}} \frac{\Delta P_{o j t}}{L_{j t-1}}
$$

Here, $\frac{P_{o j t^{0}}}{P_{o j t^{0}}}$ is the share of the population who are out-migrants from the origin country $(o)$ in the destination $(j)$ during the reference year $\left(t^{0}\right)$, which is 2011. $\Delta P_{o j t}$ is the number of in-migrants in the destination in 2011 and $L_{j t-1}$ is the total local population in 2001.

To estimate the probability estimation for a discrete choice outcome i.e. migrate or not, the instruments are added, and a reduced form of equation generated:

$M_{i, j, t}=\pi_{0}+\pi_{1} Z_{i, j, t}+\pi_{2} X_{i, j, t}+\mu_{\mathrm{j}, \mathrm{t}}+u_{i, j, t}$

where $Z_{i, j, t}$ is a vector of instrumental variables, $\mu_{\mathrm{j}, \mathrm{t}}$ is individual fixed effect and $u_{i, j, t}$ is error term.

The set of instruments satisfies specific assumptions. First, these variables are uncorrelated with error $\varepsilon$, meaning that they are not directly correlated with the empowerment variable. It is noted that the empowerment measure is estimated for women only and the migration measure estimated for any family member who migrates. Furthermore, the $F$-statistics in the first stage of the IV estimation are larger than 10 (see Table B4) and the significance of Sargan's test is appeared with larger values. These two features indicate the validity of the instruments. 


\section{FINDINGS}

\section{Exploring Different Indices}

Since this study calculates women's empowerment index in four econometric techniques, this section analyses how migration affects overall women's empowerment index in different measures. Table 3 shows the associations between migration and empowerment index identified using each measure and according to the two different types of estimations: LPM and IV. Here, the dependent variable is women empowerment index measured in four different measures: AFM, PCA, MCA and FA.

While four of them are the most popularly employed techniques for index creation, there are some inherent differences among these methods. Three of the techniques i.e. PCA, MCA and FA eventually provide similar results because each method seems to have drawn nearly the same weights for the indicators. The fundamental difference is that PCA assumes the distances between the categorical values are the same, whereas MCA imposes fewer constraints on the data and determines larger variation given a binary or categorical dataset (Pasha, 2017). Another technique, FA as such resembles PCA to a large extent. Unlike PCA, FA focuses on explaining the common variance across indicators instead of total variance. Compared to three other measures, AFM signifies redundancy or overlap which ultimately indicates a person who is deprived in the indicator with lower headcount is also deprived in another indicator. For example, in table 3 , AFM result is shown for deprivation in at least two dimensions which refer that 40 percent of the women who are deprived in the indicator having the lower marginal headcount ratio are also deprived in the other indicator.

In this section, the results related to the AFM technique are examined first and then it moves on to the other techniques. The regression result for women empowerment index measured by AFM shows statistically significant for migration, which is the major treatment variable in this study, whereas coefficients for migration come as insignificant when women empowerment index is measured in other techniques. The results suggest that an equal standardized weight across different dimensions may not be the most ideal construct to deliver the best results when determining the level of multidimensional deprivation with a given dataset. 


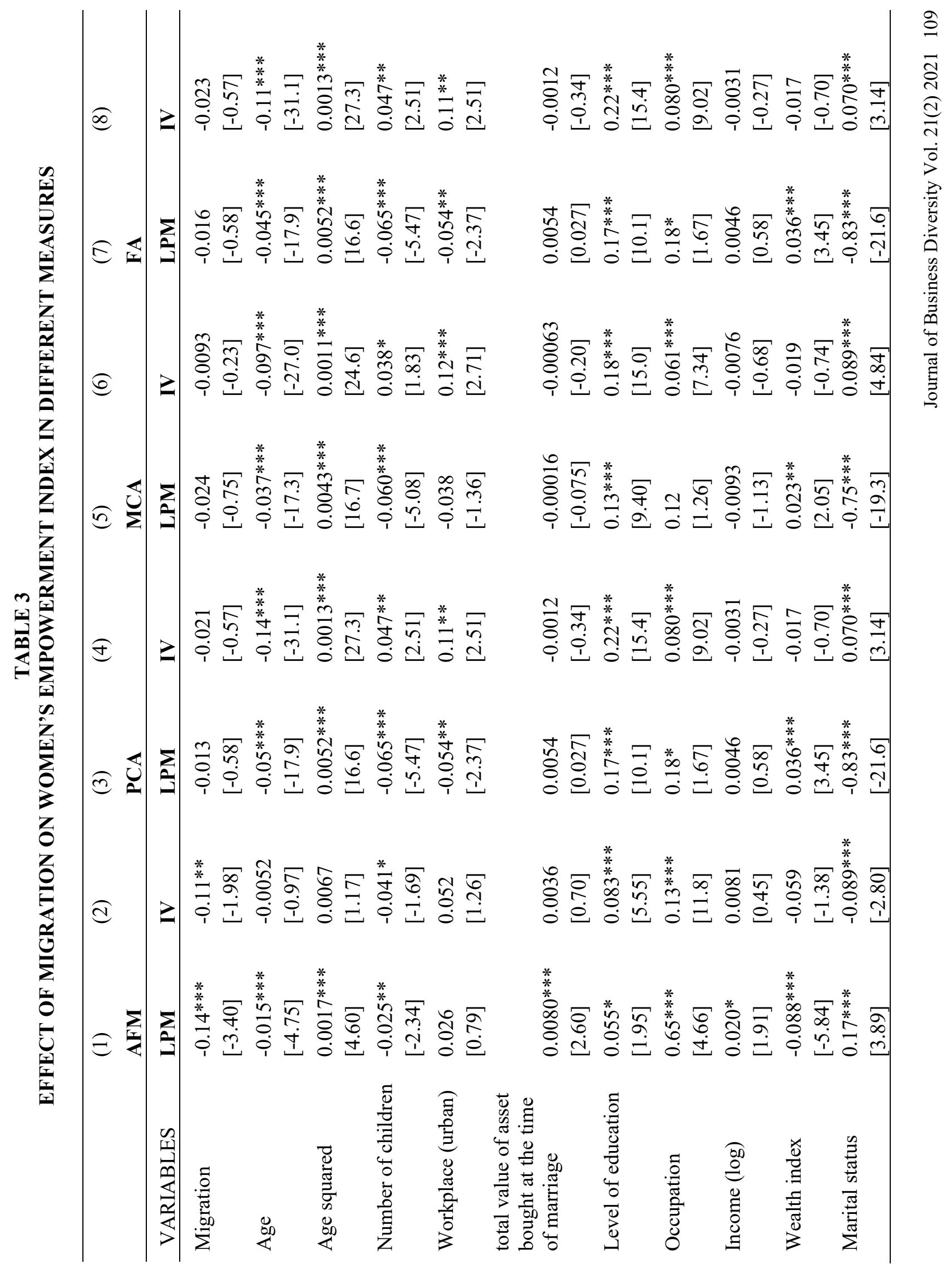




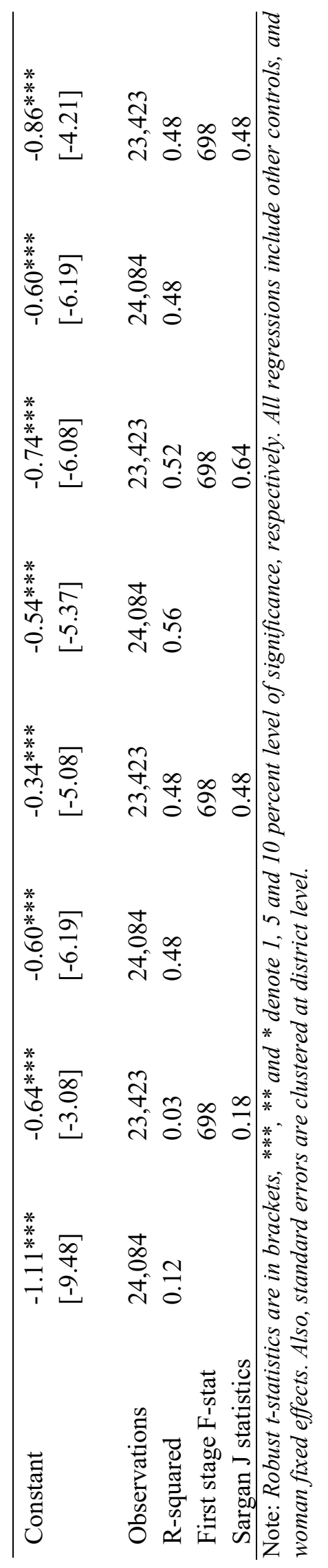


The LPM results show a negative and significant association with the women's empowerment index measured in Alkire-Foster Method (AFM). It is noted that in Table 3, the deprivation threshold is determined at $40 \%$ which means disempowered in at least two dimensions or more. To check the robustness of the result, the study also performs estimation considering different cut-offs points such as deprivation in at least one (20\%) and three (60\%) dimensions (see the table B12-B13). Since the empowerment index measures deprivation, negative association indicates that migration reduces disempowerment, thus migration improves women's empowerment. For internal and international migration, it is also found as significant in AFM measures. The other estimation by IV regression, trend of association and significance has been found similar as LPM results. However, a significant difference is found for international migration. It says that having international migrants in household decreases women's disempowerment by $14 \%$ which is higher than that of overall and internal migration, even higher than the results estimated by LPM. In addition, except for the results of empowerment index measured in AFM, coefficients do not come statistically significant for other three measures.

To summarise, the different econometric measures support the finding that the status of women changes with the shock of migration. Although there are some variations in the results, these measures emphasise the effect of the main predictor-migration. Notably, the coefficients of the IV estimation are greater than those of the LPM. This reinforces the efficacy of the model because it means that the instruments strongly explain the component of migration. Thus, the overall pattern of results is consistent with the hypothesis that migration changes constraints on women's wellbeing.

\section{Regression Results Using Separate Empowerment Indicators}

This section presents and discusses the regression results of each of the indicators under five dimensions of empowerment index. In table 4, panel A to E present the LPM and IV results of estimation of equation (1). The entire results with all control variables are presented in table B2-B9 in appendix. The dependent variable in table 4 is indicators of women's empowerment under five dimensions, which are defined with a dummy variable equal to 1 if woman is deprived in that indicator. Panel A focuses on domestic violence, panel B focuses on mobility restrictions, panel C presents participation in production activities, panel D presents participation in income and panel E represents the dimension of leadership. Each indicator of dimensions is regressed with the main variables of interest are the overall migration, internal and international migration, separately which are presented in table 4 . Control variables include age, age squared, marital status, number of children, level of education, occupation, income, wealth index, location of work, and the size of asset bought at the time of marriage. A negative coefficient indicates that husband's migration is conditionally associated with a decrease in women deprivation in particular indicator.

Panel A for LPM estimation in Table 4 reveals that domestic physical and emotional violence are mostly negatively associated with migration. A significant association is found for the effect of international migration on physical violence which shows that international migration of a household member significantly decreases the probability of physical violence on woman of the household by 4 percent. In addition, migration significantly decreases emotional violence on woman although the magnitude is small. Similarly, panel B shows that women from migrant households do not enjoy more freedom to visit friends, relatives, travel to market and receive training from non-governmental organisations. Panel $\mathrm{C}$ also shows that the coefficients attached to production activities are found to be statistically significant for all types of migration of a member. 
TABLE 4

EFFECT OF MIGRATION ON INDICATORS OF WOMEN'S EMPOWERMENT

\begin{tabular}{|c|c|c|c|c|c|c|}
\hline \multirow[b]{3}{*}{ Dependent variables } & (1) & $(2)$ & (3) & (4) & \multicolumn{2}{|c|}{$\begin{array}{l}(5) \\
\text { International } \\
\text { migration }\end{array}$} \\
\hline & \multicolumn{2}{|c|}{ Overall migration } & \multicolumn{2}{|c|}{ Internal migration } & \multicolumn{2}{|c|}{$\begin{array}{l}\text { International } \\
\text { migration }\end{array}$} \\
\hline & LPM & IV & LPM & IV & LPM & IV \\
\hline \multicolumn{7}{|c|}{ Panel A: Domestic violence } \\
\hline \multirow{2}{*}{ Physical Violence } & $-0.027 * * *$ & 0.0099 & $-0.021 *$ & 0.014 & $-0.040 * * *$ & 0.032 \\
\hline & {$[-2.82]$} & {$[0.71]$} & {$[-1.89]$} & {$[0.74]$} & {$[-3.61]$} & {$[0.63]$} \\
\hline Hansen p-value & & 0.58 & & 0.60 & & 0.52 \\
\hline First stage F-stat & & 684 & & 356 & & 32 \\
\hline \multirow[t]{2}{*}{ Emotional Violence } & $-0.0013^{*}$ & -0.00052 & -0.0011 & -0.00070 & -0.0015 & -0.0019 \\
\hline & {$[-1.71]$} & {$[-0.46]$} & {$[-1.38]$} & {$[-0.45]$} & {$[-1.29]$} & {$[-0.47]$} \\
\hline Hansen p-value & & 0.85 & & 0.83 & & 0.91 \\
\hline First stage F-stat & & 684 & & 356 & & 32 \\
\hline \multicolumn{7}{|c|}{ Panel B: Mobility restrictions } \\
\hline \multirow[t]{2}{*}{ Unable to go to market } & -0.010 & -0.024 & -0.010 & -0.032 & -0.0048 & -0.087 \\
\hline & {$[-0.85]$} & {$[-1.48]$} & {$[-0.74]$} & {$[-1.45]$} & {$[-0.30]$} & {$[-1.49]$} \\
\hline Hansen p-value & & 0.65 & & 0.61 & & 0.76 \\
\hline First stage F-stat & & 684 & & 356 & & 32 \\
\hline \multicolumn{7}{|l|}{ Unable to visit relatives or } \\
\hline \multirow[t]{2}{*}{ friends } & 0.0011 & -0.0095 & 0.000012 & -0.011 & 0.0054 & -0.043 \\
\hline & {$[0.10]$} & {$[-0.66]$} & {$[0.00098]$} & {$[-0.59]$} & {$[0.39]$} & {$[-0.83]$} \\
\hline Hansen p-value & & 0.14 & & 0.14 & & 0.15 \\
\hline First stage F-stat & & 684 & & 356 & & 32 \\
\hline \multirow[t]{2}{*}{ Unable to receive training } & -0.013 & $-0.038^{*}$ & -0.011 & $-0.050 *$ & -0.020 & -0.14 \\
\hline & {$[-0.86]$} & {$[-1.71]$} & {$[-0.59]$} & {$[-1.72]$} & {$[-1.41]$} & {$[-1.62]$} \\
\hline Hansen p-value & & 0.22 & & 0.20 & & 0.28 \\
\hline First stage F-stat & & 684 & & 356 & & 32 \\
\hline \multicolumn{7}{|c|}{ Panel C: Participation in production activities } \\
\hline \multicolumn{7}{|c|}{ Does not participate in } \\
\hline production & $-0.11 * * *$ & $-0.15 * * *$ & $-0.099 * * *$ & $-0.20 * * *$ & $-0.13 * * *$ & $-0.53 * * *$ \\
\hline & {$[-4.41]$} & {$[-4.77]$} & {$[-4.09]$} & {$[-4.91]$} & {$[-3.38]$} & {$[-3.91]$} \\
\hline Hansen p-value & & 0.15 & & 0.14 & & 0.58 \\
\hline First stage F-stat & & 684 & & 356 & & 32 \\
\hline $\begin{array}{l}\text { Does not participate in } \\
\text { decision-making regarding }\end{array}$ & & & & & & \\
\hline production & $-0.11 * * *$ & $-0.14 * * *$ & $-0.10 * * *$ & $-0.19 * * *$ & $-0.13 * * *$ & $-0.50 * * *$ \\
\hline & {$[-4.65]$} & {$[-4.88]$} & {$[-4.45]$} & {$[-5.01]$} & {$[-3.38]$} & {$[-4.01]$} \\
\hline Hansen p-value & & 0.16 & & 0.19 & & 0.60 \\
\hline First stage F-stat & & 684 & & 356 & & 32 \\
\hline
\end{tabular}




\section{Panel D: Participation in income}

$\begin{array}{lllllll}\begin{array}{l}\text { Does not have money to } \\ \text { spend }\end{array} & 0.0050 & 0.016^{*} & 0.0052 & 0.022^{* *} & 0.0012 & 0.057^{*} \\ & {[0.82]} & {[1.95]} & {[0.69]} & {[1.97]} & {[0.18]} & {[1.79]} \\ \text { Hansen p-value } & & 0.88 & & 0.82 & & 0.96 \\ \quad \text { First stage F-stat } & & 684 & & 356 & & 32 \\ \text { Does not earn money } & 0.023^{* *} & 0.023^{* *} & 0.0058 & 0.031^{* *} & 0.057^{* * *} & 0.084^{* *} \\ & {[2.57]} & {[2.21]} & {[0.72]} & {[2.18]} & {[3.43]} & {[2.20]} \\ \text { Hansen p-value } & & 0.43 & & 0.38 & & 0.61 \\ \text { First stage F-stat } & & 684 & & 356 & & 32\end{array}$

\section{Panel E: Leadership}

Does not feel comfortable

\begin{tabular}{lllllll} 
speaking in public & $0.086^{* * *}$ & $0.10^{* * *}$ & $0.077^{* * *}$ & $0.14 * * *$ & $0.100^{* * *}$ & $0.37 * * *$ \\
& {$[5.23]$} & {$[4.99]$} & {$[4.79]$} & {$[4.93]$} & {$[3.87]$} & {$[4.42]$} \\
Hansen p-value & & 0.42 & & 0.29 & & 0.92 \\
First stage F-stat & & 684 & & 356 & 32 \\
Observations & 24,084 & 23,423 & 24,084 & 23,423 & 24,084 & 23,423 \\
\hline Note: Robust t-statistics are in brackets, ***, ** and ${ }^{*}$ denote 1, 5 and 10 percent level of significance, respectively. \\
All regressions include other controls, and woman fixed effects. Also, standard errors are clustered at district level.
\end{tabular}

An interesting outcome is found in relation to participation in income in panel $\mathrm{D}$. The results show that if a member from household migrates overseas, there is no effect on women having opportunity to spend money. However, for overall and international migration, the association is increasing and significant which says that women from migrant or international migrant households are not engaged with earning money. The result of two indicators of income dimension concludes that despite having no option of earning money for women from international migrant households, they have no freedom to spend money independently. Therefore, women in migrant households incur deprivation in income dimension. Similarly, panel E shows all positive and significant association with migration which indicates that women from households with migrant member do not feel comfortable speaking in public regarding any topic of infrastructure in community, wages of work and protesting misbehaviour in family disputes.

The study then addresses potential endogeneity between women's empowerment and migration using instrumental variable strategy. The first-stage IV estimation is presented in table B1 in appendix. The positive sign on the migration network indicates that previous settlement at destination areas increases the probability of migration. For the other instrument, distance is also positively and significantly associated with migration which indicates that migrants from Bangladesh move longer distances for employment purposes. In addition, the first-stage results indicate that the multiple instruments used in the model are valid, with a higher F-statistics and Hansen $p$-value for each regression model (see Table 4).

Table 4 also presents the preferred specification, which uses the methodology of two-stage instrumental variable (IV) estimation. Full IV estimation results are found in table B7-B9. The instruments are tested with first-stage $F$-statistics and Sargan-Hansen statistics. The 'rule of thumb' says that if F-statistics in the first stage of IV estimation are larger than 10, it indicates valid instruments (Angrist \& Pischke, 2008) and the null hypothesis for the Sargan-Hansen says the larger the $p$-value, the more valid the instrument. Thus, the result of IV estimation is interpreted as causal if the coefficient estimates attached to a variable is found to be statistically significant and if the regression passes Sargan-Hansen statistics and F-statistics minimum requirement. As with the previous table, the results are divided into five panels covering the effect of migration, including internal and international, on five dimensions of women's empowerment. The table shows the results of the coefficients estimates of the variables of interest within each in panel. 
Overall, IV results in table 4 show that women from migrant households have less deprivation in the dimension of decision-making, income and leadership. In panel A, the results of IV estimation say that there is no effect of migration on domestic violence. Although the sign of coefficients associated with emotional violence support the LPM result, the results are not statistically significant. In panel B, significant result has been found in the third indicator of mobility restrictions. It says that women left-behind have more freedom to receive training from NGO. In such case, internal migration decreases the probability of restrictions by 5 percent which is higher than that of overall migration.

Another significant result is found in panel $\mathrm{C}$ mentioned participating in production activities. The result shows that after instrumenting migration, it does not have any effect on women's participation in production. However, the result is significant for participating in decision-making regarding production activities. It seems that although women from migrant households have no participation in production activities, the absence of the member results in women having greater decision-making authority over production processes. In panel D, IV estimate resembles the results of LPM for both earning and spending indication which says that left-behind women have less freedom to earn and spend money. The coefficients from IV estimation comes as positive for both indicators of income dimension which indicates that women from migrant household are less likely to involve in earning money, as a result, they do not have freedom to spend money by themselves. Thus, the results in panel D contradicts the concept of greater financial autonomy of the women left-behind supported by both Gulati (1992) and Khaled (1995) who report control over household expenditure for wives of migrated husbands in India and Jordan, respectively. Finally, for the last panel on leadership, the directions of association support the LPM result in panel E and the results are statistically significant which suggests that left-behind women are less likely to participate in community activities such as involvement in public speaking.

In sum, the findings in Table 4 are indicative that women's constraints and migration are strongly correlated. Overall, the results show that the absence of a member through migration decreases deprivation in the constraints of women's empowerment for left behind. The decreased restrictions for receiving training from NGO can be interpreted as women from migrant households being bolder to attend outside. This might happen when there are fewer responsibilities to attend at home in the absence of migrant member and women perhaps mobile by choice. Migration of a member is seen to have the largest effect on leftbehind women's production activities and income compared to the effect on other dimensions. Empowerment in production activities indicates a process of the extent a woman can participate in and make decisions regarding agricultural and non-agricultural production activities. It seems that left-behind women are more active as a primary decision-maker in the household. Additionally, the results from income dimension infers that left-behind women are far from economic empowerment. However, the effect could be differential. Although the study controls for household wealth and income, it could not control for the person who received remittance. This may affect household power dynamics of the women left behind and the in-laws. An investigation of this topic would require using a much larger pool of households with migrant member.

\section{Exploring the Mechanism Through Which Migration Affects Empowerment}

The hypothesis of this study says that migration affects empowerment by changing intrahousehold dynamics; that is, as migration changes household size; it can change relative bargaining powers. Migration is, of course, not the only way through which household size changes. Therefore, this section investigates the role that other shocks to household size, namely death, marriage or divorce, may have on women's empowerment index. This model is estimated using the LPM reported in table B11. These results suggest that when the number of people in the household decreases, the empowerment of the remaining women increases. The same estimations are performed for each indicator of women's empowerment (see table B10), and a similar correlation between changes in household size and women's empowerment has been found. In particular, mobility restrictions decrease when a household member leaves. Therefore, it can be inferred that, when any family member leaves, most responsibilities fall to the women who remain; for that reason, they need to move outside frequently. Not only in mobility restrictions, results show that woman's relative bargaining power has been increased regarding production activities, decision-making, income 
activities and even in public speaking. Simply, the overall results of the alternative model give a similar association of coefficients as the model that uses migration as its major predictor. This proves and validates the hypothesis that when there is a member is absent, woman needs to increase her autonomy to achieve proper household management.

\section{CONCLUSION}

This study explores the effects of migration on women's empowerment. Specifically, it investigates the case of women from rural households in Bangladesh who are left behind when their family member migrates. This study uses a decomposed version of WEAI and measures the women's empowerment using alternative approaches. While constructing the index, it is argued that access to credit and ownership of assets might not determine women's empowerment. Since empowerment varies across contexts and cultures, this research investigates constraints on women relevant to the context of rural Bangladesh.

This study has found that, when a member of household migrates, the women who are left behind become more independent as they make decisions for the household. They also become more mobile, which help them to develop social networks. Moreover, women from households with migrant member face less physical violence within household. Also, they more likely to take part in decision-making process regarding production activities. However, women from migrant household do not have financial independence as they are less likely to participate in earning or spending money by their own.

Extending the analysis, the research argues that migration and women's empowerment are endogenous because empowerment itself could be a push factor. IVs are then used to identify proper causal effects. Based on the existing literature, determinants of migration are used as the IVs. Multiple instrumentations predicted significant differences in the empowerment indices. A robustness check is performed by applying each estimation to a variety of measures - this leads the overall results in the same direction. Although the results are found to be robust, the study could not able to determine why left-behind women are deprived in economic empowerment. Due to limited data, it has yet to be undetermined who receive the remittance which can affect women's power dynamics within the household. Despite this caveat, the findings of this study will be useful for civil society, researchers and policy makers to ensure enhancement in women's empowerment.

\section{REFERENCES}

Abadie, A., Athey, S., Imbens, G.W., \& Wooldridge, J. (2017). When should you adjust standard errors for clustering? (No. w24003). National Bureau of Economic Research.

Ahmed, A. (2013). Bangladesh Integrated Household Survey (BIHS) 2011-2012 [dataset]. Retrieved from https://doi.org/10.7910/DVN/OR6MHT

Alkire, S., \& Santos, M.E. (2010, November). Acute multidimensional poverty: A new index for developing countries. United Nations development programme human development report office background paper.

Alkire, S., Meinzen-Dick, R., Peterman, A., Quisumbing, A., Seymour, G. \& Vaz, A. (2013). The women's empowerment in agriculture index. World Development, 52, 71-91. https://doi.org/10.1016/j.worlddev.2013.06.007

Alkire, S., Foster, J.E., Seth, S., Santos, M.E., Roche, J., \& Ballon, P. (2015). Multidimensional poverty measurement and analysis: Chapter 3-overview of methods for multidimensional poverty assessment.

Angrist, J.D., \& Pischke, J.S. (2008). Mostly harmless econometrics: An empiricist's companion. Princeton university press.

Alam, S. (2007). Islam, culture, and women in a Bangladesh village. Voices of Islam, pp. 35-53.

Alonso, J.A. (2011). International Migration and Development: A review in light of the crisis.

Baden, S., Green, C., Goetz, A.M., \& Guhathakurta, M. (1994). Background report on gender issues in Bangladesh, 26. University of Sussex. IDS. 
Baer, R.D., \& Madrigal, L. (1993). Intrahousehold allocation of resources in larger and smaller Mexican households. Social Science \& Medicine, 36(3), 305-310.

Balk, D. (1994). Individual and community aspects of women's status and fertility in rural Bangladesh. Population Studies, 48(1), 21-45.

Bangladesh Bureau of Statistics. (2015). Population Distribution and Internal Migration in Bangladesh. Population Monograph (6). Retrieved from http://203.112.218.65:8008/WebTestApplication/userfiles/Image/PopMonographs/Volume6_PDIM.pdf

Bangladesh Bureau of Statistics (BBS). (2016). Report on violence against women (VAW) survey 2015. Dhaka: Bangladesh Bureau of Statistics.

Basu, K. (2006). Gender and say: A model of household behaviour with endogenously determined balance of power. The Economic Journal, 116(511), 558-580.

Becker, E. (2012). Themes from Feed the Future Women's Empowerment in Agriculture Index: Report from Qualitative Case Studies in Bangladesh, Guatemala, and Uganda. Unpublished report submitted to the International Food Policy Research Institute, Washington, D.C.: IFPRI.

Booysen, F., van der Berg, S., Burger, R., Maltitz, M.V., \& Rand, G.D. (2008). Using an Asset Index to Assess Trends in Poverty in Seven Sub-Saharan African Countries. World Development, 36(6), $1113-1130$.

Bureau of Manpower, Employment and Training (BMET). (2019). Category-wise overseas employment from 1976 to 2018 [Statistical report]. Retrieved from http://www.old.bmet.gov .bd/BMET/viewStatReport.action?reportnumber $=9$

Card, D. (2001). Immigrant inflows, native outflows, and the local labor market impacts of higher immigration. Journal of Labor Economics, 19(1), 22-64. https://doi.org/10.1086/209979

CEPII Research and Expertise of the World Economy. (2019). GEODIST. Retrieved from http://www.cepii.fr/CEPII/en/bdd modele/presentation.asp?id=6

Chaudhury, R.H. (1984). Determinants of dietary intake and dietary adequacy for pre-school children in Bangladesh. Food and Nutrition Bulletin, 6(4), 1-10.

Chowdhury, F.D. (2009). Theorising patriarchy: The Bangladesh context. Asian Journal of Social Science, 37(4), 599-622.

Chowdhury, F. (2010). Middle Class Married Women's Income in Bangladesh: Who Controls it and How? African and Asian Studies, 9, 1-30. doi:10.1163/156921010X491236

Chen, J.J. (2006). Migration and imperfect monitoring: Implications for intra-household allocation. American Economic Review, 96(2), 227-231. Retrieved from http://www.jstor.org/stable/30034647

Chen, J.J. (2013). Identifying non-cooperative behavior among spouses: Child outcomes in migrantsending households. Journal of Development Economics, 100(1), 1-18. doi:https://doi.org/10.1016/j.jdeveco.2012.06.006

Cunningham, K., Ploubidis, G.B., Menon, P., Ruel, M., Kadiyala, S., Uauy, R., \& Ferguson, E. (2015). Women's empowerment in agriculture and child nutritional status in rural Nepal. Public Health Nutrition, 18(17), 3134-3145.

de Milliano, M., \& Plavgo, I. (2018). Analysing multidimensional child poverty in sub-Saharan Africa: Findings using an international comparative approach. Child Indicators Research, 11(3), 805833.

Desai, S., \& Banerji, M. (2008). Negotiated Identities: Male Migration and Left-Behind Wives in India. Journal of population research (Canberra, A.C.T.), 25(3), 337-355. https://doi.org/10.1007/BF03033894

Dong, Y., \& Lewbel, A. (2015). A simple estimator for binary choice models with endogenous regressors. Econometric Reviews, 34(1-2), 82-105.

Duclos, J-Y. (2011). UNDP's Multidimensional poverty index. Working Paper: Development Indicators. Retrieved from Ferdi. 
Goetz, A.M., \& Gupta, R.S. (1996). Who takes the credit? Gender, power, and control over loan use in rural credit programs in Bangladesh. World Development, 24(1), 45-63. doi:https://doi.org/10.1016/0305-750X(95)00124-U

Gulati, L. (1992). Migration and social change in India. Asian Migrant, 5(4), 124-126.

Hadi, A. (2001). International migration and the change of women's position among the left-behind in rural Bangladesh. International Journal of Population Geography, 7(1), 53-61.

Hassan, H., \& Jebin, L. (2019). Impact of migrants' remittance on the 'left-behind wives': Evidence from rural Bangladesh. Journal of Developing Areas, 54, 127-144. https://doi.org/10.1353/jda.2020.0020

Hondagneu-Sotelo, P. (1992). Overcoming Patriarchal Constraints: The Reconstruction of Gender Relations Among Mexican Immigrant Women and Men. Gender \& Society, 6(3), 393-415. https://doi.org/10.1177/089124392006003004

Hossain, M.K., \& Kabir, M. (2001). Purdah, mobility and women's empowerment and reproductive behaviour in rural Bangladesh. Social Change, 31(3), 84-102. https://doi.org/10.1177/004908570103100307

Huis, M.A., Hansen, N., Otten, S., \& Lensink, R. (2017). A three-dimensional model of women's empowerment: Implications in the field of microfinance and future directions. Frontiers in Psychology, 8, 1678. https://doi.org/10.3389/fpsyg.2017.01678

ILOSTAT. (2019). Statistics on wages. Retrieved from https://ilostat.ilo.org/topics/wages/

International Food Policy Research Institute (IFPRI) (2015). Bangladesh Integrated Household Survey (BIHS) 2015 [dataset]. https://doi.org/10.7910/DVN/BXSYEL

Kabeer, N. (1994). Reversed realities: Gender hierarchies in development thought. Verso.

Kabeer, N. (1999). Resources, agency, achievements: Reflections on the measurement of women's empowerment. Development and Change, 30(3), 435-464. https://doi.org/10.1111/14677660.00125

Kabeer, N. (2001). Conflicts over credit: Re-evaluating the empowerment potential of loans to women in rural Bangladesh. World Development, 29(1), 63-84. https://doi.org/10.1016/S0305$750 \mathrm{X}(00) 00081-4$

Kabeer, N. (2011). Between Affiliation and Autonomy: Navigating Pathways of Women's Empowerment and Gender Justice in Rural Bangladesh. Development and Change, 42(2), 499-528. doi:https://doi.org/10.1111/j.1467-7660.2011.01703.x

Karim, R., Lindberg, L., Wamala, S., \& Emmelin, M. (2018). Men's Perceptions of Women's Participation in Development Initiatives in Rural Bangladesh. American Journal of Men's Health, 12(2), 398-410. doi:10.1177/1557988317735394

Khaled, L. (1995). Migration and women's status: The Jordan case. International Migration (Geneva, Switzerland), 33(2), 235.

Krishnakumar, J., \& Nagar, A.L. (2008). On Exact Statistical Properties of Multidimensional Indices Based on Principal Components, Factor Analysis, MIMIC and Structural Equation Models. Social Indicators Research, 86(3), 481-496.

Lancaster, G., Maitra, P., \& Ray, R. (2006). Endogenous Infra-Household Balance of Power and Its Impact on Expenditure Patterns: Evidence from India. Economica, 73(291), 435-460. Retrieved December 8, 2020, from http://www.jstor.org/stable/3874077

Mahmud, S., Shah, N.M., \& Becker, S. (2012). Measurement of women's empowerment in rural Bangladesh. World Development, 40(3), 610-619.

Malapit, H.J., Kovarik, C., Sproule, K., Meinzen-Dick, R.S., \& Quisumbing, A.R. (2015). Instructional guide on the abbreviated Women's Empowerment in Agriculture Index (A-WEAI). Washington, D.C.: International Food Policy Research Institute (IFPRI). Retrieved from http://ebrary.ifpri.org/cdm/ref/collection/p15738coll2/id/129719

Malhotra, A., Schuler, S.R., \& Boender, C. (2002). Measuring women's empowerment as a variable in international development. In Background paper prepared for the World Bank Workshop on Poverty and Gender: New Perspectives (Vol. 28). 
Malhotra, N. (2003). The Nature of Knowledge and the Entry Mode Decision. Organization Studies, 24(6), 935-959. https://doi.org/10.1177/0170840603024006006

Mangiavacchi, L., Perali, F., \& Piccoli, L. (2018). Intrahousehold distribution in migrant-sending families. Journal of Demographic Economics, 84(1), 107-148.

Momsen, J.H. (2003). Gender, migration and domestic service. Routledge.

Morgan, S.P., \& Niraula, B.B. (1995). Gender inequality and fertility in two Nepali villages. Population and Development Review, 21(3) 541-561.

Mullers, C., Winship, C., \& Morgan, S.L. (2014). In H.B.C. Wolf (Ed.), The SAGE handbook of regression analysis and causal inference. https://doi.org/10.4135/9781446288146

Narayan, D. (2002). Empowerment and Poverty Reduction: A Sourcebook. Washington, DC: World Bank. World Bank. Retrieved from https://openknowledge.worldbank.org/handle/10986/15239 License: CC BY 3.0 IGO.

Naved R.T., \& Persson L.A. (2005). Factors associated with spousal physical violence against women in Bangladesh. Studies in Family Planning, 36, 289-300. https://doi.org/10.1111/j.17284465.2005.00071.x

Niedomysl, T. (2011). How migration motivations change over migration distance: Evidence on variations across socioeconomic and demographic groups. Regional Studies, 45, 843-855.

Orefice, G. (2010). Skilled migration and economic performances: Evidence from OECD countries. Swiss Journal of Economics and Statistics, 146(4), 781-820. https://doi.org/10.1007/bf03399337

Pahl, J. (1995). His money, her money: Recent research on financial organisation in marriage. Journal of Economic Psychology, 16(3), 361-376. doi:https://doi.org/10.1016/0167-4870(95)00015-G

Pasha, A. (2017). Regional perspectives on the multidimensional poverty index. World Development, 94, $268-285$.

Rahman, S. (2000). Women's employment in Bangladesh agriculture: Composition, determinants and scope. Journal of Rural Studies, 16(4), 497-507.

Schuler, S.R., Hashemi, S.M., \& Riley, A.P. (1997). The influence of women's changing roles and status in Bangladesh's fertility transition: Evidence from a study of credit programs and contraceptive use. World Development, 25(4), 563-575.

Sinha, B., Jha, S., \& Negi, N.S. (2012). Migration and empowerment: The experience of women in households in India where migration of a husband has occurred. Journal of Gender Studies, 21(1), 61-76. https://doi.org/10.1080/09589236.2012.639551

Stillwell, J., \& Thomas, M. (2016). How far do internal migrants really move? Demonstrating a new method for the estimation of intra-zonal distance. Regional Studies, Regional Science, 3(1), 28 47.

Taylor, J.E., \& Mora, J. (2006). Does migration reshape expenditures in rural households? Evidence from Mexico. World Bank Policy Research Working Paper 3842.

Ullah, A.A. (2017). Male Migration and 'Left-behind' Women: Bane or Boon? Environment and Urbanization ASIA, 8(1), 59-73.

UN Women. (2018). Facts and figures: Economic empowerment. Retrieved from https://www.unwomen.org/en/what-we-do/economic-empowerment/facts-and-figures

Vullnetari, J. (2012). Women and Migration in Albania: A View from the Village. International Migration, 50, 169-188. https://doi.org/10.1111/j.1468-2435.2009.00569.x

Wooldridge, J. (2008). Introductory Econometrics (4th ed). Retrieved from http://fmwww.bc.edu/ECC/F2012/228/EC228.f2012.nn15.pdf

Yount, K.M., Miedema, S.S., Martin, C.C., Crandall, A., \& Naved, R.T. (2016). Men's Coercive Control, Partner Violence Perpetration, and Life Satisfaction in Bangladesh. Sex Roles, 74(9), 450-463. doi:10.1007/s11199-016-0584-3 


\section{APPENDIX A}

TABLE A1

SUMMARY STATISTICS

\begin{tabular}{|c|c|c|c|c|c|}
\hline Variable & Observation & Mean & Std. Dev. & Min & Max \\
\hline \multicolumn{6}{|l|}{ Dependent Variables: } \\
\hline Migration & 59,228 & 0.038428 & 0.1922283 & 0 & 1 \\
\hline International migration & 59,228 & 0.011397 & 0.1061459 & 0 & 1 \\
\hline Internal migration & 59,228 & 0.027082 & 0.1623232 & 0 & 1 \\
\hline Left households & 59,228 & 0.058283 & 0.2342802 & 0 & 1 \\
\hline Physical violence & 28,761 & 0.13494 & 0.341665 & 0 & 1 \\
\hline Emotional violence & 28,761 & 0.002051 & 0.045247 & 0 & 1 \\
\hline No market & 28,761 & 0.790515 & 0.406948 & 0 & 1 \\
\hline No friends/relatives & 28,761 & 0.783526 & 0.411848 & 0 & 1 \\
\hline No ngo & 28,761 & 0.719516 & 0.449244 & 0 & 1 \\
\hline $\begin{array}{l}\text { Does not participate in } \\
\text { production }\end{array}$ & 28,761 & 0.778172 & 0.415483 & 0 & 1 \\
\hline $\begin{array}{l}\text { Does not participate in } \\
\text { decision-making regarding } \\
\text { production }\end{array}$ & 28,761 & 0.800111 & 0.399924 & 0 & 1 \\
\hline No money to spend & 28,761 & 0.68426 & 0.25248 & 0 & 1 \\
\hline Not earning money & 28,761 & 0.92765 & 0.290107 & 0 & 1 \\
\hline $\begin{array}{l}\text { Not feeling comfortable to } \\
\text { speak in public }\end{array}$ & 28,761 & 0.171865 & 0.377269 & 0 & 1 \\
\hline \multicolumn{6}{|l|}{ Different measures: } \\
\hline Empowerment_AFM & 59,228 & 0.382975 & 0.0881457 & 0 & 0.933333 \\
\hline Empowerment_PCA & 59,228 & -0.0065 & 1.00464 & -4.59341 & 0.513245 \\
\hline Empowerment_MCA & 59,228 & -0.00634 & 1.004714 & -4.08637 & 0.502051 \\
\hline Empowerment_FAZ & 59,228 & -0.0065 & 1.00464 & -4.59341 & 0.513245 \\
\hline \multicolumn{6}{|l|}{ Controls: } \\
\hline Age & 54,928 & 27.13913 & 20.11816 & 0 & 123 \\
\hline Workplace in urban & 54,887 & 0.116968 & 0.3213846 & 0 & 1 \\
\hline $\begin{array}{l}\text { Total value of asset bought } \\
\text { at the time of marriage }\end{array}$ & 59,228 & 7.165732 & 3.991738 & 0 & 14.51762 \\
\hline Education: primary & 54,928 & 0.354555 & 0.4783826 & 0 & 1 \\
\hline Education: secondary & 54,928 & 0.186735 & 0.3897025 & 0 & 1 \\
\hline Education: SSC/HSC & 54,928 & 0.068908 & 0.2533006 & 0 & 1 \\
\hline $\begin{array}{l}\text { Education: graduate } \\
\text { occupation }\end{array}$ & 54,928 & 0.010796 & 0.1033421 & 0 & 1 \\
\hline occupation: Salaried worker & 54,926 & 0.02345 & 0.1513283 & 0 & 1 \\
\hline occupation: Self employed & 54,926 & 0.045825 & 0.2091079 & 0 & 1 \\
\hline Occupation: trader & 54,926 & 0.038634 & 0.1927223 & 0 & 1 \\
\hline
\end{tabular}




\begin{tabular}{lccccc}
\hline $\begin{array}{l}\text { Occupation: Production } \\
\text { food }\end{array}$ & 54,926 & 0.004479 & 0.0667741 & 0 & 1 \\
$\begin{array}{l}\text { Occupation: Livestock } \\
\text { Poultry }\end{array}$ & 54,926 & 0.000437 & 0.020899 & 0 & 1 \\
$\begin{array}{l}\text { Occupation: Farming } \\
\text { Occupation: non-earning }\end{array}$ & 54,926 & 0.20737 & 0.4054265 & 0 & 1 \\
Income (monthly/log) & 54,926 & 0.615519 & 0.4864768 & 0 & 1 \\
Wealth Index & 51,982 & 8.520685 & 1.301003 & 1.098612 & 12.61154 \\
Marital status: married & 59,227 & 0.100884 & 0.9895988 & -2.872 & 4.146181 \\
Marital status: widow & 54,928 & 0.474567 & 0.4993573 & 0 & 1 \\
Marital status: divorced & 54,928 & 0.049574 & 0.2170651 & 0 & 1 \\
Marital status: separated & 54,928 & 0.003095 & 0.0555467 & 0 & 1 \\
Instruments & 54,928 & 0.004533 & 0.0671769 & 0 & 1 \\
Migration network & & & & & \\
Distance from origins to & 59,194 & 0.025151 & 0.0154706 & 0 & 0.437916 \\
destinations & & & & & 13205 \\
\hline
\end{tabular}




\section{APPENDIX B: THE ENTIRE REGRESSION RESULTS}

TABLE B1

FIRST STAGE REGRESSION

\begin{tabular}{|c|c|c|c|}
\hline VARIABLES & $\begin{array}{c}(1) \\
\text { migration }\end{array}$ & $\begin{array}{l}(2) \\
\text { internal migration }\end{array}$ & $\begin{array}{l}(3) \\
\text { international migration }\end{array}$ \\
\hline Migration network & $\begin{array}{c}21.0 * * * \\
{[17.0]}\end{array}$ & $\begin{array}{c}14.0 * * * \\
{[8.57]}\end{array}$ & $\begin{array}{c}7.60 * * * \\
{[4.02]}\end{array}$ \\
\hline $\begin{array}{l}\text { Distance from origin to } \\
\text { destination }\end{array}$ & $\begin{array}{c}0.0024 * * * \\
\quad[10.1]\end{array}$ & $\begin{array}{l}0.0020 * * * \\
{[6.90]}\end{array}$ & $\begin{array}{c}0.00046^{*} \\
{[1.86]}\end{array}$ \\
\hline Age & $\begin{array}{c}0.00075 \\
{[1.27]}\end{array}$ & $\begin{array}{c}0.000061 \\
{[0.046]}\end{array}$ & $\begin{array}{c}0.00062 \\
{[0.49]}\end{array}$ \\
\hline Number of children & $\begin{array}{l}-0.0047 \\
{[-1.53]}\end{array}$ & $\begin{array}{l}0.0026 \\
{[0.42]}\end{array}$ & $\begin{array}{l}-0.0058 \\
{[-0.85]}\end{array}$ \\
\hline Workplace (urban) & $\begin{array}{l}0.0010 \\
{[0.21]}\end{array}$ & $\begin{array}{c}-0.0044 \\
{[-0.61]}\end{array}$ & $\begin{array}{l}0.0040 \\
{[0.49]}\end{array}$ \\
\hline $\begin{array}{l}\text { total value of asset bought } \\
\text { at the time of marriage }\end{array}$ & $\begin{array}{c}-0.00063 \\
{[-1.45]}\end{array}$ & $\begin{array}{c}0.0017 * \\
{[1.67]}\end{array}$ & $\begin{array}{c}-0.0024 * * \\
{[-2.02]}\end{array}$ \\
\hline Level of education & $\begin{array}{c}-0.00019 \\
{[-0.76]}\end{array}$ & $\begin{array}{c}-0.00090 \\
{[-1.11]}\end{array}$ & $\begin{array}{c}0.000077 \\
{[0.089]}\end{array}$ \\
\hline Occupation & $\begin{array}{c}-0.00014 \\
{[-0.39]}\end{array}$ & $\begin{array}{c}-0.00056 \\
{[-0.86]}\end{array}$ & $\begin{array}{c}0.000074 \\
{[0.10]}\end{array}$ \\
\hline Income (log) & $\begin{array}{c}0.0020 \\
{[0.91]}\end{array}$ & $\begin{array}{l}-0.0022 \\
{[-0.49]}\end{array}$ & $\begin{array}{l}0.0019 \\
{[0.38]}\end{array}$ \\
\hline Wealth index & $\begin{array}{l}-0.0055 \\
{[-1.54]}\end{array}$ & $\begin{array}{l}-0.0024 \\
{[-0.30]}\end{array}$ & $\begin{array}{l}-0.0035 \\
{[-0.41]}\end{array}$ \\
\hline Marital status & $\begin{array}{c}-0.0016^{*} \\
{[-1.94]}\end{array}$ & $\begin{array}{l}-0.0012 \\
{[-0.50]}\end{array}$ & $\begin{array}{c}-0.00032 \\
{[-0.14]}\end{array}$ \\
\hline Observations & 23,423 & 23,423 & 23,423 \\
\hline R-squared & 0.054 & 0.11 & 0.12 \\
\hline
\end{tabular}




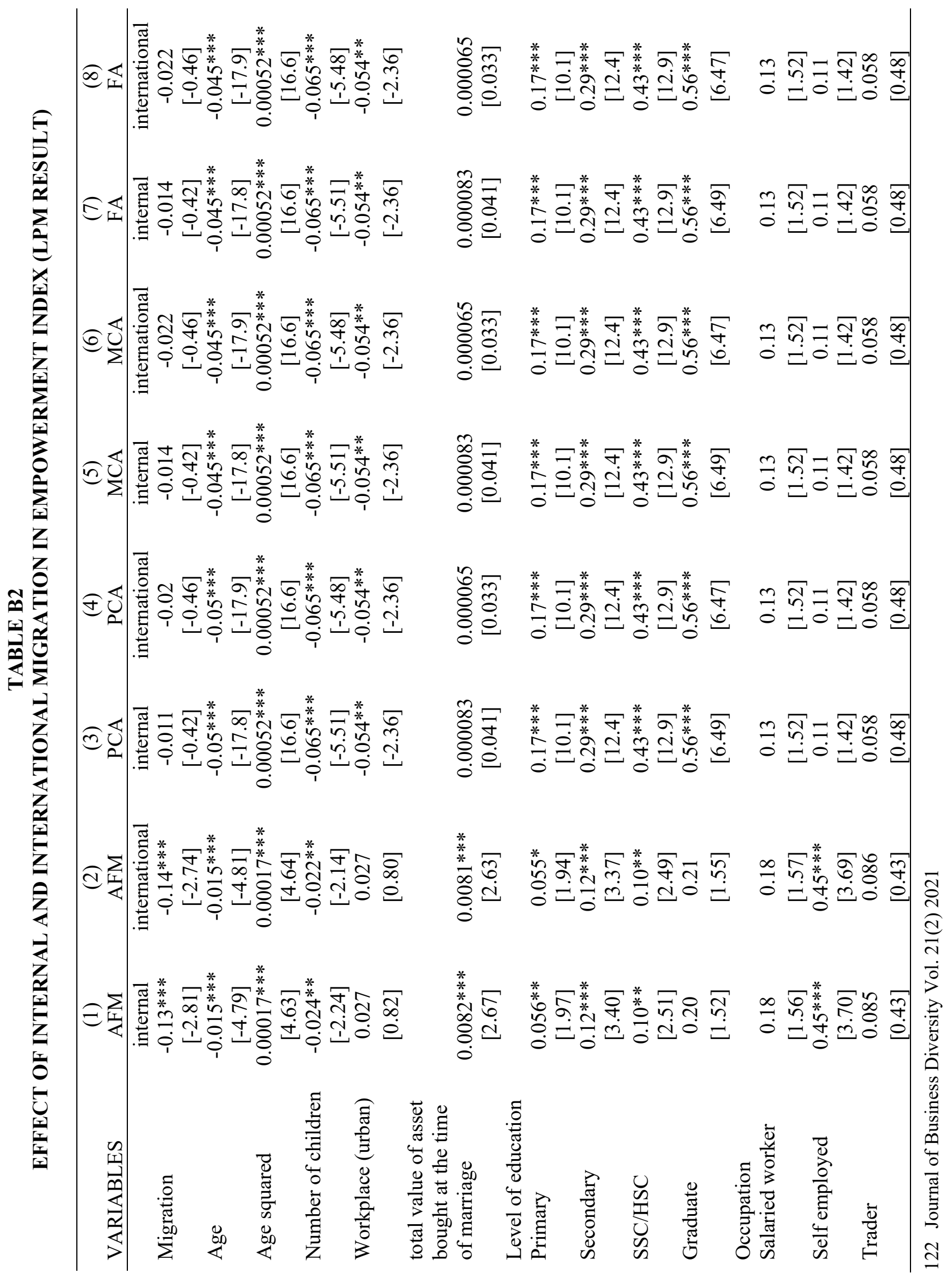




\begin{tabular}{|c|c|c|c|c|c|c|c|c|}
\hline Production food & $\begin{array}{c}0.65 * * * \\
{[4.65]}\end{array}$ & $\begin{array}{c}0.66^{* * *} \\
{[4.75]}\end{array}$ & $\begin{array}{l}0.18^{*} \\
{[1.67]}\end{array}$ & $\begin{array}{l}0.18^{*} \\
{[1.68]}\end{array}$ & $\begin{array}{l}0.18^{*} \\
{[1.67]}\end{array}$ & $\begin{array}{c}0.18^{*} \\
{[1.68]}\end{array}$ & $\begin{array}{l}0.18^{*} \\
{[1.67]}\end{array}$ & $\begin{array}{c}0.18^{*} \\
{[1.68]}\end{array}$ \\
\hline Livestock Poultry & 1.27 & 1.25 & -0.085 & -0.089 & -0.085 & -0.089 & -0.085 & -0.089 \\
\hline Farming & $\begin{array}{c}{[1.00]} \\
0.60 * * * \\
{[6.85]}\end{array}$ & $\begin{array}{c}{[0.98]} \\
0.60 * * * \\
{[6.88]}\end{array}$ & $\begin{array}{c}{[-0.10]} \\
0.050 \\
{[0.74]}\end{array}$ & $\begin{array}{c}{[-0.11]} \\
0.050 \\
{[0.74]}\end{array}$ & $\begin{array}{c}{[-0.10]} \\
0.050 \\
{[0.74]}\end{array}$ & $\begin{array}{c}{[-0.11]} \\
0.050 \\
{[0.74]}\end{array}$ & $\begin{array}{c}{[-0.10]} \\
0.050 \\
{[0.74]}\end{array}$ & $\begin{array}{c}{[-0.11]} \\
0.050 \\
{[0.74]}\end{array}$ \\
\hline $\begin{array}{l}\text { Non-earning } \\
\text { occupation }\end{array}$ & $\begin{array}{c}0.98 * * * \\
{[13.9]}\end{array}$ & $\begin{array}{c}0.99 * * * \\
{[13.9]}\end{array}$ & $\begin{array}{c}0.41 * * * \\
{[8.42]}\end{array}$ & $\begin{array}{c}0.41 * * * \\
{[8.48]}\end{array}$ & $\begin{array}{c}0.41 * * * \\
{[8.42]}\end{array}$ & $\begin{array}{c}0.41 * * * \\
{[8.48]}\end{array}$ & $\begin{array}{c}0.41 * * * \\
{[8.42]}\end{array}$ & $\begin{array}{c}0.41 * * * \\
{[8.48]}\end{array}$ \\
\hline Income (log) & $\begin{array}{c}0.023 * * \\
{[2.26]}\end{array}$ & $\begin{array}{c}0.024 * * \\
{[2.21]}\end{array}$ & $\begin{array}{l}0.0051 \\
{[0.63]}\end{array}$ & $\begin{array}{c}0.0049 \\
{[0.62]}\end{array}$ & $\begin{array}{l}0.0051 \\
{[0.63]}\end{array}$ & $\begin{array}{c}0.0049 \\
{[0.62]}\end{array}$ & $\begin{array}{c}0.0051 \\
{[0.63]}\end{array}$ & $\begin{array}{c}0.0049 \\
{[0.62]}\end{array}$ \\
\hline Wealth index & $\begin{array}{c}-0.092 * * * \\
{[-6.08]}\end{array}$ & $\begin{array}{c}-0.090 * * * \\
{[-5.85]}\end{array}$ & $\begin{array}{c}0.036^{* * *} \\
{[3.31]}\end{array}$ & $\begin{array}{c}0.036^{* * *} \\
{[3.47]}\end{array}$ & $\begin{array}{c}0.036^{* * *} \\
{[3.31]}\end{array}$ & $\begin{array}{c}0.036^{* * *} \\
{[3.47]}\end{array}$ & $\begin{array}{c}0.036^{* * *} \\
{[3.31]}\end{array}$ & $\begin{array}{c}0.036^{* * *} \\
{[3.47]}\end{array}$ \\
\hline Marital status & & & & & & & & \\
\hline Married & $\begin{array}{c}0.18 * * * \\
{[3.88]}\end{array}$ & $\begin{array}{c}0.18 * * * \\
{[3.96]}\end{array}$ & $\begin{array}{c}-0.83 * * * \\
{[-21.6]}\end{array}$ & $\begin{array}{c}-0.83 * * * \\
{[-21.5]}\end{array}$ & $\begin{array}{c}-0.83 * * * \\
{[-21.6]}\end{array}$ & $\begin{array}{c}-0.83 * * * \\
{[-21.5]}\end{array}$ & $\begin{array}{c}-0.83 * * * \\
{[-21.6]}\end{array}$ & $\begin{array}{c}-0.83 * * * \\
{[-21.5]}\end{array}$ \\
\hline Widow/widower & $\begin{array}{c}-0.18 * * * \\
{[-3.23]}\end{array}$ & $\begin{array}{c}-0.18 * * * \\
{[-3.17]}\end{array}$ & $\begin{array}{c}-0.15 * * * \\
{[-2.93]}\end{array}$ & $\begin{array}{c}-0.15 * * * \\
{[-2.92]}\end{array}$ & $\begin{array}{c}-0.15 * * * \\
{[-2.93]}\end{array}$ & $\begin{array}{c}-0.15 * * * \\
{[-2.92]}\end{array}$ & $\begin{array}{c}-0.15 * * * \\
{[-2.93]}\end{array}$ & $\begin{array}{c}-0.15 * * * \\
{[-2.92]}\end{array}$ \\
\hline Divorced & $\begin{array}{c}0.14 \\
{[1.11]}\end{array}$ & $\begin{array}{c}0.15 \\
{[1.15]}\end{array}$ & $\begin{array}{c}0.15 \\
{[1.52]}\end{array}$ & $\begin{array}{c}0.15 \\
{[1.52]}\end{array}$ & $\begin{array}{c}0.15 \\
{[1.52]}\end{array}$ & $\begin{array}{c}0.15 \\
{[1.52]}\end{array}$ & $\begin{array}{c}0.15 \\
{[1.52]}\end{array}$ & $\begin{array}{c}0.15 \\
{[1.52]}\end{array}$ \\
\hline Separated/deserted & $\begin{array}{c}-0.16 \\
{[-1.57]}\end{array}$ & $\begin{array}{c}-0.15 \\
{[-1.49]}\end{array}$ & $\begin{array}{c}-0.14 \\
{[-1.57]}\end{array}$ & $\begin{array}{c}-0.14 \\
{[-1.55]}\end{array}$ & $\begin{array}{c}-0.14 \\
{[-1.57]}\end{array}$ & $\begin{array}{c}-0.14 \\
{[-1.55]}\end{array}$ & $\begin{array}{c}-0.14 \\
{[-1.57]}\end{array}$ & $\begin{array}{c}-0.14 \\
{[-1.55]}\end{array}$ \\
\hline Constant & $\begin{array}{c}-1.14 * * * \\
{[-9.88]}\end{array}$ & $\begin{array}{c}-1.16 * * * \\
{[-10.1]}\end{array}$ & $\begin{array}{c}-0.61 * * * \\
{[-6.27]}\end{array}$ & $\begin{array}{c}-0.61 * * * \\
{[-6.19]}\end{array}$ & $\begin{array}{c}-0.61 * * * \\
{[-6.27]}\end{array}$ & $\begin{array}{c}-0.61 * * * \\
{[-6.19]}\end{array}$ & $\begin{array}{c}-0.61 * * * \\
{[-6.27]}\end{array}$ & $\begin{array}{c}-0.61 * * * \\
{[-6.19]}\end{array}$ \\
\hline Observations & 24,084 & 24,084 & 24,084 & 24,084 & 24,084 & 24,084 & 24,084 & 24,084 \\
\hline R-squared & 0.12 & 0.12 & 0.48 & 0.48 & 0.48 & 0.48 & 0.48 & 0.48 \\
\hline
\end{tabular}


TABLE B3

EFFECT OF INTERNAL AND INTERNATIONAL MIGRATION IN EMPOWERMENT INDEX (IV RESULT)

\begin{tabular}{|c|c|c|c|c|c|c|c|c|}
\hline VARIABLES & $\begin{array}{c}(1) \\
\text { AFM }\end{array}$ & $\begin{array}{c}(2) \\
\text { AFM } \\
\end{array}$ & $\begin{array}{c}(3) \\
\text { PCA }\end{array}$ & $\begin{array}{c}(4) \\
\text { PCA } \\
\end{array}$ & $\begin{array}{c}(5) \\
\text { MCA }\end{array}$ & $\begin{array}{c}(6) \\
\mathrm{MCA} \\
\end{array}$ & $\begin{array}{l}(7) \\
\text { FA }\end{array}$ & $\begin{array}{l}(8) \\
\text { FA } \\
\end{array}$ \\
\hline Migration & $\begin{array}{c}\text { internal } \\
-0.14 * * \\
{[-1.98]}\end{array}$ & $\begin{array}{c}\text { international } \\
-0.43^{*} \\
{[-1.90]}\end{array}$ & $\begin{array}{c}\text { internal } \\
-0.022 \\
{[-0.53]}\end{array}$ & $\begin{array}{c}\text { international } \\
-0.082 \\
{[-0.69]}\end{array}$ & $\begin{array}{c}\text { internal } \\
-0.011 \\
{[-0.21]}\end{array}$ & $\begin{array}{c}\text { international } \\
-0.042 \\
{[-0.30]}\end{array}$ & $\begin{array}{c}\text { internal } \\
-0.029 \\
{[-0.53]}\end{array}$ & $\begin{array}{c}\text { international } \\
-0.094 \\
{[-0.69]}\end{array}$ \\
\hline Age & $\begin{array}{c}-0.0052 \\
{[-0.97]}\end{array}$ & $\begin{array}{c}-0.0052 \\
{[-0.97]}\end{array}$ & $\begin{array}{c}-0.14 * * * \\
{[-31.1]}\end{array}$ & $\begin{array}{c}-0.14 * * * \\
{[-31.1]}\end{array}$ & $\begin{array}{c}-0.097 * * * \\
{[-27.0]}\end{array}$ & $\begin{array}{c}-0.097 * * * \\
{[-27.1]}\end{array}$ & $\begin{array}{c}-0.11 * * * \\
{[-31.1]}\end{array}$ & $\begin{array}{c}-0.11 * * * \\
{[-31.1]}\end{array}$ \\
\hline Age squared & $\begin{array}{c}0.000067 \\
{[1.17]}\end{array}$ & $\begin{array}{c}0.000067 \\
{[1.17]}\end{array}$ & $\begin{array}{c}0.0013 * * * \\
{[27.3]}\end{array}$ & $\begin{array}{c}0.0013 * * * \\
{[27.3]}\end{array}$ & $\begin{array}{c}0.0011 * * * \\
{[24.6]}\end{array}$ & $\begin{array}{c}0.0011 * * * \\
{[24.6]}\end{array}$ & $\begin{array}{c}0.0013 * * * \\
{[27.3]}\end{array}$ & $\begin{array}{c}0.0013 * * * \\
{[27.3]}\end{array}$ \\
\hline Number of children & $\begin{array}{c}-0.041 * \\
{[-1.70]}\end{array}$ & $\begin{array}{l}-0.041 \\
{[-1.64]}\end{array}$ & $\begin{array}{c}0.047 * * \\
{[2.51]}\end{array}$ & $\begin{array}{c}0.047 * * \\
{[2.51]}\end{array}$ & $\begin{array}{l}0.038^{*} \\
{[1.84]}\end{array}$ & $\begin{array}{l}0.038^{*} \\
{[1.83]}\end{array}$ & $\begin{array}{c}0.047 * * \\
{[2.51]}\end{array}$ & $\begin{array}{c}0.047 * * \\
{[2.51]}\end{array}$ \\
\hline Workplace (urban) & $\begin{array}{l}0.051 \\
{[1.24]}\end{array}$ & $\begin{array}{l}0.053 \\
{[1.27]}\end{array}$ & $\begin{array}{l}0.11 * * \\
{[2.51]}\end{array}$ & $\begin{array}{l}0.11 * * \\
{[2.52]}\end{array}$ & $\begin{array}{c}0.12 * * * \\
{[2.71]}\end{array}$ & $\begin{array}{c}0.12 * * * \\
{[2.71]}\end{array}$ & $\begin{array}{l}0.11 * * \\
{[2.51]}\end{array}$ & $\begin{array}{l}0.11 * * \\
{[2.52]}\end{array}$ \\
\hline $\begin{array}{l}\text { total value of asset } \\
\text { bought at the time of } \\
\text { marriage }\end{array}$ & $\begin{array}{c}0.0039 \\
{[0.75]}\end{array}$ & $\begin{array}{c}0.0029 \\
{[0.53]}\end{array}$ & $\begin{array}{c}-0.0011 \\
{[-0.32]}\end{array}$ & $\begin{array}{c}-0.0013 \\
{[-0.38]}\end{array}$ & $\begin{array}{c}-0.00061 \\
{[-0.19]}\end{array}$ & $\begin{array}{c}-0.00070 \\
{[-0.22]}\end{array}$ & $\begin{array}{c}-0.0011 \\
{[-0.32]}\end{array}$ & $\begin{array}{c}-0.0013 \\
{[-0.38]}\end{array}$ \\
\hline Level of education & $\begin{array}{c}0.083 * * * \\
{[5.53]}\end{array}$ & $\begin{array}{c}0.083 * * * \\
{[5.56]}\end{array}$ & $\begin{array}{c}0.22 * * * \\
{[15.4]}\end{array}$ & $\begin{array}{c}0.22 * * * \\
{[15.5]}\end{array}$ & $\begin{array}{c}0.18 * * * \\
{[15.0]}\end{array}$ & $\begin{array}{c}0.18 * * * \\
{[15.1]}\end{array}$ & $\begin{array}{c}0.22 * * * \\
{[15.4]}\end{array}$ & $\begin{array}{c}0.22 * * * \\
{[15.5]}\end{array}$ \\
\hline Occupation & $\begin{array}{c}0.13 * * * \\
{[11.9]}\end{array}$ & $\begin{array}{c}0.13 * * * \\
{[11.8]}\end{array}$ & $\begin{array}{c}0.080 * * * \\
{[9.02]}\end{array}$ & $\begin{array}{c}0.080 * * * \\
{[9.01]}\end{array}$ & $\begin{array}{c}0.061 * * * \\
{[7.35]}\end{array}$ & $\begin{array}{c}0.061 * * * \\
{[7.34]}\end{array}$ & $\begin{array}{c}0.080 * * * \\
{[9.02]}\end{array}$ & $\begin{array}{c}0.080 * * * \\
{[9.01]}\end{array}$ \\
\hline Income (log) & $\begin{array}{c}0.0075 \\
{[0.42]}\end{array}$ & $\begin{array}{l}0.0090 \\
{[0.51]}\end{array}$ & $\begin{array}{c}-0.0032 \\
{[-0.27]}\end{array}$ & $\begin{array}{c}-0.0029 \\
{[-0.25]}\end{array}$ & $\begin{array}{r}-0.0077 \\
{[-0.68]}\end{array}$ & $\begin{array}{c}-0.0076 \\
{[-0.68]}\end{array}$ & $\begin{array}{c}-0.0032 \\
{[-0.27]}\end{array}$ & $\begin{array}{c}-0.0029 \\
{[-0.25]}\end{array}$ \\
\hline Wealth index & $\begin{array}{l}-0.060 \\
{[-1.39]}\end{array}$ & $\begin{array}{l}-0.058 \\
{[-1.34]}\end{array}$ & $\begin{array}{l}-0.017 \\
{[-0.71]}\end{array}$ & $\begin{array}{l}-0.016 \\
{[-0.69]}\end{array}$ & $\begin{array}{l}-0.019 \\
{[-0.74]}\end{array}$ & $\begin{array}{l}-0.019 \\
{[-0.74]}\end{array}$ & $\begin{array}{l}-0.017 \\
{[-0.71]}\end{array}$ & $\begin{array}{l}-0.016 \\
{[-0.69]}\end{array}$ \\
\hline Marital status & $\begin{array}{c}-0.089 * * * \\
{[-2.81]}\end{array}$ & $\begin{array}{c}-0.088 * * * \\
{[-2.80]}\end{array}$ & $\begin{array}{c}0.070 * * * \\
{[3.14]}\end{array}$ & $\begin{array}{c}0.070 * * * \\
{[3.14]}\end{array}$ & $\begin{array}{c}0.089 * * * \\
{[4.84]}\end{array}$ & $\begin{array}{c}0.089 * * * \\
{[4.84]}\end{array}$ & $\begin{array}{c}0.070 * * * \\
{[3.14]}\end{array}$ & $\begin{array}{c}0.070 * * * \\
{[3.14]}\end{array}$ \\
\hline $\begin{array}{l}\text { Observations } \\
\text { R-squared } \\
\text { First stage F-stat }\end{array}$ & $\begin{array}{c}23,423 \\
0.03 \\
356\end{array}$ & $\begin{array}{c}23,423 \\
0.03 \\
32\end{array}$ & $\begin{array}{c}23,423 \\
0.48 \\
356\end{array}$ & $\begin{array}{c}23,423 \\
0.48 \\
32\end{array}$ & $\begin{array}{c}23,423 \\
0.52 \\
356\end{array}$ & $\begin{array}{c}23,423 \\
0.52 \\
32\end{array}$ & $\begin{array}{c}23,423 \\
0.48 \\
356\end{array}$ & $\begin{array}{c}23,423 \\
0.48 \\
32\end{array}$ \\
\hline Sargan $\mathrm{J}$ statistics & 0.15 & 0.16 & 0.47 & 0.52 & 0.64 & 0.67 & 0.47 & 0.52 \\
\hline
\end{tabular}

Note: Robust t-statistics are in brackets, ***, ** and * denote 1, 5 and 10 percent level of significance, respectively. All regressions include other controls, and woman fixed effects. Also, standard errors are clustered at district level. 
TABLE B4

EFFECT OF MIGRATION OF A MEMBER ON WOMEN'S EMPOWERMENT INDICATORS (LPM RESULT)

\begin{tabular}{|c|c|c|c|c|c|c|c|c|c|c|}
\hline VARIABLES & $\begin{array}{l}\text { domestic } \\
\text { violence }\end{array}$ & $\begin{array}{l}\text { emotional } \\
\text { violence }\end{array}$ & no market & $\begin{array}{l}\text { no } \\
\text { friends/ } \\
\text { relatives }\end{array}$ & no ngo & $\begin{array}{l}\text { production } \\
\text { activity }\end{array}$ & $\begin{array}{l}\text { production } \\
\text { decision }\end{array}$ & $\begin{array}{l}\text { no money } \\
\text { to spend }\end{array}$ & $\begin{array}{l}\text { not earning } \\
\text { money }\end{array}$ & $\begin{array}{l}\quad(10) \\
\text { not } \\
\text { comfortable } \\
\text { to speak in } \\
\text { front of } \\
\text { public }\end{array}$ \\
\hline Migration & $\begin{array}{c}-0.027 * * * \\
{[-2.82]}\end{array}$ & $\begin{array}{c}-0.0013 * \\
{[-1.71]}\end{array}$ & $\begin{array}{l}-0.010 \\
{[-0.85]}\end{array}$ & $\begin{array}{c}0.0011 \\
{[0.10]}\end{array}$ & $\begin{array}{l}-0.013 \\
{[-0.86]}\end{array}$ & $\begin{array}{c}-0.11 * * * \\
{[-4.41]}\end{array}$ & $\begin{array}{c}-0.11 * * * \\
{[-4.65]}\end{array}$ & $\begin{array}{c}0.0050 \\
{[0.82]}\end{array}$ & $\begin{array}{c}0.023 * * \\
{[2.57]}\end{array}$ & $\begin{array}{c}0.086 * * * \\
{[5.23]}\end{array}$ \\
\hline Age & $\begin{array}{c}0.017 * * * \\
{[4.03]}\end{array}$ & $\begin{array}{c}0.00044 \\
{[1.15]}\end{array}$ & $\begin{array}{c}0.012 * * \\
{[2.13]}\end{array}$ & $\begin{array}{c}0.0097^{*} \\
{[1.72]}\end{array}$ & $\begin{array}{l}0.0038 \\
{[0.58]}\end{array}$ & $\begin{array}{c}-0.0095 \\
{[-1.50]}\end{array}$ & $\begin{array}{c}-0.0050 \\
{[-0.88]}\end{array}$ & $\begin{array}{c}0.021 * * * \\
{[7.03]}\end{array}$ & $\begin{array}{c}0.019 * * * \\
{[5.06]}\end{array}$ & $\begin{array}{c}0.020 * * * \\
{[3.90]}\end{array}$ \\
\hline $\begin{array}{l}\text { Number of } \\
\text { children }\end{array}$ & $\begin{array}{c}0.0098 * * * \\
{[4.39]}\end{array}$ & $\begin{array}{c}-0.00016 \\
{[-0.60]}\end{array}$ & $\begin{array}{c}0.015 * * * \\
{[5.33]}\end{array}$ & $\begin{array}{c}0.019 * * * \\
{[7.58]}\end{array}$ & $\begin{array}{c}0.016^{* * *} \\
{[5.32]}\end{array}$ & $\begin{array}{c}-0.0024 \\
{[-0.67]}\end{array}$ & $\begin{array}{c}-0.0035 \\
{[-1.05]}\end{array}$ & $\begin{array}{c}-0.0047 * * * \\
{[-3.00]}\end{array}$ & $\begin{array}{c}-0.0059 * * * \\
{[-3.09]}\end{array}$ & $\begin{array}{c}-0.0030 \\
{[-1.18]}\end{array}$ \\
\hline $\begin{array}{l}\text { Workplace } \\
\text { (urban) }\end{array}$ & $\begin{array}{l}0.0036 \\
{[0.43]}\end{array}$ & $\begin{array}{c}-0.00011 \\
{[-0.11]}\end{array}$ & $\begin{array}{c}-0.019 * * * \\
{[-2.76]}\end{array}$ & $\begin{array}{c}-0.0054 \\
{[-0.62]}\end{array}$ & $\begin{array}{c}-0.0071 \\
{[-0.84]}\end{array}$ & $\begin{array}{c}-0.0046 \\
{[-0.36]}\end{array}$ & $\begin{array}{l}-0.0010 \\
{[-0.084]}\end{array}$ & $\begin{array}{c}0.0095 \\
{[1.50]}\end{array}$ & $\begin{array}{c}0.020 * * * \\
{[2.71]}\end{array}$ & $\begin{array}{c}0.021 * * \\
{[2.10]}\end{array}$ \\
\hline $\begin{array}{l}\text { total value of } \\
\text { asset bought at } \\
\text { the time of } \\
\text { marriage (log) }\end{array}$ & $\begin{array}{c}0.0066 * * * \\
{[7.69]}\end{array}$ & $\begin{array}{c}0.000036 \\
{[0.43]}\end{array}$ & $\begin{array}{l}0.0014 \\
{[1.31]}\end{array}$ & $\begin{array}{c}0.00036 \\
{[0.36]}\end{array}$ & $\begin{array}{c}0.0032 * * * \\
{[2.93]}\end{array}$ & $\begin{array}{c}0.0070 * * * \\
{[5.64]}\end{array}$ & $\begin{array}{c}0.0069 * * * \\
{[5.48]}\end{array}$ & $\begin{array}{c}-0.0037 * * * \\
{[-5.52]}\end{array}$ & $\begin{array}{c}-0.0023 * * * \\
{[-3.13]}\end{array}$ & $\begin{array}{c}-0.0066 * * * \\
{[-5.67]}\end{array}$ \\
\hline $\begin{array}{l}\text { Level of } \\
\text { education }\end{array}$ & & & & & & & & & & \\
\hline Primary & $\begin{array}{l}-0.0036 \\
{[-0.63]}\end{array}$ & $\begin{array}{c}-0.000081 \\
{[-0.11]}\end{array}$ & $\begin{array}{c}0.024 * * * \\
{[3.82]}\end{array}$ & $\begin{array}{c}0.019 * * * \\
{[3.24]}\end{array}$ & $\begin{array}{c}0.032 * * * \\
{[5.50]}\end{array}$ & $\begin{array}{c}0.031 * * * \\
{[5.31]}\end{array}$ & $\begin{array}{c}0.024 * * * \\
{[4.07]}\end{array}$ & $\begin{array}{c}-0.015 * * * \\
{[-3.62]}\end{array}$ & $\begin{array}{c}-0.013 * * \\
{[-2.41]}\end{array}$ & $\begin{array}{c}-0.028 * * * \\
{[-5.09]}\end{array}$ \\
\hline Secondary & $\begin{array}{c}-0.026 * * * \\
{[-2.66]}\end{array}$ & $\begin{array}{c}0.00012 \\
{[0.099]}\end{array}$ & $\begin{array}{c}0.060 * * * \\
{[6.93]}\end{array}$ & $\begin{array}{c}0.056^{* * *} \\
{[6.45]}\end{array}$ & $\begin{array}{c}0.066^{* * * *} \\
{[6.09]}\end{array}$ & $\begin{array}{c}0.045 * * * \\
{[4.96]}\end{array}$ & $\begin{array}{c}0.035 * * * \\
{[4.16]}\end{array}$ & $\begin{array}{c}-0.032 * * * \\
{[-6.30]}\end{array}$ & $\begin{array}{c}-0.021 * * * \\
{[-2.94]}\end{array}$ & $\begin{array}{c}-0.041 * * * \\
{[-5.81]}\end{array}$ \\
\hline $\mathrm{SSC} / \mathrm{HSC}$ & $\begin{array}{c}-0.062 * * * \\
{[-5.15]}\end{array}$ & $\begin{array}{c}-0.0026^{* *} \\
{[-2.52]}\end{array}$ & $\begin{array}{c}0.080 * * * \\
{[6.83]}\end{array}$ & $\begin{array}{c}0.083 * * * \\
{[6.49]}\end{array}$ & $\begin{array}{c}0.10 * * * \\
{[6.57]}\end{array}$ & $\begin{array}{c}0.056 * * * \\
{[5.35]}\end{array}$ & $\begin{array}{c}0.047 * * * \\
{[4.64]}\end{array}$ & $\begin{array}{c}-0.044 * * * \\
{[-8.72]}\end{array}$ & $\begin{array}{c}-0.035 * * * \\
{[-4.42]}\end{array}$ & $\begin{array}{c}-0.073 * * * \\
{[-7.41]}\end{array}$ \\
\hline Graduate & $\begin{array}{c}-0.12 * * * \\
{[-4.01]}\end{array}$ & $\begin{array}{c}-0.0036^{*} \\
{[-1.85]}\end{array}$ & $\begin{array}{c}0.13 * * * \\
{[3.78]}\end{array}$ & $\begin{array}{c}0.15 * * * \\
{[3.99]}\end{array}$ & $\begin{array}{c}0.16 * * * \\
{[3.97]}\end{array}$ & $\begin{array}{c}0.10 * * * \\
{[3.60]}\end{array}$ & $\begin{array}{c}0.085 * * * \\
{[3.07]}\end{array}$ & $\begin{array}{c}-0.028 \\
{[-1.40]}\end{array}$ & $\begin{array}{c}-0.054 * * * \\
{[-2.83]}\end{array}$ & $\begin{array}{c}-0.085 * * * \\
{[-3.59]}\end{array}$ \\
\hline
\end{tabular}




\begin{tabular}{|c|c|c|c|c|c|c|c|c|c|c|}
\hline \multicolumn{11}{|l|}{ Occupation } \\
\hline \multirow[t]{2}{*}{ Salaried worker } & $\begin{array}{l}0.018 \\
50.577\end{array}$ & $\begin{array}{l}0.0020 \\
50381\end{array}$ & 0.055 & 0.053 & 0.058 & $0.056^{*}$ & $\begin{array}{l}0.030 \\
50.021\end{array}$ & 0.00015 & 0.021 & -0.030 \\
\hline & {$[0.57]$} & {$[0.38]$} & [1.30] & {$[1.27]$} & {$[1.51]$} & $\begin{array}{l}{[1.71]} \\
0.086 * *\end{array}$ & $\begin{array}{c}{[0.92]} \\
0.98 * * *\end{array}$ & [0.013] & {$[1.40]$} & {$[-1.01]$} \\
\hline \multirow[t]{2}{*}{ Self employed } & -0.037 & 0.0053 & 0.040 & $0.069^{*}$ & 0.061 & $0.086^{* *}$ & $0.088^{* * *}$ & 0.026 & 0.019 & $0.058^{*}$ \\
\hline & {$[-1.05]$} & {$[0.82]$} & {$[1.00]$} & {$[1.84]$} & {$[1.56]$} & {$[2.40]$} & [2.60] & {$[1.53]$} & {$[1.20]$} & {$[1.73]$} \\
\hline \multirow[t]{2}{*}{ Trader } & -0.026 & 0.014 & 0.035 & 0.027 & 0.067 & 0.029 & -0.0080 & 0.0041 & -0.0030 & -0.023 \\
\hline & {$[-0.50]$} & {$[0.70]$} & {$[0.58]$} & {$[0.43]$} & [1.14] & {$[0.56]$} & {$[-0.16]$} & {$[0.18]$} & {$[-0.13]$} & {$[-0.49]$} \\
\hline \multirow[t]{2}{*}{ Production food } & -0.0062 & $-0.0051 *$ & $0.11^{*}$ & $0.16 * * *$ & $0.10^{* *}$ & 0.042 & 0.035 & 0.039 & 0.027 & $0.10^{*}$ \\
\hline & {$[-0.14]$} & {$[-1.76]$} & {$[1.94]$} & {$[3.65]$} & {$[2.14]$} & {$[0.90]$} & {$[0.80]$} & {$[1.35]$} & {$[1.23]$} & {$[1.73]$} \\
\hline \multirow[t]{2}{*}{ Livestock Poultry } & 0.36 & -0.0042 & -0.035 & $0.67 * * *$ & 0.096 & -0.21 & -0.27 & $-0.081 * * *$ & 0.25 & 0.38 \\
\hline & {$[1.34]$} & {$[-1.52]$} & {$[-0.11]$} & {$[20.1]$} & {$[0.34]$} & {$[-0.85]$} & [-1.09] & {$[-4.58]$} & [0.94] & {$[1.45]$} \\
\hline \multirow[t]{2}{*}{ Farming } & -0.015 & -0.0014 & $0.17 * * *$ & $0.21 * * *$ & $0.11 * * *$ & $-0.091 * * *$ & $-0.090 * * *$ & $0.099 * * *$ & $0.088 * * *$ & $0.14 * * *$ \\
\hline & {$[-0.54]$} & {$[-0.50]$} & {$[4.76]$} & [7.39] & {$[2.96]$} & {$[-2.82]$} & {$[-2.77]$} & [6.19] & [5.19] & {$[4.51]$} \\
\hline \multirow{2}{*}{$\begin{array}{l}\text { Non-earning } \\
\text { occupation }\end{array}$} & & & & & & & & & & \\
\hline & $\begin{array}{c}-0.068^{* *} \\
{[-2.47]}\end{array}$ & $\begin{array}{c}-0.0014 \\
{[-0.50]}\end{array}$ & $\begin{array}{c}0.30 * * * \\
{[12.1]}\end{array}$ & $\begin{array}{c}0.31 * * * \\
{[12.0]}\end{array}$ & $\begin{array}{c}0.27 * * * \\
{[11.0]}\end{array}$ & $\begin{array}{c}0.13 * * * \\
{[4.59]}\end{array}$ & $\begin{array}{c}0.12 * * * \\
{[4.72]}\end{array}$ & $\begin{array}{c}0.065^{* * *} * \\
{[5.20]}\end{array}$ & $\begin{array}{c}0.12 * * * \\
{[8.75]}\end{array}$ & $\begin{array}{l}0.0057 \\
{[0.21]}\end{array}$ \\
\hline \multirow[t]{2}{*}{ Income (log) } & $0.0078^{* * *}$ & -0.00040 & $0.018 * * *$ & $0.017 * * *$ & $0.018 * * *$ & 0.0053 & 0.0057 & -0.0029 & $-0.0040^{*}$ & $-0.013 * * *$ \\
\hline & [2.98] & [-1.64] & [5.76] & [5.04] & [5.93] & [1.07] & [1.18] & {$[-1.47]$} & {$[-1.92]$} & {$[-3.26]$} \\
\hline \multirow[t]{2}{*}{ Wealth index } & $-0.028 * * *$ & 0.00023 & 0.0079 & 0.0045 & $0.028 * * *$ & $0.033 * * *$ & $0.033 * * *$ & $-0.029 * * *$ & $-0.032 * * *$ & $-0.045^{* * *}$ \\
\hline & {$[-6.75]$} & {$[0.84]$} & {$[1.45]$} & {$[1.15]$} & [4.87] & {$[6.71]$} & [6.69] & {$[-10.7]$} & {$[-9.47]$} & [-10.9] \\
\hline \multicolumn{11}{|l|}{ Marital status } \\
\hline \multirow[t]{2}{*}{ Married } & $0.25 * * *$ & $0.0023 * * *$ & $-0.31 * * *$ & $-0.30 * * *$ & $-0.42 * * *$ & $-0.15 * * *$ & $-0.12 * * *$ & $0.085^{* * *}$ & $0.15^{* * *}$ & $0.17 * * *$ \\
\hline & [15.1] & [2.58] & {$[-18.0]$} & {$[-17.0]$} & [-17.3] & {$[-6.02]$} & {$[-5.49]$} & [10.1] & [11.2] & {$[12.9]$} \\
\hline \multirow[t]{2}{*}{ Widow/widower } & $-0.027 * *$ & -0.0011 & $-0.21 * * *$ & $-0.22 * * *$ & $-0.20 * * *$ & $0.033^{*}$ & 0.025 & $-0.050 * * *$ & -0.015 & -0.022 \\
\hline & {$[-2.32]$} & {$[-1.02]$} & {$[-10.6]$} & {$[-10.5]$} & {$[-8.26]$} & [1.73] & [1.46] & {$[-5.97]$} & {$[-1.46]$} & {$[-1.56]$} \\
\hline \multirow[t]{2}{*}{ Divorced } & -0.0017 & -0.0018 & $-0.097 * *$ & $-0.094 * *$ & $-0.094 * *$ & 0.057 & 0.041 & $-0.034 * *$ & 0.023 & -0.027 \\
\hline & {$[-0.083]$} & {$[-1.26]$} & {$[-2.06]$} & {$[-2.01]$} & {$[-2.00]$} & [1.58] & [1.19] & {$[-2.48]$} & [1.17] & {$[-0.88]$} \\
\hline \multirow{3}{*}{$\begin{array}{l}\text { Separated/ } \\
\text { deserted }\end{array}$} & & & & & & & & & & \\
\hline & $0.040^{*}$ & $0.022 *$ & $-0.26 * * *$ & $-0.25 * * *$ & $-0.23 * * *$ & 0.028 & 0.011 & $-0.049 * * *$ & -0.0010 & -0.0060 \\
\hline & [1.79] & [1.83] & {$[-6.81]$} & {$[-6.65]$} & {$[-5.74]$} & {$[0.80]$} & {$[0.31]$} & {$[-5.61]$} & {$[-0.082]$} & {$[-0.21]$} \\
\hline \multirow[t]{2}{*}{ Constant } & $-0.080^{*}$ & 0.0049 & $0.47 * * *$ & $0.46 * * *$ & $0.48 * * *$ & $0.70 * * *$ & $0.71 * * *$ & -0.011 & $-0.068 * * *$ & $0.18 * * *$ \\
\hline & {$[-1.88]$} & {$[1.46]$} & {$[11.3]$} & {$[10.0]$} & {$[11.7]$} & {$[11.3]$} & {$[12.1]$} & {$[-0.50]$} & [-2.99] & {$[3.44]$} \\
\hline Observations & 24,084 & 24,084 & 24,084 & 24,084 & 24,084 & 24,084 & 24,084 & 24,084 & 24,084 & 24,084 \\
\hline R-squared & 0.20 & 0.0028 & 0.24 & 0.22 & 0.35 & 0.18 & 0.16 & 0.093 & 0.11 & 0.18 \\
\hline
\end{tabular}

Note: Robust t-statistics are in brackets, ***, ** and * denote 1, 5 and 10 percent level of significance, respectively. All regressions include other controls, and woman fixed effects. Also, standard errors are clustered at district level. 
TABLE B5

EFFECT OF INTERNAL MIGRATION OF A MEMBER ON WOMEN'S EMPOWERMENT INDICATORS (LPM RESULT)

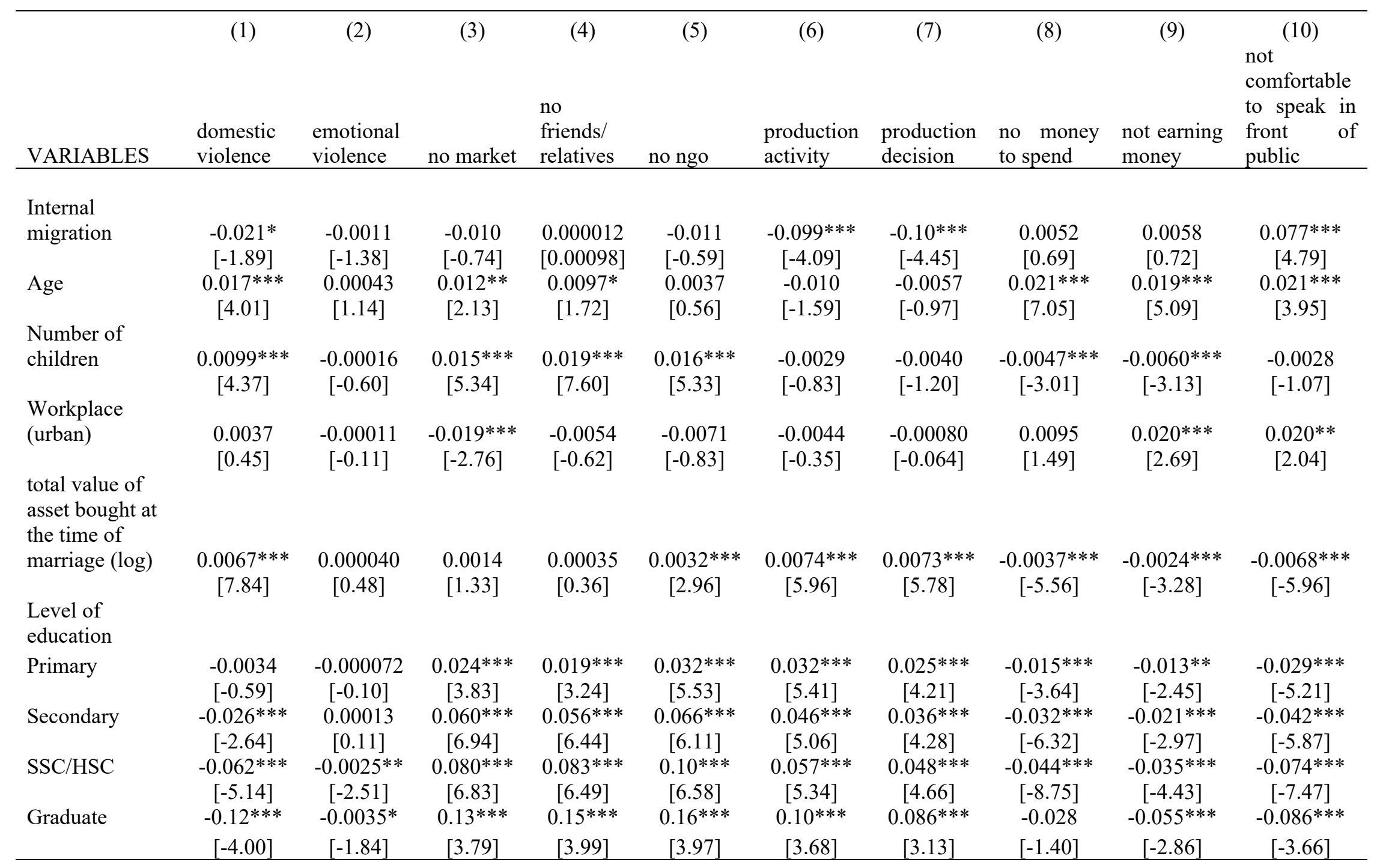




\begin{tabular}{|c|c|c|c|c|c|c|c|c|c|c|}
\hline \multicolumn{11}{|l|}{ Occupation } \\
\hline \multirow[t]{2}{*}{ Salaried worker } & 0.018 & 0.0020 & 0.055 & 0.053 & 0.058 & $0.057^{*}$ & 0.031 & 0.00013 & 0.020 & -0.030 \\
\hline & {$[0.58]$} & {$[0.38]$} & {$[1.30]$} & [1.27] & {$[1.51]$} & {$[1.74]$} & [0.94] & {$[0.011]$} & [1.37] & {$[-1.03]$} \\
\hline \multirow[t]{2}{*}{ Self employed } & -0.037 & 0.0053 & 0.040 & $0.069^{*}$ & 0.061 & $0.086^{* *}$ & $0.089 * * *$ & 0.026 & 0.019 & $0.057^{*}$ \\
\hline & {$[-1.03]$} & {$[0.82]$} & {$[1.00]$} & {$[1.84]$} & {$[1.56]$} & [2.41] & [2.62] & {$[1.53]$} & {$[1.16]$} & {$[1.71]$} \\
\hline \multirow[t]{2}{*}{ Trader } & -0.025 & 0.014 & 0.035 & 0.027 & 0.068 & 0.031 & -0.0060 & 0.0040 & -0.0040 & -0.024 \\
\hline & {$[-0.49]$} & {$[0.70]$} & {$[0.58]$} & {$[0.43]$} & {$[1.15]$} & {$[0.60]$} & {$[-0.12]$} & {$[0.18]$} & {$[-0.16]$} & {$[-0.53]$} \\
\hline \multirow[t]{2}{*}{ Production food } & -0.0065 & $-0.0051 *$ & $0.11 *$ & $0.16^{* * *}$ & $0.10 * *$ & 0.040 & 0.034 & 0.039 & 0.027 & $0.10^{*}$ \\
\hline & {$[-0.15]$} & {$[-1.77]$} & [1.94] & [3.65] & [2.14] & {$[0.86]$} & {$[0.76]$} & [1.35] & [1.22] & {$[1.74]$} \\
\hline \multicolumn{11}{|l|}{ Livestock } \\
\hline \multirow[t]{2}{*}{ Poultry } & 0.36 & -0.0042 & -0.034 & $0.67 * * *$ & 0.096 & -0.21 & -0.27 & $-0.081 * * *$ & 0.25 & 0.37 \\
\hline & {$[1.34]$} & {$[-1.53]$} & {$[-0.11]$} & [20.2] & {$[0.34]$} & {$[-0.84]$} & [-1.07] & [-4.58] & [0.93] & {$[1.45]$} \\
\hline \multirow{2}{*}{ Farming } & -0.015 & -0.0014 & $0.17 * * *$ & $0.21 * * *$ & $0.11 * * *$ & $-0.091 * * *$ & $-0.090 * * *$ & $0.099 * * *$ & $0.088 * * *$ & $0.14 * * *$ \\
\hline & {$[-0.53]$} & {$[-0.50]$} & {$[4.75]$} & {$[7.39]$} & {$[2.96]$} & {$[-2.79]$} & {$[-2.74]$} & [6.19] & [5.15] & [4.48] \\
\hline \multirow{3}{*}{$\begin{array}{l}\text { Non-earning } \\
\text { occupation }\end{array}$} & & & & & & & & & & \\
\hline & $-0.068 * *$ & -0.0014 & $0.30 * * *$ & $0.31 * * *$ & $0.27 * * *$ & $0.13 * * *$ & $0.12 * * *$ & $0.065 * * *$ & $0.12 * * *$ & 0.0062 \\
\hline & {$[-2.46]$} & {$[-0.50]$} & [12.1] & [12.0] & [11.0] & {$[4.57]$} & [4.68] & [5.20] & [8.73] & {$[0.23]$} \\
\hline \multirow{2}{*}{ Income $(\log )$} & $0.0085 * * *$ & -0.00038 & $0.018 * * *$ & $0.017 * * *$ & $0.018 * * *$ & $0.0080^{*}$ & $0.0083^{*}$ & -0.0030 & $-0.0050 * *$ & $-0.015 * * *$ \\
\hline & [3.24] & {$[-1.53]$} & [5.76] & [5.02] & [6.04] & [1.72] & [1.86] & {$[-1.54]$} & {$[-2.28]$} & {$[-3.80]$} \\
\hline \multirow{2}{*}{ Wealth index } & $-0.029 * * *$ & 0.00020 & 0.0077 & 0.0045 & $0.028 * * *$ & $0.030 * * *$ & $0.029 * * *$ & $-0.029 * * *$ & $-0.032 * * *$ & $-0.043 * * *$ \\
\hline & {$[-7.10]$} & {$[0.74]$} & {$[1.41]$} & {$[1.16]$} & [4.90] & [6.22] & [6.19] & {$[-10.6]$} & {$[-9.11]$} & {$[-10.5]$} \\
\hline \multicolumn{11}{|l|}{ Marital status } \\
\hline \multirow[t]{2}{*}{ Married } & $0.25^{* * *}$ & $0.0023 * * *$ & $-0.31 * * *$ & $-0.30 * * *$ & $-0.42 * * *$ & $-0.15 * * *$ & $-0.12 * * *$ & $0.085 * * *$ & $0.15^{* * *}$ & $0.17 * * *$ \\
\hline & [15.1] & [2.59] & {$[-18.0]$} & {$[-17.1]$} & {$[-17.3]$} & {$[-6.00]$} & {$[-5.45]$} & [10.1] & [11.2] & [12.8] \\
\hline \multirow[t]{2}{*}{ Widow/widower } & $-0.026^{* *}$ & -0.0010 & $-0.21 * * *$ & $-0.22 * * *$ & $-0.20 * * *$ & $0.036^{*}$ & 0.028 & $-0.050 * * *$ & -0.015 & $-0.023^{*}$ \\
\hline & {$[-2.28]$} & {$[-1.00]$} & {$[-10.6]$} & {$[-10.5]$} & {$[-8.25]$} & {$[1.83]$} & {$[1.57]$} & {$[-6.00]$} & {$[-1.54]$} & {$[-1.69]$} \\
\hline \multirow{2}{*}{ Divorced } & -0.0012 & -0.0018 & $-0.097 * *$ & $-0.094 * *$ & $-0.094 * *$ & $0.059^{*}$ & 0.044 & $-0.034 * *$ & 0.022 & -0.029 \\
\hline & {$[-0.060]$} & {$[-1.25]$} & {$[-2.06]$} & {$[-2.01]$} & {$[-2.00]$} & {$[1.67]$} & [1.28] & {$[-2.48]$} & [1.13] & {$[-0.96]$} \\
\hline \multirow{3}{*}{$\begin{array}{l}\text { Separated/ } \\
\text { deserted }\end{array}$} & & & & & & & & & & \\
\hline & $0.041 *$ & $0.022 *$ & $-0.26^{* * *}$ & $-0.25 * * *$ & $-0.23 * * *$ & 0.029 & 0.012 & $-0.049 * * *$ & -0.0019 & -0.0069 \\
\hline & [1.82] & {$[1.83]$} & {$[-6.80]$} & {$[-6.65]$} & {$[-5.74]$} & [0.81] & [0.34] & {$[-5.61]$} & {$[-0.16]$} & {$[-0.24]$} \\
\hline \multirow[t]{2}{*}{ Constant } & $-0.088^{* *}$ & 0.0046 & $0.47 * * *$ & $0.46^{* * *}$ & $0.48 * * *$ & $0.67 * * *$ & $0.68 * * *$ & -0.0098 & $-0.057 * *$ & $0.20 * * *$ \\
\hline & {$[-2.06]$} & {$[1.37]$} & [11.4] & {$[10.0]$} & [11.7] & [11.4] & [12.2] & {$[-0.47]$} & {$[-2.49]$} & {$[3.97]$} \\
\hline Observations & 24,084 & 24,084 & 24,084 & 24,084 & 24,084 & 24,084 & 24,084 & 24,084 & 24,084 & 24,084 \\
\hline R-squared & 0.41 & 0.41 & 0.37 & 0.37 & 0.33 & 0.060 & 0.13 & 0.32 & 0.30 & 0.20 \\
\hline
\end{tabular}

128 Journal of Business Diversity Vol. 21(2) 2021 
TABLE B6

EFFECT OF INTERNATIONAL MIGRATION OF A MEMBER ON WOMEN'S EMPOWERMENT INDICATORS (LPM RESULT)

\begin{tabular}{|c|c|c|c|c|c|c|c|c|c|c|}
\hline VARIABLES & $\begin{array}{l}\text { domestic } \\
\text { violence }\end{array}$ & $\begin{array}{l}\text { emotional } \\
\text { violence }\end{array}$ & no market & $\begin{array}{l}\qquad(4) \\
\text { no } \\
\text { friends/ } \\
\text { relatives }\end{array}$ & no ngo & $\begin{array}{l}\text { production } \\
\text { activity }\end{array}$ & $\begin{array}{l}\text { production } \\
\text { decision }\end{array}$ & $\begin{array}{l}\text { no money } \\
\text { to spend }\end{array}$ & $\begin{array}{l}\text { not earning } \\
\text { money }\end{array}$ & $\begin{array}{l}\quad(10) \\
\text { not } \\
\text { comfortable } \\
\text { to speak in } \\
\text { front of } \\
\text { public }\end{array}$ \\
\hline $\begin{array}{l}\text { International } \\
\text { migration }\end{array}$ & $\begin{array}{c}-0.04 * * * \\
{[-3.61]}\end{array}$ & $\begin{array}{c}-0.0015 \\
{[-1.29]}\end{array}$ & $\begin{array}{c}-0.0048 \\
{[-0.30]}\end{array}$ & $\begin{array}{c}0.0054 \\
{[0.39]}\end{array}$ & $\begin{array}{l}-0.020 \\
{[-1.41]}\end{array}$ & $\begin{array}{c}-0.13 * * * \\
{[-3.38]}\end{array}$ & $\begin{array}{c}-0.13 * * * \\
{[-3.38]}\end{array}$ & $\begin{array}{c}0.0012 \\
{[0.18]}\end{array}$ & $\begin{array}{c}0.057 * * * \\
{[3.43]}\end{array}$ & $\begin{array}{l}0.1 * * * \\
{[3.87]}\end{array}$ \\
\hline Age & $\begin{array}{c}0.017 * * * \\
{[4.05]}\end{array}$ & $\begin{array}{c}0.00044 \\
{[1.16]}\end{array}$ & $\begin{array}{c}0.012 * * \\
{[2.13]}\end{array}$ & $\begin{array}{c}0.0096^{*} \\
{[1.71]}\end{array}$ & $\begin{array}{l}0.0038 \\
{[0.58]}\end{array}$ & $\begin{array}{c}-0.0098 \\
{[-1.55]}\end{array}$ & $\begin{array}{c}-0.0052 \\
{[-0.92]}\end{array}$ & $\begin{array}{c}0.021 * * * \\
{[7.06]}\end{array}$ & $\begin{array}{c}0.018^{* * *} \\
{[5.00]}\end{array}$ & $\begin{array}{c}0.020 * * * \\
{[3.93]}\end{array}$ \\
\hline $\begin{array}{l}\text { Number of } \\
\text { children }\end{array}$ & $\begin{array}{c}0.010 * * * \\
{[4.56]}\end{array}$ & $\begin{array}{c}-0.00015 \\
{[-0.56]}\end{array}$ & $\begin{array}{c}0.015 * * * \\
{[5.37]}\end{array}$ & $\begin{array}{c}0.019 * * * \\
{[7.64]}\end{array}$ & $\begin{array}{c}0.016 * * * \\
{[5.36]}\end{array}$ & $\begin{array}{r}-0.0017 \\
{[-0.49]}\end{array}$ & $\begin{array}{c}-0.0028 \\
{[-0.85]}\end{array}$ & $\begin{array}{c}-0.0047 * * * \\
{[-2.99]}\end{array}$ & $\begin{array}{c}-0.0061 * * * \\
{[-3.25]}\end{array}$ & $\begin{array}{c}-0.0036 \\
{[-1.37]}\end{array}$ \\
\hline $\begin{array}{l}\text { Workplace } \\
\text { (urban) }\end{array}$ & $\begin{array}{c}0.0036 \\
{[0.43]}\end{array}$ & $\begin{array}{c}-0.00011 \\
{[-0.11]}\end{array}$ & $\begin{array}{c}-0.019 * * * \\
{[-2.76]}\end{array}$ & $\begin{array}{c}-0.0054 \\
{[-0.61]}\end{array}$ & $\begin{array}{c}-0.0072 \\
{[-0.84]}\end{array}$ & $\begin{array}{c}-0.0051 \\
{[-0.40]}\end{array}$ & $\begin{array}{l}-0.0015 \\
{[-0.12]}\end{array}$ & $\begin{array}{c}0.0095 \\
{[1.49]}\end{array}$ & $\begin{array}{c}0.020 * * * \\
{[2.76]}\end{array}$ & $\begin{array}{c}0.021 * * \\
{[2.16]}\end{array}$ \\
\hline $\begin{array}{l}\text { total value of } \\
\text { asset bought at } \\
\text { the time of } \\
\text { marriage (log) }\end{array}$ & $\begin{array}{c}0.0066 * * * \\
{[7.75]}\end{array}$ & $\begin{array}{c}0.000038 \\
{[0.46]}\end{array}$ & $\begin{array}{c}0.0014 \\
{[1.34]}\end{array}$ & $\begin{array}{c}0.00037 \\
{[0.37]}\end{array}$ & $\begin{array}{c}0.0032 * * * \\
{[2.95]}\end{array}$ & $\begin{array}{c}0.0073 * * * \\
{[5.96]}\end{array}$ & $\begin{array}{c}0.0072 * * * \\
{[5.77]}\end{array}$ & $\begin{array}{c}-0.0037 * * * \\
{[-5.56]}\end{array}$ & $\begin{array}{c}-0.0022 * * * \\
{[-3.11]}\end{array}$ & $\begin{array}{c}-0.0068 * * * \\
{[-5.90]}\end{array}$ \\
\hline $\begin{array}{l}\text { Level of } \\
\text { education }\end{array}$ & & & & & & & & & & \\
\hline Primary & $\begin{array}{c}-0.0036 \\
{[-0.63]}\end{array}$ & $\begin{array}{c}-0.000078 \\
{[-0.11]}\end{array}$ & $\begin{array}{c}0.024 * * * \\
{[3.85]}\end{array}$ & $\begin{array}{c}0.019 * * * \\
{[3.26]}\end{array}$ & $\begin{array}{c}0.032 * * * \\
{[5.53]}\end{array}$ & $\begin{array}{c}0.031 * * * \\
{[5.26]}\end{array}$ & $\begin{array}{c}0.024 * * * \\
{[3.99]}\end{array}$ & $\begin{array}{c}-0.015^{* * *} \\
{[-3.64]}\end{array}$ & $\begin{array}{c}-0.013 * * \\
{[-2.37]}\end{array}$ & $\begin{array}{c}-0.028 * * * \\
{[-5.16]}\end{array}$ \\
\hline Secondary & $\begin{array}{c}-0.026 * * * \\
{[-2.66]}\end{array}$ & $\begin{array}{c}0.00012 \\
{[0.10]}\end{array}$ & $\begin{array}{c}0.060 * * * \\
{[6.93]}\end{array}$ & $\begin{array}{c}0.056 * * * \\
{[6.43]}\end{array}$ & $\begin{array}{c}0.066 * * * \\
{[6.10]}\end{array}$ & $\begin{array}{c}0.045 * * * \\
{[4.97]}\end{array}$ & $\begin{array}{c}0.035 * * * \\
{[4.15]}\end{array}$ & $\begin{array}{c}-0.032 * * * \\
{[-6.32]}\end{array}$ & $\begin{array}{c}-0.020 * * * \\
{[-2.91]}\end{array}$ & $\begin{array}{c}-0.041 * * * \\
{[-5.96]}\end{array}$ \\
\hline $\mathrm{SSC} / \mathrm{HSC}$ & $\begin{array}{c}-0.062 * * * \\
{[-5.14]}\end{array}$ & $\begin{array}{c}-0.0026^{* *} \\
{[-2.52]}\end{array}$ & $\begin{array}{c}0.080 * * * \\
{[6.83]}\end{array}$ & $\begin{array}{c}0.083 * * * \\
{[6.49]}\end{array}$ & $\begin{array}{c}0.10^{* * *} * \\
{[6.58]}\end{array}$ & $\begin{array}{c}0.055^{*} * * \\
{[5.17]}\end{array}$ & $\begin{array}{c}0.046^{* * *} * \\
{[4.53]}\end{array}$ & $\begin{array}{c}-0.044 * * * \\
{[-8.74]}\end{array}$ & $\begin{array}{c}-0.034 * * * \\
{[-4.40]}\end{array}$ & $\begin{array}{c}-0.073 * * * \\
{[-7.49]}\end{array}$ \\
\hline Graduate & $-0.12 * * *$ & $-0.0035^{*}$ & $0.13 * * *$ & $0.15^{* * *}$ & $0.16^{* * *}$ & $0.10 * * *$ & $0.087 * * *$ & -0.028 & $-0.054 * * *$ & $-0.086 * * *$ \\
\hline & {$[-4.01]$} & {$[-1.84]$} & [3.79] & [3.99] & [3.97] & [3.51] & [3.04] & {$[-1.40]$} & {$[-2.82]$} & {$[-3.51]$} \\
\hline
\end{tabular}




\begin{tabular}{|c|c|c|c|c|c|c|c|c|c|c|}
\hline \multicolumn{11}{|l|}{ Occupation } \\
\hline \multirow[t]{2}{*}{ Salaried worker } & 0.018 & 0.0020 & 0.055 & 0.053 & 0.058 & $0.057 *$ & 0.032 & 0.000047 & 0.021 & -0.031 \\
\hline & {$[0.59]$} & {$[0.39]$} & {$[1.31]$} & {$[1.27]$} & {$[1.51]$} & [1.77] & [0.97] & {$[0.0042]$} & {$[1.40]$} & {$[-1.06]$} \\
\hline \multirow[t]{2}{*}{ Self employed } & -0.037 & 0.0054 & 0.040 & $0.069 *$ & 0.061 & $0.088 * *$ & $0.090 * * *$ & 0.026 & 0.019 & $0.056^{*}$ \\
\hline & {$[-1.03]$} & {$[0.82]$} & {$[1.01]$} & {$[1.84]$} & {$[1.57]$} & {$[2.43]$} & {$[2.62]$} & {$[1.52]$} & {$[1.20]$} & {$[1.70]$} \\
\hline \multirow[t]{2}{*}{ Trader } & -0.025 & 0.014 & 0.036 & 0.027 & 0.068 & 0.031 & -0.0052 & 0.0038 & -0.0029 & -0.025 \\
\hline & {$[-0.49]$} & {$[0.70]$} & {$[0.59]$} & {$[0.43]$} & [1.14] & {$[0.62]$} & {$[-0.10]$} & {$[0.17]$} & {$[-0.12]$} & {$[-0.52]$} \\
\hline \multirow[t]{2}{*}{ Production food } & -0.0053 & $-0.0051 *$ & $0.11 *$ & $0.16^{* * *}$ & $0.10 * *$ & 0.045 & 0.038 & 0.039 & 0.026 & $0.10^{*}$ \\
\hline & {$[-0.12]$} & {$[-1.75]$} & {$[1.95]$} & {$[3.66]$} & {$[2.16]$} & {$[0.96]$} & {$[0.86]$} & {$[1.35]$} & [1.17] & {$[1.65]$} \\
\hline \multicolumn{11}{|l|}{ Livestock } \\
\hline \multirow[t]{2}{*}{ Poultry } & 0.35 & -0.0044 & -0.036 & $0.67 * * *$ & 0.093 & -0.24 & -0.30 & $-0.080 * * *$ & 0.25 & 0.39 \\
\hline & {$[1.34]$} & {$[-1.64]$} & {$[-0.12]$} & [20.1] & {$[0.33]$} & {$[-0.91]$} & [-1.13] & {$[-4.78]$} & [0.94] & [1.47] \\
\hline \multirow[t]{2}{*}{ Farming } & -0.015 & -0.0013 & $0.17 * * *$ & $0.21 * * *$ & $0.11 * * *$ & $-0.090 * * *$ & $-0.089 * * *$ & $0.099 * * *$ & $0.088 * * *$ & $0.14 * * *$ \\
\hline & {$[-0.53]$} & {$[-0.50]$} & {$[4.76]$} & [7.39] & {$[2.96]$} & {$[-2.75]$} & {$[-2.71]$} & [6.17] & {$[5.16]$} & {$[4.45]$} \\
\hline \multicolumn{11}{|l|}{ Non-earning } \\
\hline occupation & $\begin{array}{c}-0.068 * * \\
{[-2.44]}\end{array}$ & $\begin{array}{c}-0.0014 \\
{[-0.49]}\end{array}$ & $\begin{array}{c}0.30 * * * \\
{[12.2]}\end{array}$ & $\begin{array}{c}0.31 * * * \\
{[12.0]}\end{array}$ & $\begin{array}{c}0.27 * * * \\
{[11.0]}\end{array}$ & $\begin{array}{c}0.13 * * * \\
{[4.77]}\end{array}$ & $\begin{array}{c}0.12 * * * \\
{[4.92]}\end{array}$ & $\begin{array}{c}0.065^{* * *} * \\
{[5.20]}\end{array}$ & $\begin{array}{c}0.12 * * * \\
{[8.80]}\end{array}$ & $\begin{array}{c}0.0036 \\
{[0.13]}\end{array}$ \\
\hline \multirow[t]{2}{*}{ Income $(\log )$} & $0.0083 * * *$ & -0.00037 & $0.018 * * *$ & $0.017 * * *$ & $0.018 * * *$ & $0.0079^{*}$ & $0.0083^{*}$ & -0.0031 & $-0.0039^{*}$ & $-0.015 * * *$ \\
\hline & [3.32] & {$[-1.48]$} & [5.84] & [5.12] & [5.87] & [1.67] & [1.82] & [-1.64] & [-1.83] & {$[-3.87]$} \\
\hline \multirow[t]{2}{*}{ Wealth index } & $-0.028 * * *$ & 0.00023 & 0.0076 & 0.0044 & $0.029 * * *$ & $0.033 * * *$ & $0.032 * * *$ & $-0.029 * * *$ & $-0.033 * * *$ & $-0.045 * * *$ \\
\hline & [-6.78] & {$[0.84]$} & {$[1.40]$} & [1.11] & {$[5.03]$} & [6.34] & {$[6.26]$} & [-10.6] & {$[-9.80]$} & [-10.9] \\
\hline \multicolumn{11}{|l|}{ Marital status } \\
\hline Married & $\begin{array}{c}0.25 * * * \\
{[15.1]}\end{array}$ & $\begin{array}{c}0.0023 * * * \\
{[2.59]}\end{array}$ & $\begin{array}{c}-0.31 * * * \\
{[-18.0]}\end{array}$ & $\begin{array}{c}-0.30 * * * \\
{[-17.0]}\end{array}$ & $\begin{array}{c}-0.42 * * * \\
{[-17.3]}\end{array}$ & $\begin{array}{c}-0.15 * * * \\
{[-5.93]}\end{array}$ & $\begin{array}{c}-0.12 * * * \\
{[-5.40]}\end{array}$ & $\begin{array}{c}0.085 * * * \\
{[10.1]}\end{array}$ & $\begin{array}{c}0.15 * * * \\
{[11.2]}\end{array}$ & $\begin{array}{c}0.16 * * * \\
{[12.9]}\end{array}$ \\
\hline \multirow[t]{2}{*}{ Widow/ widower } & $-0.027 * *$ & -0.0010 & $-0.21 * * *$ & $-0.22 * * *$ & $-0.20 * * *$ & $0.034^{*}$ & 0.027 & $-0.050 * * *$ & -0.014 & -0.023 \\
\hline & {$[-2.31]$} & {$[-1.01]$} & {$[-10.6]$} & {$[-10.4]$} & {$[-8.25]$} & {$[1.82]$} & {$[1.56]$} & {$[-6.00]$} & {$[-1.41]$} & {$[-1.64]$} \\
\hline \multirow[t]{2}{*}{ Divorced } & -0.0012 & -0.0018 & $-0.097 * *$ & $-0.094 * *$ & $-0.094 * *$ & $0.061 *$ & 0.045 & $-0.034 * *$ & 0.023 & -0.030 \\
\hline & {$[-0.056]$} & {$[-1.24]$} & {$[-2.05]$} & {$[-2.00]$} & [-1.99] & [1.72] & [1.32] & {$[-2.48]$} & [1.16] & {$[-0.98]$} \\
\hline \multirow[t]{2}{*}{$\begin{array}{l}\text { Separated/ } \\
\text { deserted }\end{array}$} & $0.042 *$ & $0.022 *$ & $-0.26 * * *$ & $-0.25 * * *$ & $-0.23 * * *$ & 0.034 & & $-0.050 * * *$ & -0.0022 & -0.011 \\
\hline & {$[1.86]$} & {$[1.84]$} & {$[-6.79]$} & {$[-6.65]$} & {$[-5.72]$} & [0.98] & [0.49] & {$[-5.67]$} & {$[-0.18]$} & {$[-0.38]$} \\
\hline \multirow[t]{2}{*}{ Constant } & $-0.088 * *$ & 0.0045 & $0.46 * * *$ & $0.46 * * *$ & $0.48 * * *$ & $0.66 * * *$ & $0.67 * * *$ & -0.0080 & $-0.068 * * *$ & $0.21 * * *$ \\
\hline & {$[-2.14]$} & [1.32] & [11.3] & [10.2] & [11.6] & [11.5] & [12.3] & {$[-0.38]$} & [-2.94] & [4.14] \\
\hline Observations & 24,084 & 24,084 & 24,084 & 24,084 & 24,084 & 24,084 & 24,084 & 24,084 & 24,084 & 24,084 \\
\hline R-squared & 0.41 & 0.41 & 0.37 & 0.37 & 0.33 & 0.057 & 0.13 & 0.32 & 0.30 & 0.20 \\
\hline
\end{tabular}

Note: Robust t-statistics are in brackets, ***, ** and * denote 1, 5 and 10 percent level of significance, respectively. All regressions include other controls, and woman fixed effects. Also, standard errors are clustered at district level. 
TABLE B7

EFFECT OF MIGRATION OF A MEMBER ON WOMEN'S EMPOWERMENT INDICATORS (IV RESULT)

\begin{tabular}{|c|c|c|c|c|c|c|c|c|c|c|}
\hline VARIABLES & $\begin{array}{l}\text { domestic } \\
\text { violence }\end{array}$ & $\begin{array}{l}\text { emotional } \\
\text { violence }\end{array}$ & no market & $\begin{array}{l}\quad(4) \\
\text { no } \\
\text { friends/ } \\
\text { relatives }\end{array}$ & no ngo & $\begin{array}{l}\text { production } \\
\text { activity }\end{array}$ & $\begin{array}{l}\text { production } \\
\text { decision }\end{array}$ & $\begin{array}{l}\text { no money } \\
\text { to spend }\end{array}$ & $\begin{array}{l}\text { not earning } \\
\text { money }\end{array}$ & $\begin{array}{l}\quad(10) \\
\text { not } \\
\text { comfortable to } \\
\text { speak in front } \\
\text { of public }\end{array}$ \\
\hline Migration & $\begin{array}{c}0.0099 \\
{[0.71]}\end{array}$ & $\begin{array}{c}-0.00052 \\
{[-0.46]}\end{array}$ & $\begin{array}{l}-0.024 \\
{[-1.48]}\end{array}$ & $\begin{array}{c}-0.0095 \\
{[-0.66]}\end{array}$ & $\begin{array}{c}-0.038 * \\
{[-1.71]}\end{array}$ & $\begin{array}{c}-0.15 * * * \\
{[-4.77]}\end{array}$ & $\begin{array}{c}-0.14 * * * \\
{[-4.88]}\end{array}$ & $\begin{array}{c}0.016 * \\
{[1.95]}\end{array}$ & $\begin{array}{c}0.023 * * \\
{[2.21]}\end{array}$ & $\begin{array}{c}0.10 * * * \\
{[4.99]}\end{array}$ \\
\hline Age & $\begin{array}{c}0.12 * * * \\
{[18.1]}\end{array}$ & $\begin{array}{c}0.00043 \\
{[0.47]}\end{array}$ & $\begin{array}{c}-0.12 * * * \\
{[-11.8]}\end{array}$ & $\begin{array}{c}-0.10 * * * \\
{[-12.5]}\end{array}$ & $\begin{array}{c}-0.17 * * * \\
{[-15.6]}\end{array}$ & $\begin{array}{c}-0.11 * * * \\
{[-9.43]}\end{array}$ & $\begin{array}{c}-0.092 * * * \\
{[-8.32]}\end{array}$ & $\begin{array}{c}0.067 * * * \\
{[16.6]}\end{array}$ & $\begin{array}{c}0.085 * * * \\
{[12.5]}\end{array}$ & $\begin{array}{c}0.12 * * * \\
{[14.7]}\end{array}$ \\
\hline $\begin{array}{l}\text { Number of } \\
\text { children }\end{array}$ & $\begin{array}{c}0.0028 \\
{[0.48]}\end{array}$ & $\begin{array}{l}-7.8 \mathrm{e}-06 \\
{[-0.014]}\end{array}$ & $\begin{array}{c}0.020 * * * \\
{[3.93]}\end{array}$ & $\begin{array}{c}0.029 * * * \\
{[4.11]}\end{array}$ & $\begin{array}{c}0.032 * * * \\
{[5.95]}\end{array}$ & $\begin{array}{c}-0.0047 \\
{[-0.49]}\end{array}$ & $\begin{array}{c}-0.0060 \\
{[-0.67]}\end{array}$ & $\begin{array}{c}-0.013 * * * \\
{[-2.77]}\end{array}$ & $\begin{array}{c}-0.016 * * * \\
{[-3.57]}\end{array}$ & $\begin{array}{c}-0.0024 \\
{[-0.36]}\end{array}$ \\
\hline $\begin{array}{l}\text { Workplace } \\
\text { (urban) } \\
\text { total value of } \\
\text { asset bought } \\
\text { at the time of } \\
\text { marriage }\end{array}$ & $\begin{array}{c}0.0063 * * * \\
{[4.86]}\end{array}$ & $\begin{array}{c}-0.00076 \\
{[-0.39]}\end{array}$ & $\begin{array}{c}0.00041 \\
{[0.25]}\end{array}$ & $\begin{array}{c}-0.0024 \\
{[-1.37]}\end{array}$ & $\begin{array}{c}0.0043 * * * \\
{[2.58]}\end{array}$ & $\begin{array}{c}0.062 * * * \\
{[2.79]}\end{array}$ & $\begin{array}{c}0.061 * * * \\
{[2.93]}\end{array}$ & $\begin{array}{c}-0.0073 * * * \\
{[-6.27]}\end{array}$ & $\begin{array}{c}-0.0073 * * * \\
{[-6.10]}\end{array}$ & $\begin{array}{c}-0.014 * * * \\
{[-7.09]}\end{array}$ \\
\hline $\begin{array}{l}\text { Level of } \\
\text { education }\end{array}$ & $\begin{array}{c}-0.0089 * * \\
{[-2.30]}\end{array}$ & $\begin{array}{c}0.000068 \\
{[0.11]}\end{array}$ & $\begin{array}{c}0.036 * * * \\
{[9.23]}\end{array}$ & $\begin{array}{c}0.038 * * * \\
{[9.16]}\end{array}$ & $\begin{array}{c}0.043 * * * \\
{[7.85]}\end{array}$ & $\begin{array}{c}0.036 * * * \\
{[9.36]}\end{array}$ & $\begin{array}{c}0.032 * * * \\
{[8.24]}\end{array}$ & $\begin{array}{c}-0.016 * * * \\
{[-7.88]}\end{array}$ & $\begin{array}{c}-0.012 * * * \\
{[-4.29]}\end{array}$ & $\begin{array}{c}-0.030 * * * \\
{[-9.37]}\end{array}$ \\
\hline Occupation & $\begin{array}{c}-0.021 * * * \\
{[-4.54]}\end{array}$ & $\begin{array}{c}-0.00074^{*} \\
{[-1.72]}\end{array}$ & $\begin{array}{c}0.053 * * * \\
{[15.7]}\end{array}$ & $\begin{array}{c}0.051 * * * \\
{[12.6]}\end{array}$ & $\begin{array}{c}0.056^{* * * *} \\
{[12.8]}\end{array}$ & $\begin{array}{c}0.035 * * * \\
{[8.15]}\end{array}$ & $\begin{array}{c}0.032 * * * \\
{[8.83]}\end{array}$ & $\begin{array}{c}-0.00084 \\
{[-0.44]}\end{array}$ & $\begin{array}{c}0.0088 * * * \\
{[3.86]}\end{array}$ & $\begin{array}{c}-0.018 * * * \\
{[-4.20]}\end{array}$ \\
\hline Income (log) & $\begin{array}{l}0.010^{*} \\
{[1.75]}\end{array}$ & $\begin{array}{c}-0.00035 \\
{[-0.81]}\end{array}$ & $\begin{array}{c}0.0043 \\
{[0.73]}\end{array}$ & $\begin{array}{c}0.00011 \\
{[0.016]}\end{array}$ & $\begin{array}{c}0.0068 \\
{[0.98]}\end{array}$ & $\begin{array}{c}0.050 * * * \\
{[4.40]}\end{array}$ & $\begin{array}{c}0.044 * * * \\
{[4.27]}\end{array}$ & $\begin{array}{c}-0.019 * * * \\
{[-4.02]}\end{array}$ & $\begin{array}{c}-0.014 * * * \\
{[-3.09]}\end{array}$ & $\begin{array}{c}-0.041 * * * \\
{[-4.55]}\end{array}$ \\
\hline Wealth index & $\begin{array}{l}0.019 \\
{[1.42]}\end{array}$ & $\begin{array}{c}0.00049 \\
{[0.49]}\end{array}$ & $\begin{array}{l}-0.014 \\
{[-0.93]}\end{array}$ & $\begin{array}{c}-0.063 * * * \\
{[-4.71]}\end{array}$ & $\begin{array}{c}0.054 * * * \\
{[3.07]}\end{array}$ & $\begin{array}{c}0.27 * * * \\
{[13.8]}\end{array}$ & $\begin{array}{c}0.24 * * * \\
{[13.8]}\end{array}$ & $\begin{array}{c}-0.092 * * * \\
{[-11.6]}\end{array}$ & $\begin{array}{c}-0.12 * * * \\
{[-11.5]}\end{array}$ & $\begin{array}{c}-0.21 * * * \\
{[-13.9]}\end{array}$ \\
\hline Marital status & $\begin{array}{c}-0.027 * * * \\
{[-4.53]}\end{array}$ & $\begin{array}{l}0.0011 \\
{[0.71]}\end{array}$ & $\begin{array}{c}-0.032 * * * \\
{[-2.90]}\end{array}$ & $\begin{array}{c}-0.041 * * * \\
{[-3.83]}\end{array}$ & $\begin{array}{c}-0.022^{*} \\
{[-1.81]}\end{array}$ & $\begin{array}{c}0.039 * * * \\
{[4.30]}\end{array}$ & $\begin{array}{c}0.030 * * * \\
{[3.64]}\end{array}$ & $\begin{array}{c}-0.032 * * * \\
{[-9.23]}\end{array}$ & $\begin{array}{c}-0.028 * * * \\
{[-6.23]}\end{array}$ & $\begin{array}{c}-0.039 * * * \\
{[-5.83]}\end{array}$ \\
\hline Observations & 23,423 & 23,423 & 23,423 & 23,423 & 23,423 & 23,423 & 23,423 & 23,423 & 23,423 & 23,423 \\
\hline
\end{tabular}




\begin{tabular}{|c|c|c|c|c|c|c|c|c|c|c|}
\hline R-squared & 0.12 & 0.00 & 0.18 & 0.17 & 0.24 & 0.16 & 0.14 & 0.07 & 0.09 & 0.15 \\
\hline \multirow{2}{*}{$\begin{array}{l}\text { First stage F- } \\
\text { stat } \\
\text { Hansen p- } \\
\text { value }\end{array}$} & 684 & 684 & 684 & 684 & 684 & 684 & 684 & 684 & 684 & 684 \\
\hline & 0.58 & 0.85 & 0.65 & 0.14 & 0.22 & 0.15 & 0.16 & 0.88 & 0.43 & 0.42 \\
\hline
\end{tabular}

TABLE B8

EFFECT OF INTERNAL MIGRATION OF A MEMBER ON WOMEN'S EMPOWERMENT INDICATORS (IV RESULT)

\begin{tabular}{|c|c|c|c|c|c|c|c|c|c|c|}
\hline VARIABLES & $\begin{array}{l}\text { domestic } \\
\text { violence }\end{array}$ & $\begin{array}{l}\text { emotional } \\
\text { violence }\end{array}$ & no market & $\begin{array}{l}\text { no } \\
\text { friends/ } \\
\text { relatives }\end{array}$ & no ngo & $\begin{array}{l}\text { production } \\
\text { activity }\end{array}$ & $\begin{array}{l}\text { production } \\
\text { decision }\end{array}$ & $\begin{array}{l}\text { no money } \\
\text { to spend }\end{array}$ & $\begin{array}{l}\text { not earning } \\
\text { money }\end{array}$ & $\begin{array}{l}\quad(10) \\
\text { not } \\
\text { comfortable } \\
\text { to speak in } \\
\text { front of } \\
\text { public }\end{array}$ \\
\hline Internal migration & $\begin{array}{c}0.014 \\
{[0.74]}\end{array}$ & $\begin{array}{c}-0.00070 \\
{[-0.45]}\end{array}$ & $\begin{array}{l}-0.032 \\
{[-1.45]}\end{array}$ & $\begin{array}{l}-0.011 \\
{[-0.59]}\end{array}$ & $\begin{array}{c}-0.050 * \\
{[-1.72]}\end{array}$ & $\begin{array}{c}-0.20 * * * \\
{[-4.91]}\end{array}$ & $\begin{array}{c}-0.19 * * * \\
{[-5.01]}\end{array}$ & $\begin{array}{c}0.022 * * \\
{[1.97]}\end{array}$ & $\begin{array}{c}0.031 * * \\
{[2.18]}\end{array}$ & $\begin{array}{c}0.14^{* * *} \\
{[4.93]}\end{array}$ \\
\hline Age & $\begin{array}{c}0.12 * * * \\
{[18.1]}\end{array}$ & $\begin{array}{c}0.00043 \\
{[0.47]}\end{array}$ & $\begin{array}{c}-0.12 * * * \\
{[-11.8]}\end{array}$ & $\begin{array}{c}-0.10 * * * \\
{[-12.5]}\end{array}$ & $\begin{array}{c}-0.17 * * * \\
{[-15.6]}\end{array}$ & $\begin{array}{c}-0.11 * * * \\
{[-9.39]}\end{array}$ & $\begin{array}{c}-0.092 * * * \\
{[-8.29]}\end{array}$ & $\begin{array}{c}0.067 * * * \\
{[16.6]}\end{array}$ & $\begin{array}{c}0.085 * * * \\
{[12.5]}\end{array}$ & $\begin{array}{c}0.12 * * * \\
{[14.6]}\end{array}$ \\
\hline $\begin{array}{l}\text { Number of } \\
\text { children }\end{array}$ & $\begin{array}{c}0.0028 \\
{[0.47]}\end{array}$ & $\begin{array}{c}-3.7 e-06 \\
{[-0.0065]}\end{array}$ & $\begin{array}{c}0.020 * * * \\
{[4.00]}\end{array}$ & $\begin{array}{c}0.029 * * * \\
{[4.13]}\end{array}$ & $\begin{array}{c}0.033 * * * \\
{[6.15]}\end{array}$ & $\begin{array}{c}-0.0036 \\
{[-0.39]}\end{array}$ & $\begin{array}{c}-0.0049 \\
{[-0.57]}\end{array}$ & $\begin{array}{c}-0.013 * * * \\
{[-2.81]}\end{array}$ & $\begin{array}{c}-0.016 * * * \\
{[-3.63]}\end{array}$ & $\begin{array}{c}-0.0032 \\
{[-0.48]}\end{array}$ \\
\hline $\begin{array}{l}\text { Workplace } \\
\text { (urban) } \\
\text { total value of } \\
\text { asset bought at } \\
\text { the time of } \\
\text { marriage }\end{array}$ & $\begin{array}{c}0.0063 * * * \\
{[4.85]}\end{array}$ & $\begin{array}{c}-0.00076 \\
{[-0.39]}\end{array}$ & $\begin{array}{c}0.00048 \\
{[0.29]}\end{array}$ & $\begin{array}{c}-0.0023 \\
{[-1.36]}\end{array}$ & $\begin{array}{c}0.0044 * * * \\
{[2.65]}\end{array}$ & $\begin{array}{c}0.061 * * * \\
{[2.70]}\end{array}$ & $\begin{array}{c}0.060 * * * \\
{[2.83]}\end{array}$ & $\begin{array}{c}-0.0073 * * * \\
{[-6.35]}\end{array}$ & $\begin{array}{c}-0.0074 * * * \\
{[-6.18]}\end{array}$ & $\begin{array}{c}-0.015 * * * \\
{[-7.22]}\end{array}$ \\
\hline
\end{tabular}

132 Journal of Business Diversity Vol. 21(2) 2021 


\begin{tabular}{|c|c|c|c|c|c|c|c|c|c|c|}
\hline $\begin{array}{l}\text { Level of } \\
\text { education }\end{array}$ & $\begin{array}{c}-0.0089 * * \\
{[-2.30]}\end{array}$ & $\begin{array}{c}0.000067 \\
{[0.11]}\end{array}$ & $\begin{array}{c}0.036^{* * *} \\
{[9.21]}\end{array}$ & $\begin{array}{c}0.038^{* * *} \\
{[9.16]}\end{array}$ & $\begin{array}{c}0.043 * * * \\
{[7.84]}\end{array}$ & $\begin{array}{c}0.036^{* * *} \\
{[9.27]}\end{array}$ & $\begin{array}{c}0.032 * * * \\
{[8.16]}\end{array}$ & $\begin{array}{c}-0.016^{* * *} \\
{[-7.86]}\end{array}$ & $\begin{array}{c}-0.012 * * * \\
{[-4.28]}\end{array}$ & $\begin{array}{c}-0.029 * * * \\
{[-9.35]}\end{array}$ \\
\hline Occupation & $\begin{array}{c}-0.021^{* * *} \\
{[-4.54]}\end{array}$ & $\begin{array}{c}-0.00074 * \\
{[-1.72]}\end{array}$ & $\begin{array}{c}0.053 * * * \\
{[15.7]}\end{array}$ & $\begin{array}{c}0.051 * * * \\
{[12.6]}\end{array}$ & $\begin{array}{c}0.056^{* * *} \\
{[12.8]}\end{array}$ & $\begin{array}{c}0.035^{* * *} \\
{[8.16]}\end{array}$ & $\begin{array}{c}0.032 * * * \\
{[8.83]}\end{array}$ & $\begin{array}{c}-0.00083 \\
{[-0.43]}\end{array}$ & $\begin{array}{c}0.0088^{* * *} \\
{[3.86]}\end{array}$ & $\begin{array}{c}-0.018^{* * *} \\
{[-4.18]}\end{array}$ \\
\hline Income $(\log )$ & $\begin{array}{l}0.010^{*} \\
{[1.76]}\end{array}$ & $\begin{array}{c}-0.00035 \\
{[-0.82]}\end{array}$ & $\begin{array}{l}0.0042 \\
{[0.72]}\end{array}$ & $\begin{array}{l}0.00012 \\
{[0.017]}\end{array}$ & $\begin{array}{l}0.0067 \\
{[0.96]}\end{array}$ & $\begin{array}{c}0.049 * * * \\
{[4.29]}\end{array}$ & $\begin{array}{c}0.043 * * * \\
{[4.15]}\end{array}$ & $\begin{array}{c}-0.019 * * * \\
{[-4.01]}\end{array}$ & $\begin{array}{c}-0.014 * * * \\
{[-3.05]}\end{array}$ & $\begin{array}{c}-0.040 * * * \\
{[-4.48]}\end{array}$ \\
\hline Wealth index & $\begin{array}{l}0.019 \\
{[1.42]}\end{array}$ & $\begin{array}{c}0.00049 \\
{[0.49]}\end{array}$ & $\begin{array}{l}-0.014 \\
{[-0.92]}\end{array}$ & $\begin{array}{c}-0.063 * * * \\
{[-4.70]}\end{array}$ & $\begin{array}{c}0.054 * * * \\
{[3.08]}\end{array}$ & $\begin{array}{c}0.27 * * * \\
{[13.8]}\end{array}$ & $\begin{array}{c}0.24 * * * \\
{[13.7]}\end{array}$ & $\begin{array}{c}-0.092 * * * \\
{[-11.5]}\end{array}$ & $\begin{array}{c}-0.12 * * * \\
{[-11.5]}\end{array}$ & $\begin{array}{c}-0.21 * * * \\
{[-13.7]}\end{array}$ \\
\hline Marital status & $\begin{array}{c}-0.027 * * * \\
{[-4.52]}\end{array}$ & $\begin{array}{l}0.0011 \\
{[0.71]}\end{array}$ & $\begin{array}{c}-0.032 * * * \\
{[-2.90]}\end{array}$ & $\begin{array}{c}-0.041 * * * \\
{[-3.83]}\end{array}$ & $\begin{array}{l}-0.022^{*} \\
{[-1.81]}\end{array}$ & $\begin{array}{c}0.039^{* * *} \\
{[4.26]}\end{array}$ & $\begin{array}{c}0.030^{* * *} \\
{[3.59]}\end{array}$ & $\begin{array}{c}-0.032 * * * \\
{[-9.21]}\end{array}$ & $\begin{array}{c}-0.028^{* * *} \\
{[-6.22]}\end{array}$ & $\begin{array}{c}-0.039 * * * \\
{[-5.79]}\end{array}$ \\
\hline Observations & 23,423 & 23,423 & 23,423 & 23,423 & 23,423 & 23,423 & 23,423 & 23,423 & 23,423 & 23,423 \\
\hline R-squared & 0.12 & 0.00 & 0.18 & 0.17 & 0.24 & 0.16 & 0.14 & 0.07 & 0.09 & 0.15 \\
\hline $\begin{array}{l}\text { First stage F-stat } \\
\text { Hansen p-value }\end{array}$ & $\begin{array}{l}356 \\
0.60\end{array}$ & $\begin{array}{l}356 \\
0.83\end{array}$ & $\begin{array}{l}356 \\
0.61\end{array}$ & $\begin{array}{l}356 \\
0.14\end{array}$ & $\begin{array}{l}356 \\
0.20\end{array}$ & $\begin{array}{l}356 \\
0.14\end{array}$ & $\begin{array}{l}356 \\
0.19\end{array}$ & $\begin{array}{l}356 \\
0.82\end{array}$ & $\begin{array}{l}356 \\
0.38\end{array}$ & $\begin{array}{l}356 \\
0.29\end{array}$ \\
\hline
\end{tabular}

Note: Robust $t$-statistics are in brackets, $* * *, * *$ and $*$ denote 1,5 and 10 percent level of significance, respectively. All regressions include other controls, and woman fixed effects. Also, standard errors are clustered at district level. 
TABLE B9

EFFECT OF INTERNATIONAL MIGRATION OF A MEMBER ON WOMEN'S EMPOWERMENT INDICATORS (IV RESULT)

\begin{tabular}{|c|c|c|c|c|c|c|c|c|c|c|}
\hline VARIABLES & $\begin{array}{l}\text { domestic } \\
\text { violence }\end{array}$ & $\begin{array}{l}\text { emotional } \\
\text { violence }\end{array}$ & no market & $\begin{array}{l}\text { no } \\
\text { friends/ } \\
\text { relatives }\end{array}$ & no ngo & $\begin{array}{l}\text { production } \\
\text { activity }\end{array}$ & $\begin{array}{l}\text { production } \\
\text { decision }\end{array}$ & $\begin{array}{l}\text { no money } \\
\text { to spend }\end{array}$ & $\begin{array}{l}\text { not earning } \\
\text { money }\end{array}$ & $\begin{array}{l}\quad(10) \\
\text { not } \\
\text { comfortable to } \\
\text { speak in front } \\
\text { of public }\end{array}$ \\
\hline $\begin{array}{l}\text { International } \\
\text { migration }\end{array}$ & $\begin{array}{l}0.032 \\
{[0.63]}\end{array}$ & $\begin{array}{c}-0.0019 \\
{[-0.47]}\end{array}$ & $\begin{array}{l}-0.087 \\
{[-1.49]}\end{array}$ & $\begin{array}{l}-0.043 \\
{[-0.83]}\end{array}$ & $\begin{array}{c}-0.14 \\
{[-1.62]}\end{array}$ & $\begin{array}{c}-0.53 * * * \\
{[-3.91]}\end{array}$ & $\begin{array}{c}-0.50 * * * \\
{[-4.01]}\end{array}$ & $\begin{array}{c}0.057^{*} \\
{[1.79]}\end{array}$ & $\begin{array}{c}0.084 * * \\
{[2.20]}\end{array}$ & $\begin{array}{c}0.37 * * * \\
{[4.42]}\end{array}$ \\
\hline Age & $\begin{array}{c}0.12 * * * \\
{[18.1]}\end{array}$ & $\begin{array}{c}0.00043 \\
{[0.47]}\end{array}$ & $\begin{array}{c}-0.12 * * * \\
{[-11.8]}\end{array}$ & $\begin{array}{c}-0.10 * * * \\
{[-12.5]}\end{array}$ & $\begin{array}{c}-0.17 * * * \\
{[-15.6]}\end{array}$ & $\begin{array}{c}-0.11 * * * \\
{[-9.56]}\end{array}$ & $\begin{array}{c}-0.092 * * * \\
{[-8.41]}\end{array}$ & $\begin{array}{c}0.067 * * * \\
{[16.6]}\end{array}$ & $\begin{array}{c}0.085 * * * \\
{[12.5]}\end{array}$ & $\begin{array}{c}0.12 * * * \\
{[14.6]}\end{array}$ \\
\hline $\begin{array}{l}\text { Number of } \\
\text { children }\end{array}$ & $\begin{array}{c}0.0029 \\
{[0.49]}\end{array}$ & $\begin{array}{c}-0.000015 \\
{[-0.027]}\end{array}$ & $\begin{array}{c}0.019 * * * \\
{[3.75]}\end{array}$ & $\begin{array}{c}0.028 * * * \\
{[4.05]}\end{array}$ & $\begin{array}{c}0.032 * * * \\
{[5.42]}\end{array}$ & $\begin{array}{c}-0.0069 \\
{[-0.62]}\end{array}$ & $\begin{array}{c}-0.0080 \\
{[-0.78]}\end{array}$ & $\begin{array}{c}-0.012 * * * \\
{[-2.67]}\end{array}$ & $\begin{array}{c}-0.015 * * * \\
{[-3.44]}\end{array}$ & $\begin{array}{c}-0.00099 \\
{[-0.14]}\end{array}$ \\
\hline $\begin{array}{l}\text { Workplace } \\
\text { (urban) }\end{array}$ & $\begin{array}{l}-0.023 \\
{[-1.58]}\end{array}$ & $\begin{array}{c}-0.00075 \\
{[-0.39]}\end{array}$ & $\begin{array}{l}0.027 \\
{[1.59]}\end{array}$ & $\begin{array}{l}0.023 \\
{[1.43]}\end{array}$ & $\begin{array}{c}0.075 * * * \\
{[4.75]}\end{array}$ & $\begin{array}{c}0.063 * * * \\
{[2.93]}\end{array}$ & $\begin{array}{c}0.062 * * * \\
{[3.07]}\end{array}$ & $\begin{array}{c}-0.021 * \\
{[-1.89]}\end{array}$ & $\begin{array}{l}-0.0057 \\
{[-0.44]}\end{array}$ & $\begin{array}{c}-0.048 * * \\
{[-2.37]}\end{array}$ \\
\hline $\begin{array}{l}\text { total value of } \\
\text { asset bought at } \\
\text { the time of } \\
\text { marriage }\end{array}$ & $\begin{array}{c}0.0064 * * * \\
{[4.85]}\end{array}$ & $\begin{array}{c}0.00010 \\
{[0.65]}\end{array}$ & $\begin{array}{c}0.00021 \\
{[0.13]}\end{array}$ & $\begin{array}{l}-0.0025 \\
{[-1.41]}\end{array}$ & $\begin{array}{c}0.0039 * * \\
{[2.32]}\end{array}$ & $\begin{array}{c}0.017 * * * \\
{[6.99]}\end{array}$ & $\begin{array}{c}0.015 * * * \\
{[6.50]}\end{array}$ & $\begin{array}{c}-0.0071 * * * \\
{[-6.08]}\end{array}$ & $\begin{array}{c}-0.0071 * * * \\
{[-5.82]}\end{array}$ & $\begin{array}{c}-0.013 * * * \\
{[-6.53]}\end{array}$ \\
\hline $\begin{array}{l}\text { Level of } \\
\text { education }\end{array}$ & $\begin{array}{c}-0.0089 * * \\
{[-2.30]}\end{array}$ & $\begin{array}{c}0.000068 \\
{[0.11]}\end{array}$ & $\begin{array}{c}0.036 * * * \\
{[9.25]}\end{array}$ & $\begin{array}{c}0.038 * * * \\
{[9.16]}\end{array}$ & $\begin{array}{c}0.043 * * * \\
{[7.89]}\end{array}$ & $\begin{array}{c}0.037 * * * \\
{[9.46]}\end{array}$ & $\begin{array}{c}0.032 * * * \\
{[8.31]}\end{array}$ & $\begin{array}{c}-0.016^{* * *} \\
{[-7.90]}\end{array}$ & $\begin{array}{c}-0.012 * * * \\
{[-4.29]}\end{array}$ & $\begin{array}{c}-0.030 * * * \\
{[-9.31]}\end{array}$ \\
\hline Occupation & $\begin{array}{c}-0.021 * * * \\
{[-4.55]}\end{array}$ & $\begin{array}{c}-0.00074 * \\
{[-1.72]}\end{array}$ & $\begin{array}{c}0.053 * * * \\
{[15.7]}\end{array}$ & $\begin{array}{c}0.051 * * * \\
{[12.6]}\end{array}$ & $\begin{array}{c}0.056 * * * \\
{[12.8]}\end{array}$ & $\begin{array}{c}0.035 * * * \\
{[8.14]}\end{array}$ & $\begin{array}{c}0.032 * * * \\
{[8.86]}\end{array}$ & $\begin{array}{c}-0.00084 \\
{[-0.44]}\end{array}$ & $\begin{array}{c}0.0088 * * * \\
{[3.87]}\end{array}$ & $\begin{array}{c}-0.018 * * * \\
{[-4.21]}\end{array}$ \\
\hline Income (log) & $\begin{array}{c}0.010^{*} \\
{[1.74]} \\
\end{array}$ & $\begin{array}{c}-0.00035 \\
{[-0.81]} \\
\end{array}$ & $\begin{array}{c}0.0044 \\
{[0.74]} \\
\end{array}$ & $\begin{array}{c}0.000052 \\
{[0.0077]}\end{array}$ & $\begin{array}{c}0.0069 \\
{[0.99]} \\
\end{array}$ & $\begin{array}{c}0.050 * * * \\
{[4.44]}\end{array}$ & $\begin{array}{c}0.045 * * * \\
{[4.31]}\end{array}$ & $\begin{array}{c}-0.019 * * * \\
{[-3.99]}\end{array}$ & $\begin{array}{c}-0.015 * * * \\
{[-3.13]}\end{array}$ & $\begin{array}{c}-0.041 * * * \\
{[-4.56]}\end{array}$ \\
\hline
\end{tabular}

134 Journal of Business Diversity Vol. 21(2) 2021 


\begin{tabular}{|c|c|c|c|c|c|c|c|c|c|c|}
\hline Wealth index & $\begin{array}{l}0.019 \\
{[1.43]}\end{array}$ & $\begin{array}{c}0.00048 \\
{[0.48]}\end{array}$ & $\begin{array}{l}-0.014 \\
{[-0.95]}\end{array}$ & $\begin{array}{c}-0.063 * * * \\
{[-4.74]}\end{array}$ & $\begin{array}{c}0.053 * * * \\
{[3.05]}\end{array}$ & $\begin{array}{c}0.27 * * * \\
{[13.7]}\end{array}$ & $\begin{array}{c}0.24 * * * \\
{[13.7]}\end{array}$ & $\begin{array}{c}-0.091 * * * \\
{[-11.6]}\end{array}$ & $\begin{array}{c}-0.12 * * * \\
{[-11.6]}\end{array}$ & $\begin{array}{c}-0.21 * * * \\
{[-14.0]}\end{array}$ \\
\hline Marital status & $\begin{array}{c}-0.027 * * * \\
{[-4.53]}\end{array}$ & $\begin{array}{l}0.0011 \\
{[0.71]}\end{array}$ & $\begin{array}{c}-0.032 * * * \\
{[-2.90]}\end{array}$ & $\begin{array}{c}-0.041 * * * \\
{[-3.83]}\end{array}$ & $\begin{array}{c}-0.022 * \\
{[-1.82]}\end{array}$ & $\begin{array}{c}0.040 * * * \\
{[4.39]}\end{array}$ & $\begin{array}{c}0.030 * * * \\
{[3.70]}\end{array}$ & $\begin{array}{c}-0.032 * * * \\
{[-9.28]}\end{array}$ & $\begin{array}{c}-0.028 * * * \\
{[-6.26]}\end{array}$ & $\begin{array}{c}-0.039 * * * \\
{[-5.85]}\end{array}$ \\
\hline Observations & 23,423 & 23,423 & 23,423 & 23,423 & 23,423 & 23,423 & 23,423 & 23,423 & 23,423 & 23,423 \\
\hline R-squared & 0.12 & 0.00 & 0.18 & 0.17 & 0.24 & 0.14 & 0.13 & 0.07 & 0.09 & 0.14 \\
\hline $\begin{array}{l}\text { First stage F- } \\
\text { stat } \\
\text { Hansen p-value }\end{array}$ & $\begin{array}{c}32 \\
0.52 \\
\end{array}$ & $\begin{array}{c}32 \\
0.91 \\
\end{array}$ & $\begin{array}{c}32 \\
0.76 \\
\end{array}$ & $\begin{array}{c}32 \\
0.15 \\
\end{array}$ & $\begin{array}{c}32 \\
0.28 \\
\end{array}$ & $\begin{array}{c}32 \\
0.58 \\
\end{array}$ & $\begin{array}{c}32 \\
0.60 \\
\end{array}$ & $\begin{array}{c}32 \\
0.96 \\
\end{array}$ & $\begin{array}{c}32 \\
0.61 \\
\end{array}$ & $\begin{array}{c}32 \\
0.92 \\
\end{array}$ \\
\hline
\end{tabular}

woman fixed effects. Also, standard errors are clustered at district level.

\section{EFFECT OF ABSENCE OF A MEMBER ON INDICATORS OF WOMEN'S EMPOWERMENT (LPM RESULT)}

\begin{tabular}{|c|c|c|c|c|c|c|c|c|c|c|}
\hline VARIABLES & $\begin{array}{l}\text { Physical } \\
\text { Violence }\end{array}$ & $\begin{array}{l}\text { Emotional } \\
\text { Violence }\end{array}$ & $\begin{array}{l}\text { Unable to } \\
\text { go to } \\
\text { market }\end{array}$ & $\begin{array}{l}\quad \text { (4) } \\
\text { Unable to } \\
\text { visit } \\
\text { relatives } \\
\text { or friends }\end{array}$ & $\begin{array}{l}\text { Unable to } \\
\text { receive } \\
\text { training }\end{array}$ & $\begin{array}{l}\quad(6) \\
\text { Does not } \\
\text { participate } \\
\text { in } \\
\text { production }\end{array}$ & \begin{tabular}{l}
\multicolumn{1}{c}{$(7)$} \\
Does not \\
participate \\
in decision- \\
making \\
regarding \\
production
\end{tabular} & $\begin{array}{l}\text { Does not } \\
\text { have } \\
\text { money to } \\
\text { spend }\end{array}$ & $\begin{array}{l}\text { Does not } \\
\text { earn } \\
\text { money }\end{array}$ & $\begin{array}{l}\quad \quad(10) \\
\text { Does not } \\
\text { feel } \\
\text { comfortable } \\
\text { speaking in } \\
\text { public }\end{array}$ \\
\hline $\begin{array}{l}\text { Absence of a } \\
\text { member }\end{array}$ & $\begin{array}{c}-0.058 * * * \\
{[-3.35]}\end{array}$ & $\begin{array}{c}0.0024 \\
{[0.71]}\end{array}$ & $\begin{array}{c}-0.34 * * * \\
{[-18.2]}\end{array}$ & $\begin{array}{c}-0.32 * * * \\
{[-16.5]}\end{array}$ & $\begin{array}{c}-0.30 * * * \\
{[-12.2]}\end{array}$ & $\begin{array}{c}0.11 * * * \\
{[9.46]}\end{array}$ & $\begin{array}{c}0.10 * * * \\
{[8.74]}\end{array}$ & $\begin{array}{c}-0.012 * * \\
{[-2.33]}\end{array}$ & $\begin{array}{l}-0.010 \\
{[-1.58]}\end{array}$ & $\begin{array}{c}-0.10 * * * \\
{[-10.7]}\end{array}$ \\
\hline Age & $\begin{array}{c}0.0056^{* * * *} \\
{[6.82]}\end{array}$ & $\begin{array}{c}0.00013 * * \\
{[1.97]}\end{array}$ & $\begin{array}{c}-0.012 * * * \\
{[-13.0]}\end{array}$ & $\begin{array}{c}-0.014 * * * \\
{[-14.8]}\end{array}$ & $\begin{array}{c}-0.015 * * * \\
{[-12.5]}\end{array}$ & $\begin{array}{c}-0.0070 * * * \\
{[-10.1]}\end{array}$ & $\begin{array}{c}-0.0062^{* * *} \\
{[-9.39]}\end{array}$ & $\begin{array}{c}0.0034 * * * \\
{[7.54]}\end{array}$ & $\begin{array}{c}0.0045 * * * \\
{[7.51]}\end{array}$ & $\begin{array}{c}0.0068 * * * \\
{[9.43]}\end{array}$ \\
\hline Number of children & $\begin{array}{c}0.023 * * * \\
{[7.07]}\end{array}$ & $\begin{array}{c}0.00025 \\
{[0.76]}\end{array}$ & $\begin{array}{c}-0.012 * * * \\
{[-2.90]}\end{array}$ & $\begin{array}{c}-0.0086^{* *} \\
{[-2.44]}\end{array}$ & $\begin{array}{c}-0.016^{* * *} \\
{[-3.65]}\end{array}$ & $\begin{array}{c}-0.014 * * * \\
{[-3.95]}\end{array}$ & $\begin{array}{c}-0.015 * * * \\
{[-4.28]}\end{array}$ & $\begin{array}{r}-0.0023 \\
{[-1.51]}\end{array}$ & $\begin{array}{c}0.0024 \\
{[1.07]}\end{array}$ & $\begin{array}{c}0.0088 * * * \\
{[2.70]}\end{array}$ \\
\hline $\begin{array}{l}\text { Workplace (rural/ } \\
\text { urban) }\end{array}$ & $\begin{array}{l}0.0097 \\
{[1.17]}\end{array}$ & $\begin{array}{l}-5.9 \mathrm{e}-06 \\
{[-0.0060]}\end{array}$ & $\begin{array}{c}-0.025 * * * \\
{[-3.84]}\end{array}$ & $\begin{array}{l}-0.015^{*} \\
{[-1.93]}\end{array}$ & $\begin{array}{l}-0.010 \\
{[-1.33]}\end{array}$ & $\begin{array}{l}0.0086 \\
{[0.64]}\end{array}$ & $\begin{array}{l}0.011 \\
{[0.82]}\end{array}$ & $\begin{array}{r}0.0049 \\
{[0.94]}\end{array}$ & $\begin{array}{c}0.015^{* * *} * \\
{[3.19]}\end{array}$ & $\begin{array}{l}0.012 \\
{[1.50]}\end{array}$ \\
\hline
\end{tabular}




\begin{tabular}{|c|c|c|c|c|c|c|c|c|c|c|}
\hline $\begin{array}{l}\text { total value of asset } \\
\text { bought at the time } \\
\text { of marriage }\end{array}$ & $\begin{array}{c}0.0053 * * * \\
{[7.74]}\end{array}$ & $\begin{array}{c}0.000035 \\
{[0.40]}\end{array}$ & $\begin{array}{l}0.0011 \\
{[1.11]}\end{array}$ & $\begin{array}{c}0.0016^{*} \\
{[1.90]}\end{array}$ & $\begin{array}{c}0.00088 \\
{[0.96]}\end{array}$ & $\begin{array}{c}0.00013 \\
{[0.15]}\end{array}$ & $\begin{array}{c}0.00045 \\
{[0.49]}\end{array}$ & $\begin{array}{c}-0.00063 \\
{[-1.22]}\end{array}$ & $\begin{array}{c}0.0014 * * \\
{[2.00]}\end{array}$ & $\begin{array}{c}-0.00075 \\
{[-0.85]}\end{array}$ \\
\hline \multicolumn{11}{|l|}{ Level of education } \\
\hline Primary & $\begin{array}{c}-0.025 * * * \\
{[-3.53]}\end{array}$ & $\begin{array}{c}-0.00038 \\
{[-0.52]}\end{array}$ & $\begin{array}{c}0.052 * * * \\
{[6.96]}\end{array}$ & $\begin{array}{c}0.051 * * * \\
{[7.51]}\end{array}$ & $\begin{array}{c}0.061 * * * \\
{[8.27]}\end{array}$ & $\begin{array}{c}0.026^{* * * *} \\
{[4.41]}\end{array}$ & $\begin{array}{c}0.019 * * * \\
{[3.18]}\end{array}$ & $\begin{array}{c}-0.013 * * * \\
{[-2.80]}\end{array}$ & $\begin{array}{c}-0.014 * * \\
{[-2.34]}\end{array}$ & $\begin{array}{c}-0.027 * * * \\
{[-4.31]}\end{array}$ \\
\hline Secondary & $\begin{array}{c}-0.049 * * * \\
{[-4.57]}\end{array}$ & $\begin{array}{c}-0.000079 \\
{[-0.068]}\end{array}$ & $\begin{array}{c}0.096 * * * \\
{[9.53]}\end{array}$ & $\begin{array}{c}0.092 * * * \\
{[9.77]}\end{array}$ & $\begin{array}{c}0.10 * * * \\
{[8.83]}\end{array}$ & $\begin{array}{c}0.045 * * * \\
{[4.96]}\end{array}$ & $\begin{array}{c}0.034 * * * \\
{[4.08]}\end{array}$ & $\begin{array}{c}-0.026 * * * \\
{[-4.60]}\end{array}$ & $\begin{array}{c}-0.020 * * * \\
{[-2.72]}\end{array}$ & $\begin{array}{c}-0.040 * * * \\
{[-5.78]}\end{array}$ \\
\hline $\mathrm{SSC} / \mathrm{HSC}$ & $\begin{array}{c}-0.087 * * * \\
{[-6.43]}\end{array}$ & $\begin{array}{c}-0.0027 * * * \\
{[-2.66]}\end{array}$ & $\begin{array}{c}0.13^{* * * *} \\
{[10.8]}\end{array}$ & $\begin{array}{c}0.13 * * * \\
{[10.6]}\end{array}$ & $\begin{array}{c}0.15^{* * *} * \\
{[9.86]}\end{array}$ & $\begin{array}{c}0.058 * * * \\
{[5.67]}\end{array}$ & $\begin{array}{c}0.049 * * * \\
{[4.94]}\end{array}$ & $\begin{array}{c}-0.036 * * * \\
{[-6.42]}\end{array}$ & $\begin{array}{c}-0.033 * * * \\
{[-4.02]}\end{array}$ & $\begin{array}{c}-0.073 * * * \\
{[-6.97]}\end{array}$ \\
\hline Graduate & $\begin{array}{c}-0.14 * * * \\
{[-4.85]}\end{array}$ & $\begin{array}{c}-0.0036^{* *} \\
{[-2.01]}\end{array}$ & $\begin{array}{c}0.16^{* * *} \\
{[4.43]}\end{array}$ & $\begin{array}{c}0.18 * * * \\
{[4.65]}\end{array}$ & $\begin{array}{c}0.19 * * * \\
{[4.60]}\end{array}$ & $\begin{array}{c}0.097 * * * \\
{[3.92]}\end{array}$ & $\begin{array}{c}0.080 * * * \\
{[3.35]}\end{array}$ & $\begin{array}{l}-0.017 \\
{[-0.81]}\end{array}$ & $\begin{array}{c}-0.048 * * \\
{[-2.31]}\end{array}$ & $\begin{array}{c}-0.079 * * * \\
{[-3.05]}\end{array}$ \\
\hline \multicolumn{11}{|l|}{ Occupation } \\
\hline Salaried worker & $\begin{array}{l}0.023 \\
{[0.72]}\end{array}$ & $\begin{array}{c}0.0021 \\
{[0.41]}\end{array}$ & $\begin{array}{c}0.040 \\
{[1.04]}\end{array}$ & $\begin{array}{c}0.035 \\
{[0.89]}\end{array}$ & $\begin{array}{c}0.046 \\
{[1.28]}\end{array}$ & $\begin{array}{c}0.068 * * * \\
{[2.67]}\end{array}$ & $\begin{array}{c}0.042 \\
{[1.60]}\end{array}$ & $\begin{array}{c}-0.0033 \\
{[-0.31]}\end{array}$ & $\begin{array}{c}0.016 \\
{[1.33]}\end{array}$ & $\begin{array}{l}-0.040 \\
{[-1.44]}\end{array}$ \\
\hline Self employed & $\begin{array}{l}-0.021 \\
{[-0.58]}\end{array}$ & $\begin{array}{l}0.0056 \\
{[0.86]}\end{array}$ & $\begin{array}{l}0.022 \\
{[0.59]}\end{array}$ & $\begin{array}{l}0.047 \\
{[1.39]}\end{array}$ & $\begin{array}{l}0.042 \\
{[1.19]}\end{array}$ & $\begin{array}{c}0.099 * * * \\
{[3.66]}\end{array}$ & $\begin{array}{c}0.10 * * * \\
{[3.81]}\end{array}$ & $\begin{array}{l}0.026 * \\
{[1.65]}\end{array}$ & $\begin{array}{c}0.019 \\
{[1.20]}\end{array}$ & $\begin{array}{l}0.051 \\
{[1.61]}\end{array}$ \\
\hline Trader & -0.021 & 0.014 & 0.017 & 0.0094 & 0.050 & 0.034 & -0.0042 & 0.0035 & -0.0031 & -0.027 \\
\hline Production food & $\begin{array}{l}{[-0.40]} \\
0.0027 \\
{[0.061]}\end{array}$ & $\begin{array}{c}{[0.71]} \\
-0.0048 * \\
{[-1.65]}\end{array}$ & $\begin{array}{l}{[0.29]} \\
0.092 * \\
{[1.67]}\end{array}$ & $\begin{array}{c}{[0.16]} \\
0.14 * * * \\
{[3.96]}\end{array}$ & $\begin{array}{c}{[0.90]} \\
0.085^{*} \\
{[1.96]}\end{array}$ & $\begin{array}{c}{[0.86]} \\
0.063 * * \\
{[1.97]}\end{array}$ & $\begin{array}{l}{[-0.10]} \\
0.054^{*} \\
{[1.73]}\end{array}$ & $\begin{array}{c}{[0.17]} \\
0.036 \\
{[1.37]}\end{array}$ & $\begin{array}{c}{[-0.13]} \\
0.022 \\
{[1.06]}\end{array}$ & $\begin{array}{l}{[-0.60]} \\
0.087^{*} \\
{[1.83]}\end{array}$ \\
\hline Livestock Poultry & $\begin{array}{c}0.38 \\
{[1.42]}\end{array}$ & $\begin{array}{l}-0.0037 \\
{[-1.32]}\end{array}$ & $\begin{array}{l}-0.099 \\
{[-0.31]}\end{array}$ & $\begin{array}{c}0.57 * * * \\
{[11.9]}\end{array}$ & $\begin{array}{c}0.072 \\
{[0.24]}\end{array}$ & $\begin{array}{c}-0.025 \\
{[-0.089]}\end{array}$ & $\begin{array}{c}-0.10 \\
{[-0.36]}\end{array}$ & $\begin{array}{c}-0.14 * * * \\
{[-7.93]}\end{array}$ & $\begin{array}{c}0.17 \\
{[0.64]}\end{array}$ & $\begin{array}{c}0.23 \\
{[0.91]}\end{array}$ \\
\hline Farming & $\begin{array}{l}0.0085 \\
{[0.31]}\end{array}$ & $\begin{array}{c}-0.00092 \\
{[-0.33]}\end{array}$ & $\begin{array}{c}0.12 * * * \\
{[4.18]}\end{array}$ & $\begin{array}{c}0.16 * * * \\
{[6.34]}\end{array}$ & $\begin{array}{c}0.080 * * * \\
{[2.64]}\end{array}$ & $\begin{array}{l}-0.020 \\
{[-1.03]}\end{array}$ & $\begin{array}{l}-0.024 \\
{[-1.19]}\end{array}$ & $\begin{array}{c}0.077 * * * \\
{[5.97]}\end{array}$ & $\begin{array}{c}0.063 * * * \\
{[4.76]}\end{array}$ & $\begin{array}{c}0.082 * * * \\
{[3.41]}\end{array}$ \\
\hline $\begin{array}{l}\text { Non-earning } \\
\text { occupation }\end{array}$ & $\begin{array}{l}-0.042 \\
{[-1.47]}\end{array}$ & $\begin{array}{c}-0.00066 \\
{[-0.23]}\end{array}$ & $\begin{array}{c}0.22 * * * \\
{[9.98]}\end{array}$ & $\begin{array}{c}0.23 * * * \\
{[9.79]}\end{array}$ & $\begin{array}{c}0.19 * * * \\
{[8.27]}\end{array}$ & $\begin{array}{c}0.13 * * * \\
{[6.66]}\end{array}$ & $\begin{array}{c}0.12 * * * \\
{[6.78]}\end{array}$ & $\begin{array}{c}0.067 * * * \\
{[6.66]}\end{array}$ & $\begin{array}{c}0.13 * * * \\
{[10.2]}\end{array}$ & $\begin{array}{c}0.0081 \\
{[0.35]}\end{array}$ \\
\hline Income $(\log )$ & $0.0090 * * *$ & -0.00023 & $0.0083 * * *$ & $0.011 * * *$ & 0.0038 & -0.0057 & -0.0043 & $0.0033^{*}$ & $0.0044 * *$ & -0.0031 \\
\hline Wealth index & $\begin{array}{c}{[3.67]} \\
-0.027 * * *\end{array}$ & $\begin{array}{c}{[-0.94]} \\
0.00031\end{array}$ & $\begin{array}{c}{[2.73]} \\
-0.0023\end{array}$ & $\begin{array}{l}{[4.12]} \\
0.0041\end{array}$ & $\begin{array}{l}{[1.48]} \\
0.0071\end{array}$ & $\begin{array}{c}{[-1.52]} \\
-0.0067\end{array}$ & $\begin{array}{c}{[-1.12]} \\
-0.0060\end{array}$ & $\begin{array}{c}{[1.70]} \\
-0.016^{* * *}\end{array}$ & $\begin{array}{c}{[1.98]} \\
-0.011 * * *\end{array}$ & $\begin{array}{c}{[-1.11]} \\
-0.010 * *\end{array}$ \\
\hline & {$[-7.71]$} & [1.09] & {$[-0.49]$} & [1.11] & {$[1.50]$} & {$[-1.39]$} & {$[-1.25]$} & {$[-6.82]$} & [-3.89] & {$[-2.46]$} \\
\hline Marital Status & & & & & & & & & & \\
\hline Married & $\begin{array}{c}0.23 * * * \\
{[16.6]}\end{array}$ & $\begin{array}{l}0.0015 \\
{[1.54]}\end{array}$ & $\begin{array}{c}-0.16^{* * *} \\
{[-11.3]}\end{array}$ & $\begin{array}{c}-0.13 * * * \\
{[-9.21]}\end{array}$ & $\begin{array}{c}-0.26 * * * \\
{[-14.6]}\end{array}$ & $\begin{array}{c}-0.13 * * * \\
{[-6.39]}\end{array}$ & $\begin{array}{c}-0.097 * * * \\
{[-5.61]}\end{array}$ & $\begin{array}{c}0.085 * * * \\
{[12.0]}\end{array}$ & $\begin{array}{c}0.15 * * * \\
{[15.5]}\end{array}$ & $\begin{array}{c}0.15 * * * \\
{[12.9]}\end{array}$ \\
\hline Widow/widower & $\begin{array}{c}0.015 \\
{[0.91]} \\
\end{array}$ & $\begin{array}{c}-0.0015 \\
{[-0.74]}\end{array}$ & $\begin{array}{c}-0.051 * * * \\
{[-2.74]}\end{array}$ & $\begin{array}{l}-0.028 \\
{[-1.41]}\end{array}$ & $\begin{array}{c}-0.061 * * * \\
{[-2.70]}\end{array}$ & $\begin{array}{c}0.00028 \\
{[0.020]}\end{array}$ & $\begin{array}{l}0.0040 \\
{[0.30]} \\
\end{array}$ & $\begin{array}{c}-0.031 * * * \\
{[-3.20]}\end{array}$ & $\begin{array}{c}0.014 \\
{[1.28]} \\
\end{array}$ & $\begin{array}{c}0.019 \\
{[1.20]}\end{array}$ \\
\hline
\end{tabular}

136 Journal of Business Diversity Vol. 21(2) 2021 


\begin{tabular}{|c|c|c|c|c|c|c|c|c|c|c|}
\hline Divorced & $\begin{array}{l}-0.019 \\
{[-0.92]}\end{array}$ & $\begin{array}{c}-0.0025 \\
{[-1.56]}\end{array}$ & $\begin{array}{c}0.054 \\
{[1.42]}\end{array}$ & $\begin{array}{c}0.083 * * \\
{[2.34]}\end{array}$ & $\begin{array}{c}0.054 \\
{[1.39]}\end{array}$ & $\begin{array}{c}0.049 * \\
{[1.73]}\end{array}$ & $\begin{array}{c}0.040 \\
{[1.41]}\end{array}$ & $\begin{array}{c}-0.024 * \\
{[-1.68]}\end{array}$ & $\begin{array}{c}0.031 \\
{[1.53]}\end{array}$ & $\begin{array}{l}-0.018 \\
{[-0.63]}\end{array}$ \\
\hline Separated/ deserted & $\begin{array}{c}0.030 \\
{[1.33]}\end{array}$ & $\begin{array}{c}0.021 * \\
{[1.73]}\end{array}$ & $\begin{array}{c}-0.073 * * \\
{[-2.23]}\end{array}$ & $\begin{array}{l}-0.042 \\
{[-1.29]}\end{array}$ & $\begin{array}{l}-0.053 \\
{[-1.53]}\end{array}$ & $\begin{array}{c}0.016 \\
{[0.60]}\end{array}$ & $\begin{array}{c}0.0060 \\
{[0.23]}\end{array}$ & $\begin{array}{c}-0.040 * * * \\
{[-4.91]}\end{array}$ & $\begin{array}{c}0.0063 \\
{[0.56]}\end{array}$ & $\begin{array}{c}0.0079 \\
{[0.35]}\end{array}$ \\
\hline Constant & $\begin{array}{c}-0.099 * * \\
{[-2.34]}\end{array}$ & $\begin{array}{l}0.0033 \\
{[0.93]}\end{array}$ & $\begin{array}{c}0.65 * * * \\
{[19.0]}\end{array}$ & $\begin{array}{c}0.65 * * * \\
{[16.6]}\end{array}$ & $\begin{array}{c}0.66 * * * \\
{[18.0]}\end{array}$ & $\begin{array}{c}0.61 * * * \\
{[14.2]}\end{array}$ & $\begin{array}{c}0.63 * * * \\
{[14.7]}\end{array}$ & $\begin{array}{c}-0.0080 \\
{[-0.45]}\end{array}$ & $\begin{array}{c}-0.063 * * * \\
{[-2.97]}\end{array}$ & $\begin{array}{c}0.24 * * * \\
{[7.10]}\end{array}$ \\
\hline $\begin{array}{l}\text { Observations } \\
\text { Number of clusters } \\
\text { R-squared }\end{array}$ & $\begin{array}{c}24,084 \\
64 \\
0.19\end{array}$ & $\begin{array}{c}24,084 \\
64 \\
0.01\end{array}$ & $\begin{array}{c}24,084 \\
64 \\
0.26\end{array}$ & $\begin{array}{c}24,084 \\
64 \\
0.26\end{array}$ & $\begin{array}{c}24,084 \\
64 \\
0.35\end{array}$ & $\begin{array}{c}24,084 \\
64 \\
0.41\end{array}$ & $\begin{array}{c}24,084 \\
64 \\
0.35\end{array}$ & $\begin{array}{c}24,084 \\
64 \\
0.15\end{array}$ & $\begin{array}{c}24,084 \\
64 \\
0.20\end{array}$ & $\begin{array}{c}24,084 \\
64 \\
0.33\end{array}$ \\
\hline
\end{tabular}

Note: Robust t-statistics are in brackets, ***, ** and * denote 1, 5 and 10 percent level of significance, respectively. All regressions include other controls, and woman fixed effects. Also, standard errors are clustered at district level.

TABLE B11

EFFECT OF ABSENCE OF A MEMBER ON WOMEN'S EMPOWERMENT INDEX (LPM RESULT)

\begin{tabular}{|c|c|c|c|c|}
\hline VARIABLES & $\begin{array}{c}(1) \\
\text { AFM }\end{array}$ & $\begin{array}{c}(2) \\
\text { PCA }\end{array}$ & $\begin{array}{l}\text { (3) } \\
\text { FA }\end{array}$ & $\begin{array}{c}\text { (4) } \\
\text { MCA }\end{array}$ \\
\hline Absence of a member & $\begin{array}{c}-0.069 * * * \\
{[-13.8]}\end{array}$ & $\begin{array}{c}-0.36^{* * *} \\
{[-8.40]}\end{array}$ & $\begin{array}{c}-0.36 * * * \\
{[-8.40]}\end{array}$ & $\begin{array}{l}-0.058^{*} \\
{[-1.68]}\end{array}$ \\
\hline Age & $\begin{array}{c}-0.0012 * * * \\
{[-4.30]}\end{array}$ & $\begin{array}{c}-0.044 * * * \\
{[-17.7]}\end{array}$ & $\begin{array}{c}-0.044 * * * \\
{[-17.7]}\end{array}$ & $\begin{array}{c}-0.037 * * * \\
{[-17.0]}\end{array}$ \\
\hline Number of children & $\begin{array}{r}-0.0015 \\
{[-1.57]}\end{array}$ & $\begin{array}{c}-0.062 * * * \\
{[-5.35]}\end{array}$ & $\begin{array}{c}-0.062 * * * \\
{[-5.35]}\end{array}$ & $\begin{array}{c}-0.059 * * * \\
{[-5.06]}\end{array}$ \\
\hline Workplace (rural/urban) & $\begin{array}{l}0.0034 \\
{[1.14]}\end{array}$ & $\begin{array}{c}-0.050^{* *} \\
{[-2.18]}\end{array}$ & $\begin{array}{c}-0.050^{* *} \\
{[-2.18]}\end{array}$ & $\begin{array}{l}-0.037 \\
{[-1.33]}\end{array}$ \\
\hline $\begin{array}{l}\text { total value of asset bought at the time } \\
\text { of marriage }\end{array}$ & $\begin{array}{l}0.00071 * * \\
{[2.53]}\end{array}$ & $\begin{array}{c}-0.00015 \\
{[-0.074]}\end{array}$ & $\begin{array}{l}-0.00015 \\
{[-0.074]}\end{array}$ & $\begin{array}{l}-0.00013 \\
{[-0.063]}\end{array}$ \\
\hline Level of education & & & & \\
\hline Primary & $\begin{array}{c}0.0046^{*} \\
{[1.77]}\end{array}$ & $\begin{array}{c}0.17 * * * \\
{[9.99]}\end{array}$ & $\begin{array}{c}0.17 * * * \\
{[9.99]}\end{array}$ & $\begin{array}{c}0.13 * * * \\
{[9.38]}\end{array}$ \\
\hline Secondary & $\begin{array}{c}0.010 * * * \\
{[3.11]}\end{array}$ & $\begin{array}{c}0.29 * * * \\
{[12.2]}\end{array}$ & $\begin{array}{c}0.29 * * * \\
{[12.2]}\end{array}$ & $\begin{array}{c}0.23 * * * \\
{[11.5]}\end{array}$ \\
\hline $\mathrm{SSC} / \mathrm{HSC}$ & $\begin{array}{c}0.0082 * * \\
{[2.24]}\end{array}$ & $\begin{array}{c}0.43^{* * * *} \\
{[12.8]}\end{array}$ & $\begin{array}{c}0.43 * * * \\
{[12.8]}\end{array}$ & $\begin{array}{c}0.34 * * * \\
{[11.6]}\end{array}$ \\
\hline Graduate & 0.016 & $0.55 * * *$ & $0.55 * * *$ & $0.45 * * *$ \\
\hline
\end{tabular}




\begin{tabular}{|c|c|c|c|c|}
\hline & {$[1.35]$} & {$[6.43]$} & {$[6.43]$} & {$[5.86]$} \\
\hline \multicolumn{5}{|l|}{ Occupation } \\
\hline \multirow[t]{2}{*}{ Salaried worker } & 0.016 & 0.12 & 0.12 & $0.15^{* *}$ \\
\hline & {$[1.52]$} & [1.49] & [1.49] & {$[2.21]$} \\
\hline \multirow[t]{2}{*}{ Self employed } & $0.041 * * *$ & 0.11 & 0.11 & $0.12 * *$ \\
\hline & {$[3.72]$} & {$[1.44]$} & {$[1.44]$} & {$[2.07]$} \\
\hline \multirow[t]{2}{*}{ Trader } & 0.0055 & 0.045 & 0.045 & 0.067 \\
\hline & {$[0.31]$} & {$[0.38]$} & {$[0.38]$} & {$[0.66]$} \\
\hline \multirow[t]{2}{*}{ Production food } & $0.058 * * *$ & 0.17 & 0.17 & 0.12 \\
\hline & [4.82] & [1.61] & [1.61] & {$[1.25]$} \\
\hline \multirow[t]{2}{*}{ Livestock Poultry } & 0.11 & -0.12 & -0.12 & -0.34 \\
\hline & [0.94] & {$[-0.14]$} & {$[-0.14]$} & {$[-0.66]$} \\
\hline \multirow[t]{2}{*}{ Farming } & $0.052 * * *$ & 0.033 & 0.033 & -0.044 \\
\hline & [6.83] & {$[0.51]$} & {$[0.51]$} & {$[-0.78]$} \\
\hline \multirow[t]{2}{*}{ Non-earning occupation } & $0.085 * * *$ & $0.38 * * *$ & $0.38 * * *$ & $0.29 * * *$ \\
\hline & {$[13.3]$} & {$[8.02]$} & {$[8.02]$} & {$[6.15]$} \\
\hline \multirow[t]{2}{*}{ Income (log) } & $0.0016^{*}$ & 0.00025 & 0.00025 & -0.0088 \\
\hline & [1.66] & {$[0.032]$} & {$[0.032]$} & {$[-1.06]$} \\
\hline \multirow[t]{2}{*}{ Wealth index } & $-0.0084 * * *$ & $0.037 * * *$ & $0.037 * * *$ & $0.023 *$ \\
\hline & {$[-6.11]$} & [3.46] & [3.46] & [1.93] \\
\hline \multicolumn{5}{|l|}{ Marital status } \\
\hline \multirow{2}{*}{ Married } & $0.017 * * *$ & $-0.83 * * *$ & $-0.83 * * *$ & $-0.75 * * *$ \\
\hline & [3.98] & {$[-21.6]$} & {$[-21.6]$} & {$[-19.2]$} \\
\hline \multirow[t]{2}{*}{ Widow/widower } & -0.0077 & $-0.11 * *$ & $-0.11 * *$ & $-0.091 * *$ \\
\hline & {$[-1.56]$} & {$[-2.14]$} & {$[-2.14]$} & {$[-2.10]$} \\
\hline \multirow[t]{2}{*}{ Divorced } & 0.016 & $0.16^{*}$ & $0.16^{*}$ & 0.12 \\
\hline & {$[1.47]$} & {$[1.75]$} & {$[1.75]$} & {$[1.46]$} \\
\hline \multirow[t]{2}{*}{ Separated/deserted } & -0.0072 & -0.11 & -0.11 & -0.063 \\
\hline & {$[-0.85]$} & {$[-1.16]$} & {$[-1.16]$} & {$[-0.82]$} \\
\hline \multirow[t]{2}{*}{ Constant } & $0.28 * * *$ & $-0.55 * * *$ & $-0.55 * * *$ & $-0.55 * * *$ \\
\hline & [28.7] & {$[-5.86]$} & {$[-5.86]$} & {$[-5.46]$} \\
\hline Observations & 24,084 & 24,084 & 24,084 & 24,084 \\
\hline R-squared & 0.1 & 0.52 & 0.52 & 0.55 \\
\hline
\end{tabular}

138 Journal of Business Diversity Vol. 21(2) 2021 
TABLE B12

EFFECT OF MIGRATION OF A MEMBER ON WOMEN'S EMPOWERMENT INDEX IN DIFFERENT CUT-OFF POINTS (LPM RESULTS)

\begin{tabular}{|c|c|c|c|c|c|c|}
\hline \multirow[b]{2}{*}{ VARIABLES } & (1) & $(2)$ & (3) & (4) & $(5)$ & $(6)$ \\
\hline & \multicolumn{3}{|c|}{ Deprivation at least one dimension } & \multicolumn{3}{|c|}{ Deprivation at least three dimensions } \\
\hline \multirow{3}{*}{ Migration } & Overall & Internal & International & Overall & Internal & International \\
\hline & $-0.14 * * *$ & $-0.13 * * *$ & $-0.14 * * *$ & $-0.14 * * *$ & $-0.13 * * *$ & $-0.14 * * *$ \\
\hline & {$[-3.40]$} & {$[-2.81]$} & {$[-2.74]$} & {$[-3.40]$} & {$[-2.81]$} & {$[-2.74]$} \\
\hline \multirow[t]{2}{*}{ Age } & $-0.015 * * *$ & $-0.015 * * *$ & $-0.015 * * *$ & $-0.015 * * *$ & $-0.015 * * *$ & $-0.015 * * *$ \\
\hline & {$[-4.75]$} & {$[-4.79]$} & {$[-4.81]$} & {$[-4.75]$} & {$[-4.79]$} & {$[-4.81]$} \\
\hline \multirow[t]{2}{*}{ Number of children } & $-0.025 * *$ & $-0.024 * *$ & $-0.022 * *$ & $-0.025 * *$ & $-0.024 * *$ & $-0.022 * *$ \\
\hline & {$[-2.34]$} & {$[-2.24]$} & {$[-2.14]$} & {$[-2.34]$} & {$[-2.24]$} & {$[-2.14]$} \\
\hline \multirow[t]{2}{*}{ Workplace (urban) } & 0.026 & 0.027 & 0.027 & 0.026 & 0.027 & 0.027 \\
\hline & {$[0.79]$} & {$[0.82]$} & {$[0.80]$} & {$[0.79]$} & {$[0.82]$} & {$[0.80]$} \\
\hline \\
\hline $\begin{array}{l}\text { bought at the time of } \\
\text { marriage }\end{array}$ & $\begin{array}{c}0.0080 * * * \\
\quad[2.60]\end{array}$ & $\begin{array}{c}0.0082 * * * \\
{[2.67]}\end{array}$ & $\begin{array}{c}0.0081 * * * \\
{[2.63]}\end{array}$ & $\begin{array}{c}0.0080 * * * \\
\quad[2.60]\end{array}$ & $\begin{array}{c}0.0082 * * * \\
\quad[2.67]\end{array}$ & $\begin{array}{c}0.0081 * * * \\
{[2.63]}\end{array}$ \\
\hline \multicolumn{7}{|l|}{ Level of education } \\
\hline \multirow[t]{2}{*}{ Primary } & $0.055^{*}$ & $0.056 * *$ & $0.055^{*}$ & $0.055^{*}$ & $0.056 * *$ & $0.055^{*}$ \\
\hline & {$[1.95]$} & [1.97] & {$[1.94]$} & {$[1.95]$} & [1.97] & [1.94] \\
\hline \multirow[t]{2}{*}{ Secondary } & $0.12 * * *$ & $0.12 * * *$ & $0.12 * * *$ & $0.12 * * *$ & $0.12 * * *$ & $0.12 * * *$ \\
\hline & {$[3.38]$} & {$[3.40]$} & {$[3.37]$} & {$[3.38]$} & {$[3.40]$} & {$[3.37]$} \\
\hline \multirow[t]{2}{*}{$\mathrm{SSC} / \mathrm{HSC}$} & $0.10 * *$ & $0.10 * *$ & $0.10 * *$ & $0.10 * *$ & $0.10^{* *}$ & $0.10^{* *}$ \\
\hline & {$[2.52]$} & {$[2.51]$} & [2.49] & {$[2.52]$} & {$[2.51]$} & [2.49] \\
\hline \multirow[t]{2}{*}{ Graduate } & 0.20 & 0.20 & 0.21 & 0.20 & 0.20 & 0.21 \\
\hline & {$[1.53]$} & {$[1.52]$} & {$[1.55]$} & {$[1.53]$} & {$[1.52]$} & {$[1.55]$} \\
\hline \multicolumn{7}{|l|}{ Occupation } \\
\hline \multirow[t]{2}{*}{ Salaried worker } & 0.18 & 0.18 & 0.18 & 0.18 & 0.18 & 0.18 \\
\hline & {$[1.56]$} & [1.56] & [1.57] & {$[1.56]$} & {$[1.56]$} & {$[1.57]$} \\
\hline \multirow[t]{2}{*}{ Self employed } & $0.44 * * *$ & $0.45^{* * *}$ & $0.45 * * *$ & $0.44 * * *$ & $0.45^{* * *}$ & $0.45^{* * *}$ \\
\hline & [3.69] & {$[3.70]$} & [3.69] & [3.69] & {$[3.70]$} & [3.69] \\
\hline \multirow[t]{2}{*}{ Trader } & 0.082 & 0.085 & 0.086 & 0.082 & 0.085 & 0.086 \\
\hline & {$[0.41]$} & {$[0.43]$} & {$[0.43]$} & {$[0.41]$} & {$[0.43]$} & {$[0.43]$} \\
\hline
\end{tabular}




\begin{tabular}{|c|c|c|c|c|c|c|}
\hline \multirow[t]{2}{*}{ Production food } & $0.65 * * *$ & $0.65 * * *$ & $0.66^{* * *}$ & $0.65 * * *$ & $0.65 * * *$ & $0.66^{* * *}$ \\
\hline & {$[4.66]$} & {$[4.65]$} & {$[4.75]$} & {$[4.66]$} & {$[4.65]$} & {$[4.75]$} \\
\hline \multirow{2}{*}{ Livestock Poultry } & 1.27 & 1.27 & 1.25 & 1.27 & 1.27 & 1.25 \\
\hline & {$[1.00]$} & {$[1.00]$} & {$[0.98]$} & {$[1.00]$} & {$[1.00]$} & {$[0.98]$} \\
\hline \multirow[t]{2}{*}{ Farming } & $0.60 * * *$ & $0.60 * * *$ & $0.60 * * *$ & $0.60 * * *$ & $0.60 * * *$ & $0.60 * * *$ \\
\hline & {$[6.86]$} & {$[6.85]$} & {$[6.88]$} & {$[6.86]$} & {$[6.85]$} & {$[6.88]$} \\
\hline \multicolumn{7}{|l|}{ Non-earning } \\
\hline \multirow{2}{*}{ occupation } & $0.98 * * *$ & $0.98 * * *$ & $0.99 * * *$ & $0.98 * * *$ & $0.98 * * *$ & $0.99 * * *$ \\
\hline & [13.9] & [13.9] & [13.9] & [13.9] & [13.9] & [13.9] \\
\hline \multirow[t]{3}{*}{ Income (log) } & $0.020^{*}$ & $0.023 * *$ & $0.024 * *$ & $0.020^{*}$ & $0.023 * *$ & $0.024 * *$ \\
\hline & [1.91] & {$[2.26]$} & {$[2.21]$} & [1.91] & [2.26] & {$[2.21]$} \\
\hline & $-0.088 * * *$ & $-0.092 * * *$ & $-0.090 * * *$ & $-0.088 * * *$ & $-0.092 * * *$ & $-0.090 * * *$ \\
\hline Wealth index & {$[-5.84]$} & {$[-6.08]$} & {$[-5.85]$} & {$[-5.84]$} & {$[-6.08]$} & {$[-5.85]$} \\
\hline Marital status & $0.17 * * *$ & $0.18 * * *$ & $0.18 * * *$ & $0.17 * * *$ & $0.18 * * *$ & $0.18 * * *$ \\
\hline \multirow[t]{2}{*}{ Married } & [3.89] & {$[3.88]$} & [3.96] & [3.89] & {$[3.88]$} & {$[3.96]$} \\
\hline & $-0.18 * * *$ & $-0.18 * * *$ & $-0.18 * * *$ & $-0.18 * * *$ & $-0.18 * * *$ & $-0.18 * * *$ \\
\hline \multirow[t]{2}{*}{ Widow/widower } & {$[-3.29]$} & {$[-3.23]$} & {$[-3.17]$} & {$[-3.29]$} & {$[-3.23]$} & {$[-3.17]$} \\
\hline & 0.14 & 0.14 & 0.15 & 0.14 & 0.14 & 0.15 \\
\hline \multirow[t]{2}{*}{ Divorced } & [1.09] & [1.11] & {$[1.15]$} & [1.09] & [1.11] & {$[1.15]$} \\
\hline & -0.16 & -0.16 & -0.15 & -0.16 & -0.16 & -0.15 \\
\hline \multirow[t]{2}{*}{ Separated/deserted } & {$[-1.59]$} & {$[-1.57]$} & {$[-1.49]$} & {$[-1.59]$} & {$[-1.57]$} & {$[-1.49]$} \\
\hline & $-0.16^{* * *}$ & $-0.15 * * *$ & $-0.15^{* * *}$ & $-0.16^{* * *}$ & $-0.15 * * *$ & $-0.15 * * *$ \\
\hline Constant & {$[-9.48]$} & {$[-9.88]$} & {$[-10.1]$} & {$[-9.48]$} & {$[-9.88]$} & {$[-10.1]$} \\
\hline Observations & 24,084 & 24,084 & 24,084 & 24,084 & 24,084 & 24,084 \\
\hline R-squared & 0.058 & 0.058 & 0.057 & 0.058 & 0.058 & 0.057 \\
\hline
\end{tabular}

Note: Robust t-statistics are in brackets, ${ }^{* *}, * *$ and $*$ denote 1,5 and 10 percent level of significance, respectively. All regressions include other controls, and woman fixed effects. Also, standard errors are clustered at district level. 
TABLE B13

EFFECT OF MIGRATION OF A MEMBER ON WOMEN'S EMPOWERMENT INDEX IN DIFFERENT CUT-OFF POINTS (IV RESULTS)

\begin{tabular}{|c|c|c|c|c|c|c|}
\hline \multirow[b]{2}{*}{ VARIABLES } & $(1)$ & (2) & (3) & (4) & $(5)$ & $(6)$ \\
\hline & \multicolumn{3}{|c|}{ Deprivation at least one dimension } & \multicolumn{3}{|c|}{ Deprivation at least three dimensions } \\
\hline & Overall & Internal & International & Overall & Internal & International \\
\hline Migration & $-0.11 * *$ & $-0.14 * *$ & $-0.43 *$ & $-0.11^{* *}$ & $-0.14 * *$ & $-0.43 *$ \\
\hline & {$[-1.98]$} & {$[-1.98]$} & {$[-1.90]$} & {$[-1.98]$} & {$[-1.98]$} & {$[-1.90]$} \\
\hline Age & -0.0052 & -0.0052 & -0.0052 & -0.0052 & -0.0052 & -0.0052 \\
\hline & {$[-0.97]$} & {$[-0.97]$} & {$[-0.97]$} & {$[-0.97]$} & {$[-0.97]$} & {$[-0.97]$} \\
\hline $\begin{array}{l}\text { Number of } \\
\text { children }\end{array}$ & $-0.041 *$ & $-0.041^{*}$ & -0.041 & $-0.041^{*}$ & $-0.041 *$ & -0.041 \\
\hline & {$[-1.69]$} & {$[-1.70]$} & {$[-1.64]$} & {$[-1.69]$} & {$[-1.70]$} & {$[-1.64]$} \\
\hline $\begin{array}{l}\text { Workplace } \\
\text { (urban) }\end{array}$ & $\begin{array}{l}0.052 \\
{[1.26]}\end{array}$ & $\begin{array}{c}0.051 \\
{[1.24]}\end{array}$ & $\begin{array}{c}0.053 \\
{[1.27]}\end{array}$ & $\begin{array}{c}0.052 \\
{[1.26]}\end{array}$ & $\begin{array}{c}0.051 \\
{[1.24]}\end{array}$ & $\begin{array}{l}0.053 \\
{[1.27]}\end{array}$ \\
\hline $\begin{array}{l}\text { total value of } \\
\text { asset bought at } \\
\text { the time of } \\
\text { marriage }\end{array}$ & $\begin{array}{c}0.0036 \\
{[0.70]}\end{array}$ & $\begin{array}{l}0.0039 \\
{[0.75]}\end{array}$ & $\begin{array}{l}0.0029 \\
{[0.53]}\end{array}$ & $\begin{array}{l}0.0036 \\
{[0.70]}\end{array}$ & $\begin{array}{l}0.0039 \\
{[0.75]}\end{array}$ & $\begin{array}{l}0.0029 \\
{[0.53]}\end{array}$ \\
\hline $\begin{array}{l}\text { Level of } \\
\text { education }\end{array}$ & $\begin{array}{c}0.083 * * * \\
{[5.55]}\end{array}$ & $\begin{array}{c}0.083 * * * \\
{[5.53]}\end{array}$ & $\begin{array}{c}0.083 * * * \\
{[5.56]}\end{array}$ & $\begin{array}{c}0.083 * * * \\
{[5.55]}\end{array}$ & $\begin{array}{c}0.083 * * * \\
{[5.53]}\end{array}$ & $\begin{array}{c}0.083 * * * \\
{[5.56]}\end{array}$ \\
\hline Occupation & $\begin{array}{c}0.13^{* * *} \\
{[11.8]}\end{array}$ & $\begin{array}{c}0.13^{* * *} \\
{[11.9]}\end{array}$ & $\begin{array}{c}0.13^{* * *} \\
{[11.8]}\end{array}$ & $\begin{array}{c}0.13^{* * *} \\
{[11.8]}\end{array}$ & $\begin{array}{c}0.13 * * * \\
{[11.9]}\end{array}$ & $\begin{array}{c}0.13 * * * \\
{[11.8]}\end{array}$ \\
\hline Income (log) & $\begin{array}{l}0.0081 \\
{[0.45]}\end{array}$ & $\begin{array}{l}0.0075 \\
{[0.42]}\end{array}$ & $\begin{array}{c}0.0090 \\
{[0.51]}\end{array}$ & $\begin{array}{l}0.0081 \\
{[0.45]}\end{array}$ & $\begin{array}{l}0.0075 \\
{[0.42]}\end{array}$ & $\begin{array}{c}0.0090 \\
{[0.51]}\end{array}$ \\
\hline
\end{tabular}




\begin{tabular}{|c|c|c|c|c|c|c|}
\hline \multirow{2}{*}{ Wealth index } & -0.059 & -0.060 & -0.058 & -0.059 & -0.060 & -0.058 \\
\hline & {$[-1.38]$} & {$[-1.39]$} & {$[-1.34]$} & {$[-1.38]$} & {$[-1.39]$} & {$[-1.34]$} \\
\hline \multirow[t]{2}{*}{ Marital status } & $-0.089 * * *$ & $-0.089 * * *$ & $-0.088 * * *$ & $-0.089 * * *$ & $-0.089 * * *$ & $-0.088 * * *$ \\
\hline & {$[-2.80]$} & {$[-2.81]$} & {$[-2.80]$} & {$[-2.80]$} & {$[-2.81]$} & {$[-2.80]$} \\
\hline Observations & 23,423 & 23,423 & 23,423 & 23,423 & 23,423 & 23,423 \\
\hline R-squared & 0.03 & 0.03 & 0.03 & 0.03 & 0.03 & 0.03 \\
\hline First stage F-stat & 698 & 356 & 31.5 & 698 & 356 & 31.5 \\
\hline Sargan statistics & 0.098 & 0.085 & 0.16 & 0.098 & 0.085 & 0.16 \\
\hline
\end{tabular}

142 Journal of Business Diversity Vol. 21(2) 2021 